\title{
History of the Chivor EMerald Mine, PART I (1880-1925): From ReDISCOVERY To Early Production
}

Karl Schmetzer, Gérard Martayan, and Jose Guillermo Ortiz

The history of the Chivor emerald mine in Colombia is rife with legend and adventure. The tale traces from early exploitation by indigenous people, to work by the Spanish in the sixteenth and seventeenth centuries, to 200 years of abandonment and jungle overgrowth. The story then picks up with rediscovery near the turn of the twentieth century by the Colombian mining engineer Francisco Restrepo using clues from a historical manuscript. Still the saga continued, with repeated shortages of investment funds driving multiple ownership changes and little progress toward mining the largely inaccessible deposit. The German gem merchant Fritz Klein, in cooperation with Restrepo, pursued limited mining activities with a small number of workers for a few months prior to the outbreak of World War I. After the war, the American company Colombian Emerald Syndicate, Ltd., took ownership, and mining operations resumed under the new leadership. Ownership changed yet again in the 1920s, followed by multiple cycles of expanding and shrinking mining activity, interrupted by completely unproductive periods.

T he foregoing outline of the story, as presently known, has been drawn largely from three books authored by individuals who led the mining activities at Chivor during different eras: German gem merchant Fritz Klein, South African mining engineer Peter W. Rainier, and American gem hunter and buyer Russell W. Anderton. All three men wrote in a style to highlight the adventurous nature of the work. Klein's memoir covered the period from approximately 1911 to 1923 and was initially published in 1941, with a slightly updated version released in 1951. Rainier's narrative chronicled from the second half of the 1920s to the early 1930s and was printed in 1942. Anderton's work, coming to press in 1953 in the United States and 1954 in the United Kingdom, recounted activities of the late 1940s and early 1950s.

The events presented in the three books have, since their respective publications, found their way in numerous variations into historical articles or descriptions as well as gemological, mineralogical, or geological papers. ${ }^{1}$ The rediscovery of Chivor by Francisco Restrepo (figure 1) and the clues that motivated his search have been a particularly popular topic. In gen-

See end of article for About the Authors and Acknowledgments.

Gems \& Gemologr, Vol. 56, No. 1, pp. 66-109,

http://dx.doi.org/10.5741/GEMS.56.1.66

(C) 2020 Gemological Institute of America eral, the events described by Klein, Rainier, or Anderton have been accepted as facts in the literature, and only Klein's description and dating of the rediscovery

\section{In Brief}

- After 200 years of abandonment, the modern history of the Chivor emerald mine began with rediscovery by the Colombian mining engineer Francisco Restrepo in the 1880s.

- After several trials to sell the mine by the Colombian owners, in 1912 German gem merchant Fritz Klein then joined Restrepo in further efforts, but Klein's attempts to complete a purchase with a group of German investors were thwarted by the outbreak of World War I.

- After the war, an American company, the Colombian Emerald Syndicate, Ltd., took ownership in late 1919.

- Although operations resumed under the new leadership, lasting success was not to be found, and the Colombian Emerald Syndicate entered bankruptcy proceedings in 1923.

by Restrepo have on occasion been questioned or discussed. ${ }^{2}$ It has been noted that Klein's time frame for the rediscovery clearly differs from that presented in

${ }^{1}$ See, e.g., Weldon et al., 2016, for a recent example.

${ }^{2}$ See, e.g., Sinkankas, 1981; Moore and Wilson, 2016. 


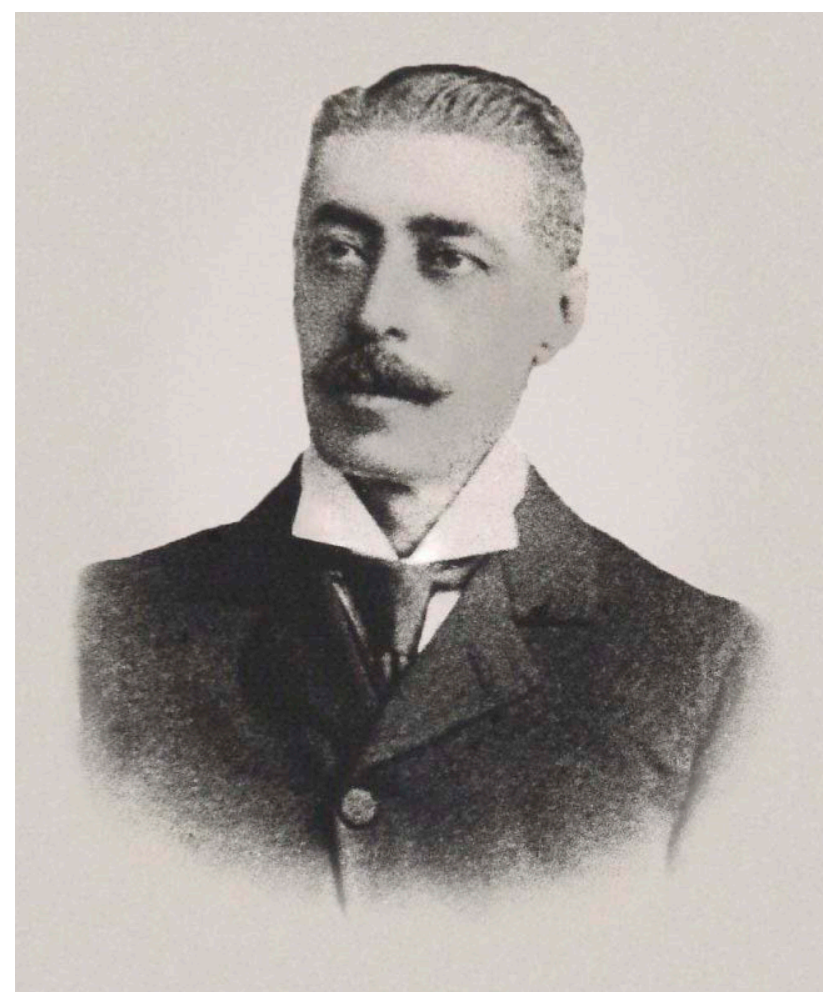

Figure 1. Francisco Daniel Restrepo Escobar, circa 1906. Restrepo began his career at gold and silver mines in the Colombian states of Antioquia and Tolima in the 1870s and 1880s. He is credited with rediscovery of the Chivor emerald mines, an event that evidence also places in the 1880s. The early 1900s found him at gold mines in Ecuador and then leading operations at the Muzo emerald mines. In the 1910s, he returned to Chivor, where he would cooperate with German miner Fritz Klein to find investment funding for the project. Courtesy of Eduardo Restrepo Ortega.

other publications. This discrepancy, in turn, provided the impetus for the present project, aiming not only to clarify this inconsistency but also, more broadly, to probe the trustworthiness of the purported historical "facts" recounted by Klein, Rainier, and Anderton.

The focus was on locating contemporaneous primary documents, such as original letters and contracts, that could elucidate events underlying the oft-repeated descriptions. Beginning with an emphasis on the period covered by Klein (figure 2), the search was subsequently augmented to consider the record from the 1880s to the 1970s. In summary, the project endeavored to present a comprehensive survey of Chivor's history from its rediscovery to the second half of the twentieth century, based principally upon primary contemporaneous materials, divided into two parts. The first installment of this work covers the period from the 1880s to 1925 .

\section{SOURCES}

The search for contemporaneous materials spanned Europe, South America, and North America, as key figures in the story hailed from or worked in Germany, the United Kingdom, Colombia, and the United States. These primary documents were compared with the known literature on the topic. Full citations for the principal existing publications consulted are summarized in the reference list. Other primary documents, such as governmental and judicial reports and decrees that may appear in broader compendiums, archived contracts, business records, newspaper articles, personal correspondence, etc., are identified to the extent feasible in the footnotes, along with brief citations to publications included in the reference list. Direct quotations from original sources in German or Spanish were translated for purposes of this publication.

Investigations began with the German Federal Archive (Bundesarchiv) and the Historical Archive of the German Ministry of Foreign Affairs (Auswärtiges Amt), both in Berlin. Stored in these repositories

Figure 2. Portrait of the gem merchant Fritz Klein by the artist Rudolf Wild, Idar-Oberstein, Germany, in the mid-1930s. At that time, Klein was engaged in writing the 1941 book describing his earlier adventures searching for new gem deposits in South America; a highlight is the saga of his engagement with the Chivor emerald mine in Colombia. Courtesy of Wolf D. Unger.

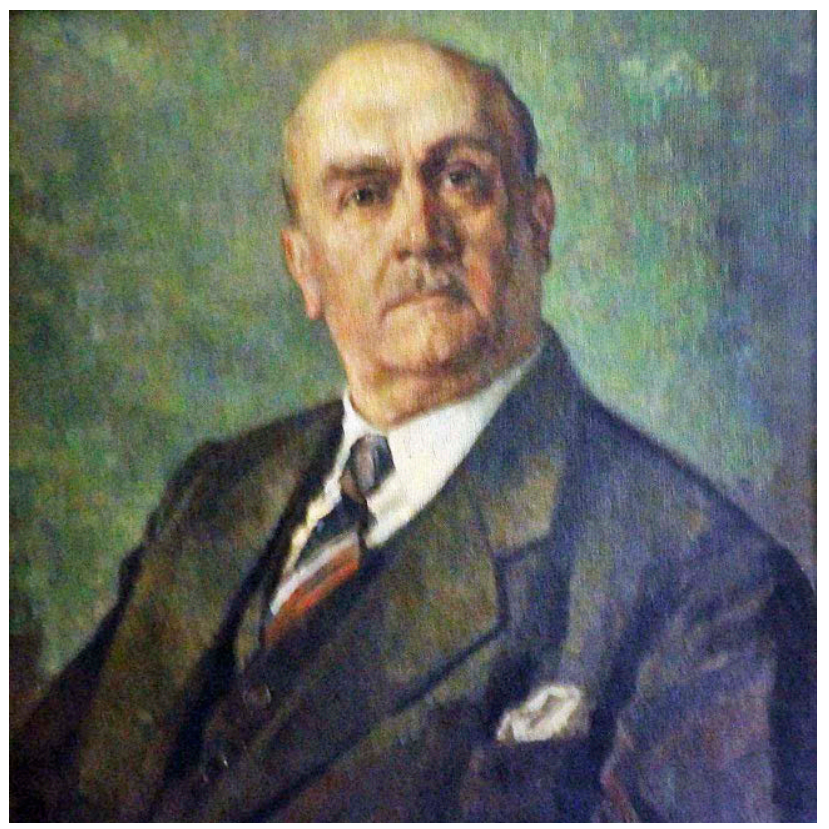


were original documents or copies thereof involving the emerald mines in Colombia, largely in materials generated during relevant periods by the German Ministry of Foreign Affairs in Berlin and the German Residency (essentially equivalent to an embassy) in Bogotá. ${ }^{3}$ Of a similar nature and also held in Europe were correspondence and related materials in the collections of the Kew National Archives in London, derived from the United Kingdom's Foreign Office.

Principal Colombian materials were found in the form of government publications printed, typically anonymously, in the "Diario Oficial (Colombia)," in the "Gaceta Judicial (Colombia)" of the Corte Suprema de Justicia (Supreme Court), and in the reports of ministries or other government offices. These included legislative texts, decrees, governmental or judicial pronouncements, and statements on petitions and complaints. The Archivo General de la Nación (Colombia) in Bogotá further yielded notarial acts (escrituras) and attachments reflecting mine title transfers, sales of shares between various shareholders, and agreements shedding light on the ongoing fluctuations in Chivor ownership and related events. ${ }^{4}$

Europe and the Americas also proved to be sources of collections of a more personal nature, with notable materials being found both in the University Library Freiburg (Universitätsbibliothek Freiburg) archives $^{5}$ and in the private holdings of family members. For example, Francisco Restrepo's grandson Eduardo Restrepo Ortega held family documents from the late 1880 s to the early 1920s describing many aspects of his grandfather's role with Chivor. Likewise, descendants of Fritz Klein and his brother August, who worked together at Chivor between 1912 and 1914, were in possession of original photos from Colombia and copies of letters written by family members between 1907 and 1920. Unfortunately, the original manuscript for Klein's 1941 book was not located by the present authors. Contributions of this nature from relatives of many key players were instrumental, and their importance cannot be overstated. ${ }^{6}$

Even online resources added to the available contemporaneous data. Noteworthy in this regard were digitized compilations of records detailing transit of persons, such as passenger lists maintained by the United States Immigration Office in New York and by offices in Hamburg and Bremen, Germany, and in Tilbury, London, United Kingdom. ${ }^{7}$ Those records detailed information that could incorporate departures and arrivals through national borders, starting points, destinations, and, most importantly, specific dates to help establish or corroborate event time frames. Similarly insightful were digital archives of newspapers across the United States, which enabled view of events as presented to the public in the early twentieth century.

\section{LOCATION}

The Chivor mining area is located northeast of Colombia's capital Bogotá, in proximity to the present-day small municipalities of Somondoco and Almeida to the north and Gachalá and Ubalá to the southwest (figure 3). In the early decades of twentieth century, the nearest community of sufficient size to host a telegraph office was Guateque, accessible via a one-day journey by horse.

The main emerald mines are situated south of the town of Chivor, founded in 1930, between the valleys of the Río Sinai and the Río Rucio, the latter of which flows into the Río Guavio. (The two valleys are alternatively referred to as Quebrada Sinai and Quebrada de las Minas, quebrada meaning "gorge" or "breaking reef" in Spanish.) North of the Chivor area are the Río Somondoco and the Río Garagoa. Chivor is now positioned between two large dams that were built in the second half of the twentieth century, the Embalse de Chivor (Chivor Dam) and the Embalse del Guavio (Guavio Dam). The Río Garagoa runs toward the Embalse de Chivor and south of the dam is also called the Río Bata, which in turn flows into the Río Guavio.

${ }^{3}$ In the German Federal Archive (Bundesarchiv) in Berlin, pertinent material was found in file R901, archive numbers 1303, 1304, and 1305, all covering the years 1911 to 1920. In addition, file R901, archive number 81190 , contained a mining report from 1913 by a member of the German Residency in Bogotá. In the Historical Archive of the German Ministry of Foreign Affairs (Auswärtiges Amt), also in Berlin, principal relevant files were designated RAV Bogotá Volume 50 (now 136) and R Volume 91809, covering the years 1914 to 1936. ${ }^{4}$ Most relevant at the Archivo General de la Nación (Colombia) in Bogotá were several notarial acts (escrituras) designated herein by escritura number and date. Also useful was a file entitled "Minas de Esmeraldas" incorporating materials from 1905 to 1917, collected by the Ministerio de Relaciones Exteriores. Similarly instructive was the file "Joaquin Daza B.," Volume "Propuestas Minas 99," Ministerio de Industrias, Departamento de Minas y Petróleos, which contained documents covering 1929 to 1954 and detailing mine boundaries and history.

${ }^{5} \mathrm{Held}$ at the University Library Freiburg ((Universitätsbibliothek Freiburg) was a collection of documents related to Prof. Robert Scheibe, a geologist involved in scientific investigations at and evaluation of Chivor, as detailed below.

${ }^{6}$ See the acknowledgments for additional indication of the scope of such contributions.

${ }^{7}$ MyHeritage.com, Ancestry.com, and Ancestry.de databases. The New York passenger lists record the arrival of United States or foreign citizens, the Hamburg and Bremen passenger lists record departures from Germany, and the London passenger lists record departures of British citizens from the port of Tilbury. 


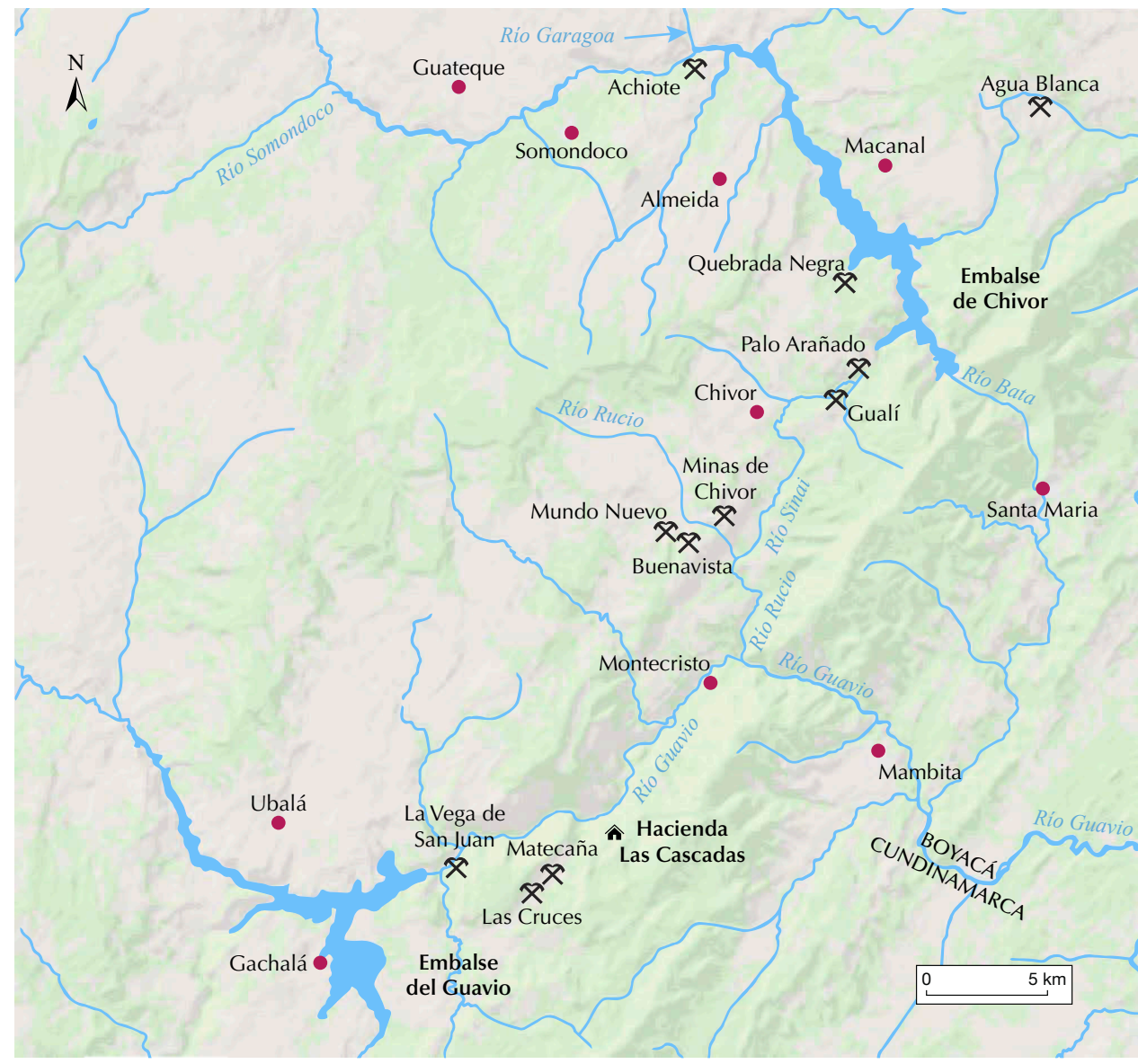

Figure 3. Map showing the location of the Chivor emerald mines, south of the towns of Somondoco and Almeida and northeast of Gachalá and Ubalá, in the Departamento de Boyacá, Colombia. The area is now located between two dams, Embalse de Chivor and Embalse del Guavio, that were built in the second half of the twentieth century. The other emerald mines in the departments of Boyacá and Cundinamarca were discovered and exploited in the twentieth century, subsequent to the rediscovery of Chivor.

The Chivor mining area currently consists of many tunnels and galleries worked employing industrial methods, with production yielding large quantities of gem-quality emeralds. ${ }^{8}$ This scenario presents a marked contrast to the harsh working conditions and difficulties encountered in the first half of the twentieth century.

\section{PRE-NINETEENTH CENTURY HISTORY OF THE SOMONDOCO (CHIVOR) EMERALD MINES}

Beginning in early April 1536, a Spanish military expedition was conducted under the leadership of conquistador Gonzalo Jiménez de Quesada into the region that later became Nueva Granada (the New Kingdom of Granada, encompassing approximately the territory of modern Colombia)..$^{9}$ The journey embarked from the Atlantic coastal city of Santa Marta, and by December 1536, the expeditionary group had begun to cross the Andes Mountains. They arrived in the territory of the indigenous Muisca in March 1537. As they traveled south, the Spanish soldiers encountered emeralds in the region, and Quesada ordered the captain Pedro Fernández Valenzuela to search for the mines. Valenzuela departed from Que- sada's camp in late May or early June 1538 and proceeded as reported in a letter from 1539:

Valenzuela departed with several others, and after six days they arrived at the said mines, where he and the other Spaniards with him, watched the Indians extract the emeralds from below the ground, and they witnessed such strange new things. The mines are located roughly fifteen leagues from the Valley of the trumpet, in a very high and sparse mountain range. It appears that the emeralds are extracted from an area about one league in size. The lord of the mines is a very principal Indian by the name of Somyndoco [Somondoco]. He is sovereign over many vassals and settlements, and his private residence is located three leagues' distance from the mines.... Those who went on the discovery of the emerald mines said that from the mines they could see some great planes [11anos], so marvelous that nothing like them ever had been seen. On hearing this news, Jiménez moved the camp closer to the mines.... ${ }^{10}$

A similar account of the discovery of the ancient Somondoco emerald mines appeared, with minor

${ }^{8}$ Fortaleché et al., 2017.

${ }^{9}$ Francis, 2007.

${ }^{10}$ Letter from two Spanish captains, July 8, 1539, Archivo General de Indias, Seville, Spain, as translated and published by Francis, 2007. One league was equivalent to $5.57 \mathrm{~km}$. See Lane, 2010. 
variations, in all historical descriptions of the conquest of Nueva Granada penned by sixteenth- and seventeenth-century Spanish authors. Examples include those by Fray Pedro de Aguado, Fray Pedro Simón, and Lucas Fernández de Piedrahita.

In the following decades, the mines referred to as Somondoco in contemporaneous Spanish texts were worked with limited success, although a portion of the emerald mining activity was diverted to the Muzo deposits after their discovery to the northwest in the 1560s. ${ }^{11}$ Exploitation at Somondoco continued under various owners and lessees ${ }^{12}$ into the 1670s, with the last known documentary evidence of activity dated from 1672 to $1675 .^{13}$

Beyond that time, there exists no known record of further activity at the mines, nor is there any report detailing why the mines were abandoned. While the literature refers to an order to close the mines issued by the Spanish monarch Carlos II /reigning 1665-1700), , ${ }^{14}$ such an order has never been proven and could not be located despite recent extensive research. ${ }^{15}$ By 1772 it was noted that the mines of Somondoco were deserted and that nothing more than some vague remains of the old workings could be found. ${ }^{16}$ Thus, over the course of more than 200 years beginning in the 1670s, any detailed knowledge about the location of the Somondoco emerald mines was essentially lost.

\section{REDISCOVERY OF CHIVOR}

The rediscovery of the historical mines of Somondoco, henceforth known primarily as the Chivor mines, has long been attributed to the Colombian mining engineer Francisco Daniel Restrepo Escobar ${ }^{17}$ (1855-1914). Restrepo was born in Rionegro, Antioquia, Colombia, and was involved in the mines of Antioquia during his younger years. ${ }^{18}$ By the early 1880s, he had transferred his attention to the neighboring state of Tolima, where he worked as a prospector and mine production manager. At the time, mineral deposits in Antioquia were considered nearly exhausted, while Tolima was viewed as having strong potential for alluvial gold and silver mines. Restrepo's activities in Tolima involved searching for lost mines from the colonial era as well as discovering new mines. During the first half of the 1880s, at least a portion of his work was done in association with the Compañía Minera del Tolima (not to be mistaken with the British Tolima Mining Company, Limited), ${ }^{19}$ but from the mid-1880s Restrepo also worked in partnership with Luis Correa. From 1885 to 1887 , numerous new deposits, mostly gold and silver mines, were discovered and registered with the government (to establish claims and valid mining titles) by both Restrepo and Correa, either alone or together. ${ }^{20}$ Evidence of Restrepo's mining activities in Tolima extends to the end of the decade, with records showing mine tax payments and sales transactions for several gold and silver mines as late as $1889 .{ }^{21}$ Conversely, records for the following two decades are silent in that regard, but those from 1910 reflect that Restrepo was still holding mining titles in the area, together with several partners. ${ }^{22}$ Meanwhile, as of 1891 Restrepo had apparently resumed efforts back in Antioquia as well. ${ }^{23}$

\footnotetext{
${ }^{11}$ Lane, 2010.

${ }^{12}$ Canova, 1921.
}

${ }^{13}$ Slave labor at the mines was described in a document from 1672 (Kris Lane, pers. comm., 2018). Litigation in 1672 involving Somondoco mining rights has also been reported (Canova, 1921). Several additional years of activity are supported by archival material from the second half of the seventeenth century in the file "Minas-Boyacá," SC 38, 1, D10, Archivo General de la Nación (Colombia).

${ }^{14}$ Martin de Retana, 1990.

${ }^{15}$ Kris Lane, pers. comm., 2018.

${ }^{16}$ Moreno, 1772, published 1870.

${ }^{17}$ Commonly referred to as Francisco Restrepo, the names Francisco Restrepo Escobar or Francisco Restrepo E. also appear in official documents, with his signature on notarial acts taking the latter form. His year of birth is similarly ambiguous. A death certificate indicates 1853, while passenger lists reflecting his departure from Hamburg and subsequent arrival in New York in November 1913 give an age of 62, implying that he was born in 1851. File F. Restrepo, Hamburger Passagierlisten (list of passengers departing from Hamburg), November 1913, Ancestry.de; File F. Restrepo, List or Manifest of Alien Passengers for the United States Immigration Officer at Port of Arrival, New York, November 1913, Ancestry.com. However, the date 1955 was provided by his grandson. Eduardo Restrepo Ortega, pers. comms., 2018, 2019.

${ }^{18}$ Aguilar, 1884.

${ }^{19}$ Martínez Covaleda and Martínez Covaleda, 1996; Moreno Calderón, 2011.

${ }^{20}$ Diario Oficial (Colombia), 23, No. 7208 (1887), pp. 1194-1195; Esquivel Triana, 2001; Quintero and Centeno, 2007.

${ }^{21}$ Informe presentado al Congreso de la República en sus sesiones ordinarias de 1890 por el Ministro de Hacienda, Segunda Parte - Informes de los administradores departamentales de Hacienda, pp. 219-320; Skinner, 1891-1892; Escritura 556, May 25, 1899, Notaria 3, Archivo General de la Nación (Colombia).

${ }^{22}$ The Compañía de Minas de Los Alpes holding these mining titles was formed in 1910 and reorganized in 1916. Escritura 148, February 3, 1910, Notaria 2, Escrituras 944 and 955, May 2, 1916, Notaria 2, Archivo General de la Nación (Colombia). Restrepo was also involved in the late 1800s and early 1900s in ventures unrelated to mining. For example, through an administrator he operated two haciendas in the district of Paime, south of Muzo, named Santa Teresa and San Luis, which were abandoned during the Colombian civil war. After the war, in 1902, he was active in the coffee trade. Gaceta Judicial (Colombia), 20 (1911), pp. 49-57.

${ }^{23}$ Brissón, 1899. 


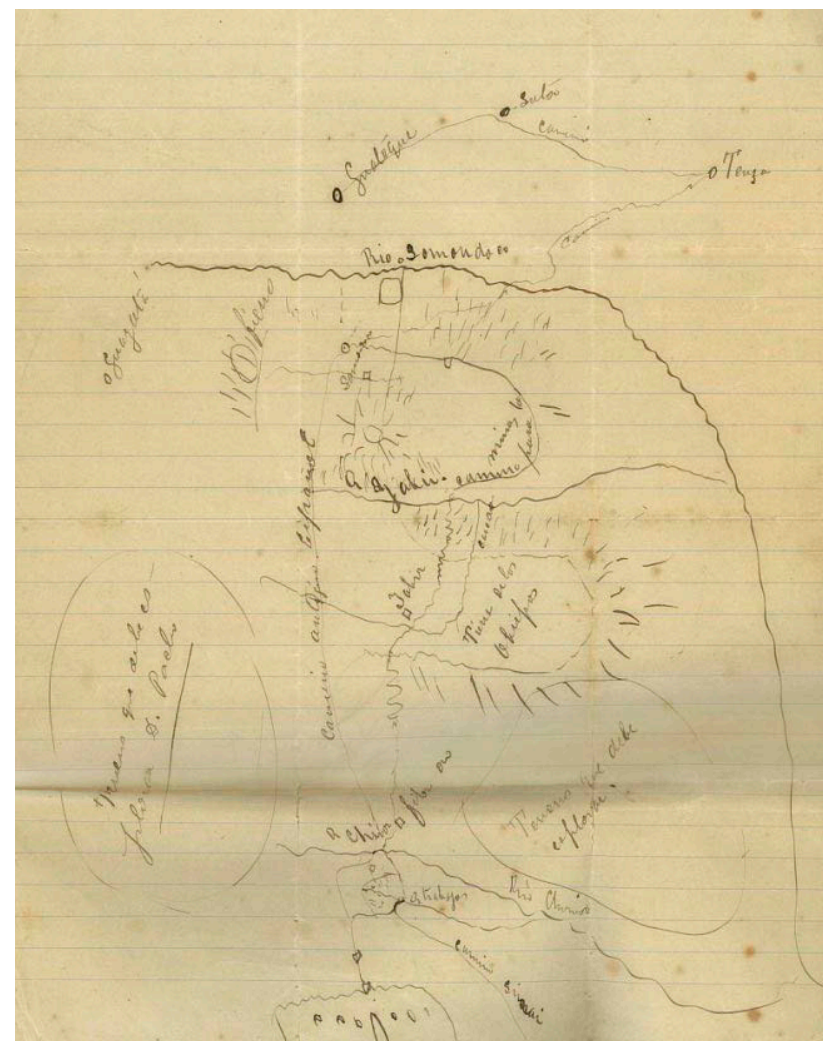

Figure 4. Undated hand-sketched map, from a collection of original documents in the possession of Francisco Restrepo's grandson, of the region south of the town of Guateque and the Río Somondoco in Colombia, incorporating notations regarding already located mines and promising areas for search. Courtesy of Eduardo Restrepo Ortega.

The foregoing regions, however, did not constitute Restrepo's sole focus. The emerald mines in Boyacá designated Chivor 1 and Chivor 2 were registered with the government in 1889, and Restrepo was clearly involved in the process, which comprised multiple steps. ${ }^{24}$ The first step in applying for the titles (acta de aviso) was undertaken by Miguel Perilla in the names of Restrepo, Enrique González, ${ }^{25}$ Bernardo Escovar, ${ }^{26}$ and Núñez \& Compañía ${ }^{27}$ in January 1889. The application was then granted and published in March 1889. Thereafter, at a date and under circumstances not otherwise elucidated, title ownership apparently transferred from the original four applicants to Restrepo and Correa, who were recognized as the owners in documentation from 1896 , seven years later. ${ }^{28}$

Nonetheless, two critical aspects regarding Restrepo's underlying rediscovery of the Chivor mines are fraught with discrepancy and ambiguity: the date of the rediscovery and the source of the information on which he relied.
As to the date, Klein (1941) estimates 1903 to 1904. Conversely, Spanish texts place this event in 1896 or even as early as 1888 to $1889,,^{29}$ and Englishlanguage texts mostly quote $1896 .^{30}$ The English texts primarily refer to Latham (1911), but that work offers no corroborative reference to support the 1896 date given. Domínguez $z^{31}$ (1965), the most detailed Spanish textbook on the history of Colombian emeralds, cites a limited number of geological studies but does not associate historical events with any primary source. The Spanish publication by Martin de Retana (1990) chronicles historical events, but the individual facts are neither consistent nor correlated with the references cited. German authors, in most cases, follow the version and dates given by Klein (1941).

No direct written communication by Restrepo describes his search; the only known tangible evidence of his efforts consists of three rough hand-sketched maps, all undated, found in his personal papers (e.g., figure 4). These merely depict selected areas between Río Somondoco and Río Guavio and mark the locations of already discovered mines and promising sites for search. Nonetheless, a report authored by Klein in 1913 and notes by Prof. Robert Scheibe from 1914 offer verification from contemporaneous primary sources. As will be detailed below, both Klein and the geologist Scheibe spent time with Restrepo at Chivor. In the report by Klein, which was an "ex-

${ }^{24}$ Escritura 201, February 13, 1899, and attachments, Notaria 3, Archivo General de la Nación (Colombia); letter from a department of the Ministerio de Hacienda in Tunja, Colombia, to the Ministerio de Industrias, 1930, file "Joaquin Daza B.," Volume "Propuestas Minas 99," Ministerio de Industrias, Departamento de Minas y Petróleos, Archivo General de la Nación (Colombia).

${ }^{25}$ Enrique González served as director of operations at the Muzo and Coscuez emerald mines in Colombia from 1886 to 1901, first on behalf of Lorenzo Merino and later on behalf of the English Mining Syndicate, Limited. Gaceta Judicial (Colombia), 15 (1901), pp. 169-173; González, 1911

${ }^{26} \mathrm{Also}$ referred to as Bernardo Escobar in several documents, with his signature on notarial acts generally taking the form Escovar (used hereinafter).

${ }^{27}$ The background of Núñez \& Compañía is vague; subsequent to the reference in the 1889 application, an entity by that name is identified as having been founded in 1895 by four brothers. Escritura 1286, November 30, 1895, Notaria 1, Archivo General de la Nación (Colombia).

${ }^{28}$ Escritura 201, February 13, 1899, and attachments, Notaria 3, Archivo General de la Nación (Colombia).

${ }^{29}$ Domínguez, 1965; Martin de Retana, 1990; Calvo Perez, 1992.

${ }^{30}$ Latham, 1911; Pogue, 1917; Canova, 1921.

${ }^{31}$ Rafael A. Domínguez was head of the financial administration (Interventor de Salinas y Esmeraldas) of the Ministerio de Minas y Petróleos in Bogotá. Memoria del Ministro de Minas y Petróleos al Congreso de 1963 (1963), p. 26. 
posé" 32 likely written for potential investors, 1882 was given as the date when indications of the mine's location were found, and 1885 was noted as when the old tunnels worked centuries ago were rediscovered. Scheibe's personal notes ${ }^{33}$ discussed the boundaries of the two mines Chivor 1 and 2 in connection with "the work that Restrepo did in the 80s of the last century." Thus, primary and secondary documentation places the search for the lost mines and their rediscovery in the 1880s.

The nature of the collaboration between Restrepo and Correa in the rediscovery remains obscure, ${ }^{34}$ but a 1911 letter from Correa to Restrepo lends a degree of corroboration to the 1880s timing. Although the correspondence makes no direct mention of Chivor, it does discuss possible future cooperative ventures and refers back to an event in 1885 when they were "extremely lucky." 35

Turning to the question of the source of the clues on which Restrepo relied, it is generally reported that he was guided by hints found in historical manuscripts, but further details differ widely. In nineteenth-century descriptions of Colombian history, Acosta (1848), Plaza (1850), and Groot (1869) recounted the expedition of Valenzuela in 1538 and indicated that from the Somondoco mines, or on the journey thereto, great plains (1lanos) were visible to the east. Other nineteenth-century publications offered even somewhat misleading information such as "nine leguas [leagues] south-south-east of Guateque, close to the cascade of Nagar." ${ }^{\prime 36}$

With respect to Spanish authors from the colonial period, the description of Colombia's history by Lucas Fernández de Piedrahita, first published in

\footnotetext{
${ }^{32}$ Exposé der Smaragdmine "El Chivor" by Fritz Klein, undated, 16 pp., received by the German Ministry of Foreign Affairs September 13, 1913, and preserved in the German Federal Archive. A portion of this document was translated and published in English by Canova (1921).

${ }^{33}$ Prof. Robert Scheibe collection, University Library Freiburg.

${ }^{34}$ Likewise minimal is information about Luis Correa's life after the Chivor rediscovery. He did, however, remain involved in the emerald business, serving for example as Inspector de las minas de esmeraldas de Muzo \& Coscuez. Diario Oficial (Colombia), 42, No. 12693 (1906), p. 630.

${ }^{35}$ Letter from Luis Correa, March 15, 1911, to Restrepo.

${ }^{36}$ Ancizar, 1853; Schuhmacher, 1875. The cascade of Nagar was located close to Macanal but is now covered by the Chivor Dam. Enciclopedia Universal Ilustrada Europeo-Americana, 1931; Geografía económica de Colombia, 1936. This locality would be about $15 \mathrm{~km}$ too far northeast from the present Chivor mines; see also figure 3.

${ }^{37}$ Robinson López, Biblioteca Nacional de Colombia, Bogotá, pers. comm., 2017.

${ }^{38}$ Fals-Borda, 1955; Friede, 1964.
}

Antwerp in 1688, was reprinted in Bogotá in 1881 and, as a consequence, could have been readily available to Restrepo at the beginning of the 1880s.

The historical treatise by Fray Pedro Simón, one of the most prominent authors of the Spanish conquest, has frequently been mentioned as the original source for Restrepo's information. Only the first volume of this five-volume series was published in the seventeenth century, with the complete set edited and printed in Bogotá from 1882 to 1892. The second volume, which contained the description of Valenzuela's 1538 expedition to Somondoco, was published in 1891 from a handwritten manuscript preserved in the Biblioteca Nacional de Colombia (National Library of Colombia) in Bogotá. The original manuscript had been prepared by Simón in the 1620s, and that manuscript or a copy of it had been available and accessible at the national library since 1852 , when it came into the collection from the private library of Joaquin Acosta. ${ }^{37}$

Fray Pedro de Aguado, the sixteenth-century chronicler of the Spanish conquest of Colombia and Venezuela, has also been cited as a possible source for Restrepo's information. Aguado's treatise "Recopilación Historial" was never published during the colonial period. ${ }^{38}$ The handwritten first volume, concerning Colombia, was discovered in Madrid by Acosta in 1845 and briefly mentioned in his history of Nueva Granada published in 1848. The handwritten manuscript itself, copied in the early years of the twentieth century, was published in Bogotá in 1906. These facts indicate that Aguado's treatise on Colombia was most likely not available to Restrepo in the 1880s.

In summary, the only known information available to guide Restrepo's journey was the vague hint about the llanos being visible from the Chivor mining region (figure 5) and perhaps some approximate indication of distance from the town of Somondoco. This information would have been accessible to him from several sixteenth- and seventeenth-century authors and as repeated in nineteenth-century historical texts. The present authors are aware of neither further handwritten manuscripts from sixteenth- or seventeenth-century historians nor any other detailed accounts or maps that might have identified the location of the ancient Somondoco mines.

\section{MINING TITLE TRANSFERS, MINING COMPANY FORMATION, AND EARLY YEARS (1896-1910)}

As previously noted, titles to mines designated Chivor 1 and Chivor 2 were registered in 1889, and by 1896 


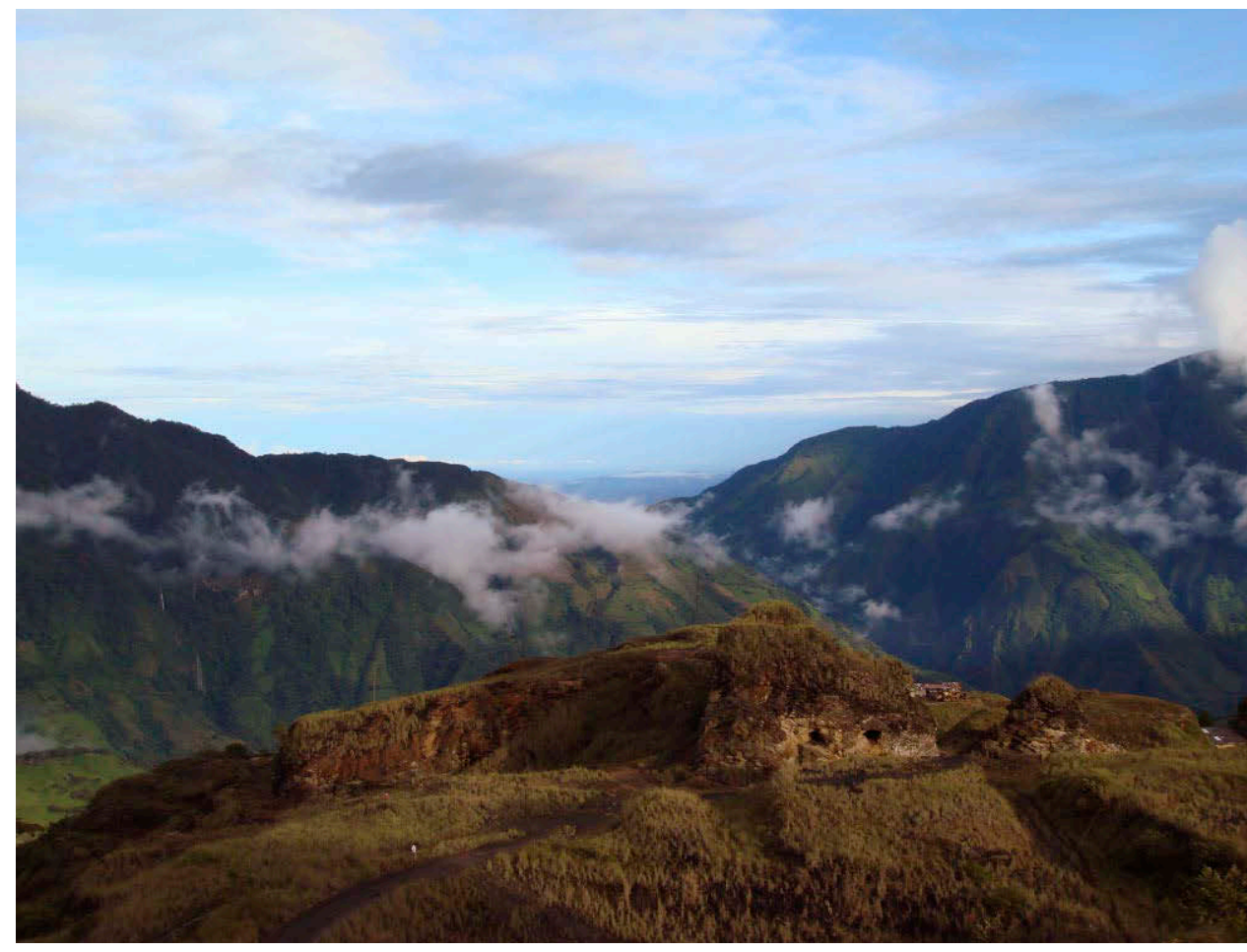

Figure 5. In all the sixteenth- and seventeenth-century texts that describe the Spaniards' discovery of the Chivor emerald mines-named Somondoco at that time-it was mentioned that great plains (llanos) were seen from the mines or on the way to the mines in a view to the east. Courtesy of Kris Lane, Tulane University.

Restrepo and Correa were recognized as the owners. The registration was made in accordance with the Colombian mining law then in effect, which stipulated that a gem mine could not exceed one square kilometer in size (Law No. 38 of 1887, Article 2). ${ }^{39}$ The Chivor emerald mines thus consisted of two contiguous areas of one square kilometer each and were not otherwise split or subdivided during the relevant period. Any mining in the region employed open-pit methods, as was generally the case in Colombia prior to 1930. Although the Chibcha and Spanish in prior centuries may have attempted to build tunnels, even those extended only a few meters into the mountains.

At the Chivor claims, no mining activity took place for several years after registration. The 1891 annual taxes for the two mines were paid by Correa, ${ }^{40}$ but no further payments are known. As a result, Chivor 1 and 2 were declared "abandoned" on August 23,1896 , on account of an absence of operations in the seven years since the registration and a failure to pay taxes on the mines since $1891 .{ }^{41}$ Attendant legal formalities led to the titles being transferred from Correa and Restrepo to González on February 16, $1898 .{ }^{42}$

Later in 1898, a mining entity was formed as a joint stock company between González, Restrepo, Escovar, and Núñez \& Compañía, but without Correa, and the Chivor 1 and 2 mining titles were transferred from González to that company. ${ }^{43}$ Share distribution at formation was as follows: 40 shares for Restrepo, 20 for González, 20 for Escovar, and 20 for Núñez \& Compañía. The latter two were to act as investors, while Restrepo and González, both of whom had mining experience, were to continue exploration and to start practical operations. The company later became known as the Compañía de las Minas de Esmeraldas de Chivor, ${ }^{44}$ or, in certain materials, Sociedad Ordinaria de las Minas de Chivor. For clarity, the different companies involved in the Chivor emerald business are listed in table 1.

In 1898 and likely into the next year, Restrepo spent time at the mine, mainly supervising restoration and construction of a water supply and irrigation system. These efforts aimed to evaluate the potential of the deposit and to prepare the mine for visits by possible investors, looking for veins and samples in

\footnotetext{
${ }^{39}$ Bullman, 1892.

${ }^{40}$ Diario Oficial (Colombia), 28, No. 8842 (1892), p. 819.

${ }^{41}$ Escritura 201, February 13, 1899, and attachments, Notaria 3, Archivo General de la Nación (Colombia).

${ }^{42}$ Escritura 201, February 13, 1899, and attachments, Notaria 3,

Archivo General de la Nación (Colombia); Report by Dr. Antonio José Cadavid, March 18, 1913, Historical Archive of the German Ministry of Foreign Affairs.

${ }^{43}$ Escritura 1337, August 20, 1898, Notaria 3, Archivo General de la Nación (Colombia). No name for the company was specified at that time.

${ }^{44}$ The name appeared in documents and reports of the Ministerio de Hacienda and the German Resident in Bogotá.
} 
TABLE 1. Companies related to the Chivor 1 and 2 emerald mines in Colombia.

\begin{tabular}{|c|c|c|c|}
\hline Company Name & $\begin{array}{l}\text { Formation Date } \\
\text { Registration Date }\end{array}$ & $\begin{array}{l}\text { Incorporators and Agents in } \\
\text { Colombia }\end{array}$ & References \\
\hline $\begin{array}{l}\text { Compañía de las Minas de } \\
\text { Esmeraldas de Chivor; } \\
\text { Sociedad Ordinaria de las Minas } \\
\text { de Chivor }^{\mathrm{a}}\end{array}$ & $\begin{array}{l}\text { August 20, } 1898 \\
\text { (Formation in Colombia) }\end{array}$ & $\begin{array}{l}\text { Francisco Restrepo, Enrique González, } \\
\text { Bernardo Escovar, Nuñez \& Cía. }\end{array}$ & $\begin{array}{l}\text { Escritura 1337, August 20, 1898, } \\
\text { Notaria } 3\end{array}$ \\
\hline Syndikat El Chivor & $\begin{array}{l}\text { February 14, } 1914 \\
\text { (Formation in Germany) }\end{array}$ & $\begin{array}{l}\text { August Stauch, Hjalmar Schacht, } \\
\text { Rudolf Hahn \& Sons, Fritz Klein }\end{array}$ & $\begin{array}{l}\text { Historical Archive of the German } \\
\text { Ministry of Foreign Affairs }\end{array}$ \\
\hline \multirow{2}{*}{$\begin{array}{l}\text { Colombian Emerald Syndicate, } \\
\text { Ltd. }\end{array}$} & $\begin{array}{l}\text { June 22, } 1918 \\
\text { (Formation in U.S.) }\end{array}$ & $\begin{array}{l}\text { S.J. Nathan, Edgar W. Ward, J.E. } \\
\text { Cochrane, M.F. O'Dell, F. A. Daly }\end{array}$ & $\begin{array}{l}\text { State of Delaware, Department of } \\
\text { State, Division of Corporations }\end{array}$ \\
\hline & $\begin{array}{l}\text { May 7, } 1920 \\
\text { (Registration in Colombia) }\end{array}$ & Agent: Miguel S. Uribe Holguin & $\begin{array}{l}\text { Escritura 1402, May 7, 1920, } \\
\text { Notaria } 1\end{array}$ \\
\hline \multirow{3}{*}{$\begin{array}{l}\text { Colombian Chivor Emerald } \\
\text { Company } \\
\text { Compañía Colombiana de } \\
\text { Esmeraldas de Chivor } \\
\text { (Operating company of the } \\
\text { Colombian Emerald Syndicate) }\end{array}$} & & Wilson E. Griffiths, Carl K. MacFadden & \multirow{3}{*}{$\begin{array}{l}\text { Escritura 2041, July 6, 1920, } \\
\text { Notaria } 1\end{array}$} \\
\hline & & $\begin{array}{l}\text { Directors: Carl K. MacFadden, } \\
\text { Nathaniel W. Ross, William M. Schaill }\end{array}$ & \\
\hline & & Agent: Miguel S. Uribe Holguin & \\
\hline \multirow{2}{*}{ Chivor Emerald Corporation } & $\begin{array}{l}\text { March 6, } 1924 \\
\text { (Formation in U.S.) }\end{array}$ & $\begin{array}{l}\text { Samuel C. Wood, Harry C. Hand, } \\
\text { Raymond J. Gorman }\end{array}$ & $\begin{array}{l}\text { State of Delaware, Department of } \\
\text { State, Division of Corporations }\end{array}$ \\
\hline & $\begin{array}{l}\text { February 16, } 1925 \\
\text { (Registration in Colombia) }\end{array}$ & Agent: Miguel S. Uribe Holguin & $\begin{array}{l}\text { Escritura 344, February 16, 1925, } \\
\text { Notaria } 1\end{array}$ \\
\hline \multirow{2}{*}{$\begin{array}{l}\text { Colombia Emerald Development } \\
\text { Corporation } \\
\text { (Operating company in U.S. and } \\
\text { Colombia, connected to the } \\
\text { Chivor Emerald Corporation) }\end{array}$} & $\begin{array}{l}\text { November } 7,1924 \\
\text { (Formation in U.S.) }\end{array}$ & \multirow{2}{*}{$\begin{array}{l}\text { Edmund J. MacNamara, Ernest W. } \\
\text { Brown, William B. Anderson } \\
\text { Agent: Miguel S. Uribe Holguin }\end{array}$} & $\begin{array}{l}\text { State of Delaware, Department of } \\
\text { State, Division of Corporations }\end{array}$ \\
\hline & $\begin{array}{l}\text { July } 11,1925 \\
\text { (Registration in Colombia) }\end{array}$ & & $\begin{array}{l}\text { Escritura } 1607, \text { July } 11,1925 \text {, } \\
\text { Notaria } 1\end{array}$ \\
\hline \multirow{2}{*}{$\begin{array}{l}\text { Chivor Emerald Mines, Inc. } \\
\text { (Change of name from the } \\
\text { Colombia Emerald Development } \\
\text { Corporation) }\end{array}$} & $\begin{array}{l}\text { September 28, } 1933 \\
\text { (Change of name in U.S.) }\end{array}$ & \multirow{2}{*}{$\begin{array}{l}\text { Agents (1920-1970): } \\
\text { Miguel S. Uribe Holguin } \\
\text { Hernando Uribe Cualla } \\
\text { Eduardo Torres R. }\end{array}$} & $\begin{array}{l}\text { State of Delaware, Department o } \\
\text { State, Division of Corporations }\end{array}$ \\
\hline & $\begin{array}{l}\text { November 17, } 1934 \\
\text { (Change of name } \\
\text { registered in Colombia) }\end{array}$ & & $\begin{array}{l}\text { Escritura 2045, November 17, } \\
\text { 1934, Notaria } 1\end{array}$ \\
\hline
\end{tabular}

the process. Emerald samples were sent to Europe to attract investors (e.g., major European banks), and an estimated price of $£ 40,000$ was suggested in early negotiations. ${ }^{45}$ However, no deal culminated before outbreak of the Colombian civil war (October 1899-November 1902) stopped all activities at the mine. Meanwhile, controversy had also developed over the water supply, as the irrigation canal ran across private land owned by the local Acosta family, and available water was also used for a nearby hacienda. ${ }^{46}$

In the following era, activities pertaining to Chivor tended to be more financial than operational in nature. Tax payments, share transfers, and investment pursuits featured heavily, while mining was relatively minimal. Annual taxes for Chivor 1 and 2 were paid by González in 1898, 1899, and 1900 at the rate of 5 pesos per mine per year. Taxes for the mines were then paid for 20 years in advance, at the rate of 100 pesos per mine, by Antonio Núñez of Núñez \& Compañía on behalf of the shareholders. ${ }^{47}$

${ }^{45}$ Letter from Núñez \& Compañía, December 16, 1898, to Restrepo. Lorenzo Merino, who had recently completed a ten-year lease of the Muzo emerald mines (1886-1896), was involved in the discussions.

${ }^{46}$ Letters by Núñez \& Compañía, June 18 and June 23, 1898, to Restrepo.

${ }^{47}$ Escritura 1242, December 3, 1901, Notaria 3, Archivo General de la Nación (Colombia). See also Reports by the German Resident in Bogotá, Dorotheus Kracker von Schwartzenfeldt, November 16 , 1912, and by a member of the German Residency in Bogotá, Wilhelm Gerlach, November 15, 1912, German Federal Archive; Diario Oficial (Colombia), 48, No. 14720 (1912), pp. 812-813; Report by Dr. Antonio José Cadavid, March 18, 1913, Historical Archive of the German Ministry of Foreign Affairs; Domínguez, 1965. 


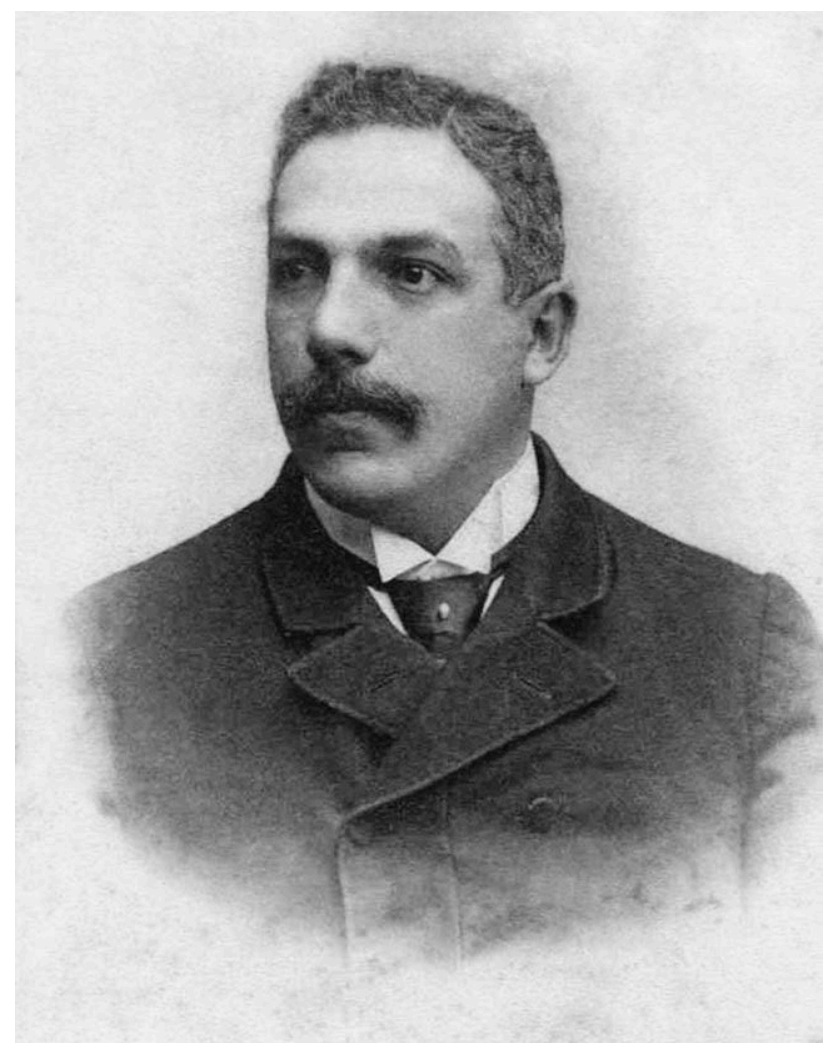

Figure 6. Dr. Emiliano Isaza Gutiérrez-lawyer, scientist, politician, diplomat, and minister-was one of the most prominent shareholders in the Compañía de las Minas de Esmeraldas de Chivor. He cooperated with Klein in the 1910s but as president sold the company in 1919 to American interests. Courtesy of Banrepcultural, Bogotá.

in Chivor's history likewise became involved as shareholders during this period, such as the English businessman and miner Christopher Ernest Dixon (1868-1961; see box A), who purchased three shares between 1900 and 1902,,52 and Dr. Emiliano Isaza Gutiérrez (figure 6), ${ }^{53}$ who acquired three shares in $1905^{54}$ and would later become president of the Compañía de las Minas de Esmeraldas de Chivor. Prices for one share in paper currency increased from 2,000 pesos in 1900 to 64,000 pesos in 1908 , but the inflation factor impacting paper currency changed markedly during the Colombian civil war (again, see table 2). ${ }^{55}$ The values of different Colombian and foreign currencies are compared in table 3.

Throughout the same period, the mine owners continued seeking foreign investment or participation. In November 1901, Dixon was authorized for a term of six months to attempt to form a company in Europe that would be responsible for organizing and operating the emerald mines. ${ }^{56} \mathrm{~A}$ different tack was
TABLE 3. Currency equivalencies circa 1910-1914. ${ }^{\text {a }}$

\begin{tabular}{lcccc}
\hline & £ Sterling & Peso Oro & \$US Gold & Mark \\
\hline £ Sterling & 1 & 5 & 5 & 20 \\
Peso Oro & 0.2 & 1 & 1 & 4 \\
\$US Gold & 0.2 & 1 & 1 & 4 \\
Mark & 0.05 & 0.25 & 0.25 & 1 \\
\hline${ }^{a}$ As used in various publications and contracts of the period.
\end{tabular}

then taken in March 1904, when Alvaro Uribe was authorized for a nine-month term to search for a foreign entity, especially in France and England, to lease Chivor for an estimated price of $£ 10,000 .^{57}$ As to the apparent lack of success of such efforts, the United States Consul-General in Bogotá, Snyder, wrote in 1904: "The prohibitively high price asked by the owners of these five mines, called the 'Chivor group' is the reason, I am informed, that they are not being worked." ${ }^{\prime 58}$

Meanwhile, a few months before the end of the civil war, Restrepo had left Colombia. He arrived in Quito, Ecuador, in June 1902, accompanied by his older son Anibal and two other Colombians. In Ecuador, Restrepo worked on government projects such as road and railway construction, and he was involved in gold mining in the Oriente region as owner and/or supervisor of several gold mines. ${ }^{59}$ In early 1904, Restrepo was asked to return to his home country because there was urgent need of an experi-

${ }^{52}$ Escritura 915, December 7, 1900, Notaria 3, Escritura 1201, November 21, 1901, Notaria 3, and Escritura 108, March 9, 1902, Notaria 3, Archivo General de la Nación (Colombia).

${ }^{53}$ Dr. Emiliano Isaza Gutiérrez (1850-1930) studied law and political science, becoming a professor at the University of Antioquia in 1875 In 1876 he moved to Bogotá. Throughout his career, he authored a number of academic publications, including a classic Spanish grammar textbook Gramática Práctica de la Lengua Castellana (1880), and he served Colombia in various diplomatic capacities, such as plenipotentiary minister in Ecuador and as minister of public instruction in the homeland (1908-1909). See Martínez, 1950.

${ }^{54}$ Escritura 758, October 28, 1905, Notaria 3, Archivo General de la Nación (Colombia).

${ }^{55}$ For comparison, monthly salaries at the Muzo emerald mine in 1904 were 30,000 pesos paper (300 pesos oro) for the director and $3,000-4,000$ pesos paper (30-40 pesos oro) for the foreman or other staff. Junta Nacional de Amortización, Informe al Congreso y al Gobierno Ejecutivo 1904, p. 62.

${ }^{56}$ Escritura 1172, November 12, 1901, Notaria 3, Archivo General de la Nación (Colombia).

${ }^{57}$ Escritura 172, March 5, 1904, Notaria 3, and Escritura 193, March 16, 1905, Notaria 3, Archivo General de la Nación (Colombia).

${ }^{58}$ Bulletin of the International Bureau of the American Republics, Vol. 18 (1904), pp. 858-859.

${ }^{59}$ Restrepo's activities in Ecuador between 1902 and 1904 are well documented in newspaper articles, contracts, reports, and letters remaining in the possession of his family. 


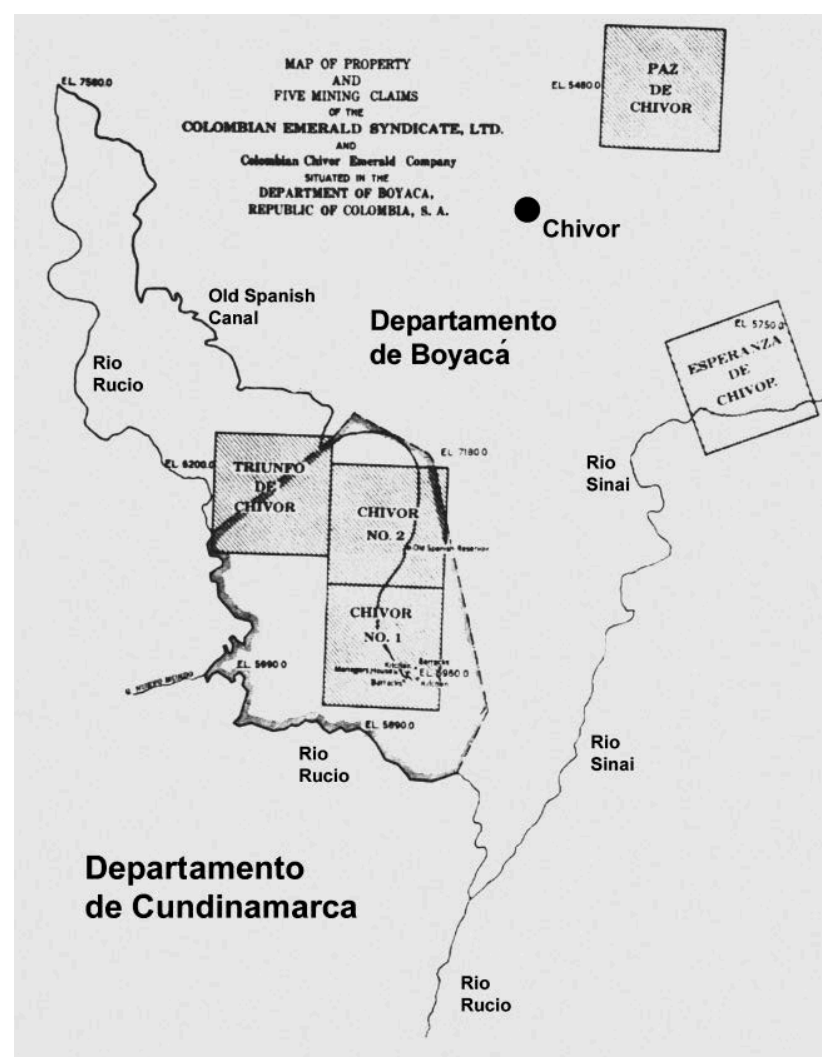

Figure 7. Map published in 1921 showing the location of the Chivor 1 and 2 emerald mines between the valleys of the Río Rucio and the Río Sinai in the Departamento de Boyacá, near the boundary with the Departamento de Cundinamarca. The mining titles for Chivor 1 and 2, measuring one square kilometer each, were registered in 1889 to Francisco Restrepo and partners; three additional mining titles were registered in 1904 for the Triunfo de Chivor, Paz de Chivor, and Esperanza de Chivor claims. After Canova (1921), representing the mine boundaries as assumed by the Colombian Emerald Syndicate, Ltd.; the town of Chivor was added. Note: In a map prepared by the Ministerio de Minas y Petróleos in 1941, Paz de Chivor and Esperanza de Chivor are located much closer to Chivor 1 and 2, at a distance of approximately $1 \mathrm{~km}$.

enced miner to direct the Muzo emerald mines. Restrepo began in that position in March $1904 .^{60}$

The year 1904 also saw a widening of the focus for investment activities pertaining to Chivor, beyond the existing two claims. On August 25, 1904, Restrepo, González, Escovar, Carlos Uribe, and Núñez \& Compañía purchased land in the Chivor area, between Río Rucio and Río Sinai, from Aurelio Ruedo Acosta. ${ }^{61}$ The purchase price was 100,000 pesos, and 20,000 pesos were paid by each of the five principal shareholders. Thereafter the Compañía de

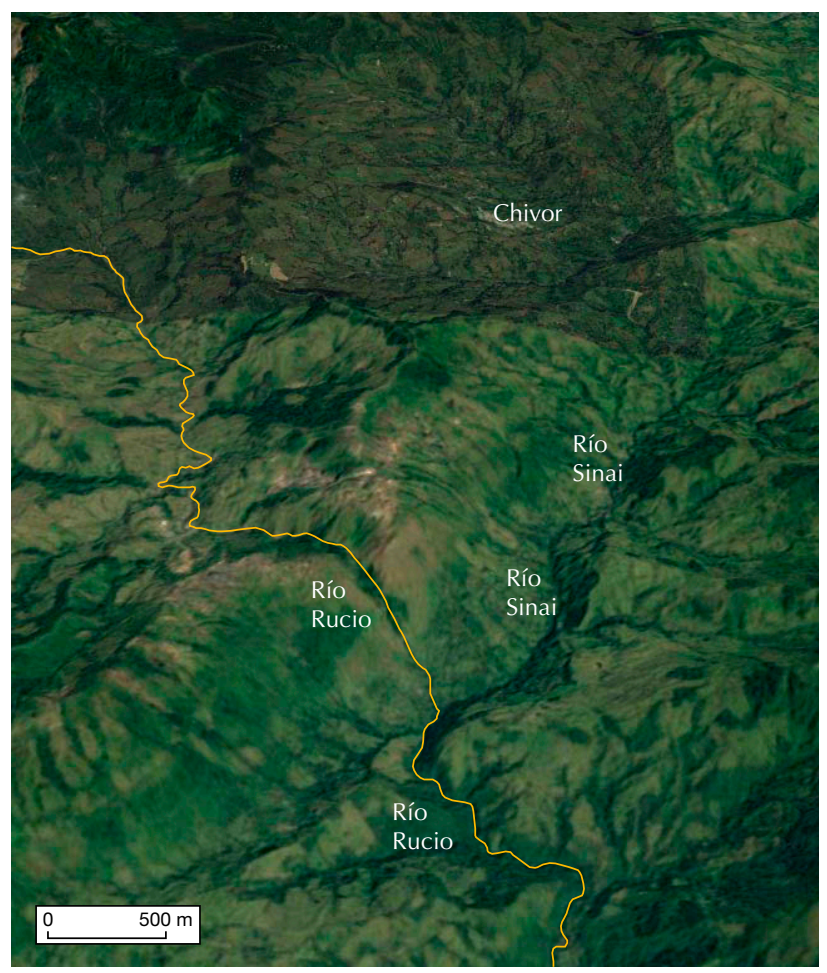

Figure 8. Satellite photo of the region between the valleys of the Río Rucio and the Río Sinai where the areas covered by the mining titles for Chivor 1 , Chivor 2, and Triunfo de Chivor are located. The area is situated in the Departamento de Boyacá, near the boundary with the Departamento de Cundinamarca (yellow line), which runs partly along the Rio Rucio valley. Modified from Google Earth; the town of Chivor and the labeling were added.

las Minas de Esmeraldas de Chivor was treated as the owner of the Chivor 1 and 2 mining titles and of land in the area. Through this purchase, the mine owners resolved with the Acosta family the controversy over the water supply that had plagued the site since the late 1890 s.

On December 13, 1904, three additional mining titles were registered in the vicinity of Chivor 1 and 2: "Triunfo de Chivor," "Paz de Chivor," and "Esperanza de Chivor" (figures 7 and 8), with Restrepo, Henrique Campo, and Dixon named as the co-owners. ${ }^{62}$ From that time, the five mining titles in the

${ }^{60}$ El Ecuador. Guía Comercial, Agrícola, e Industrial de la República (1909), Guayaquil, Compañía "Guía del Ecuador," pp. 243-251; Ochoa Ortiz, 1921.

${ }^{61}$ Escritura 1479, August 25, 1904, Notaria 2, and Escritura 3084, December 27, 1919, Notaria 1, Archivo General de la Nación (Colombia).

${ }^{62}$ Diario Oficial (Colombia), 48, No. 14720 (1912), pp. 812-813. 


\section{Box A: Christopher Dixon's Legacy in Colombian Emerald Mining}

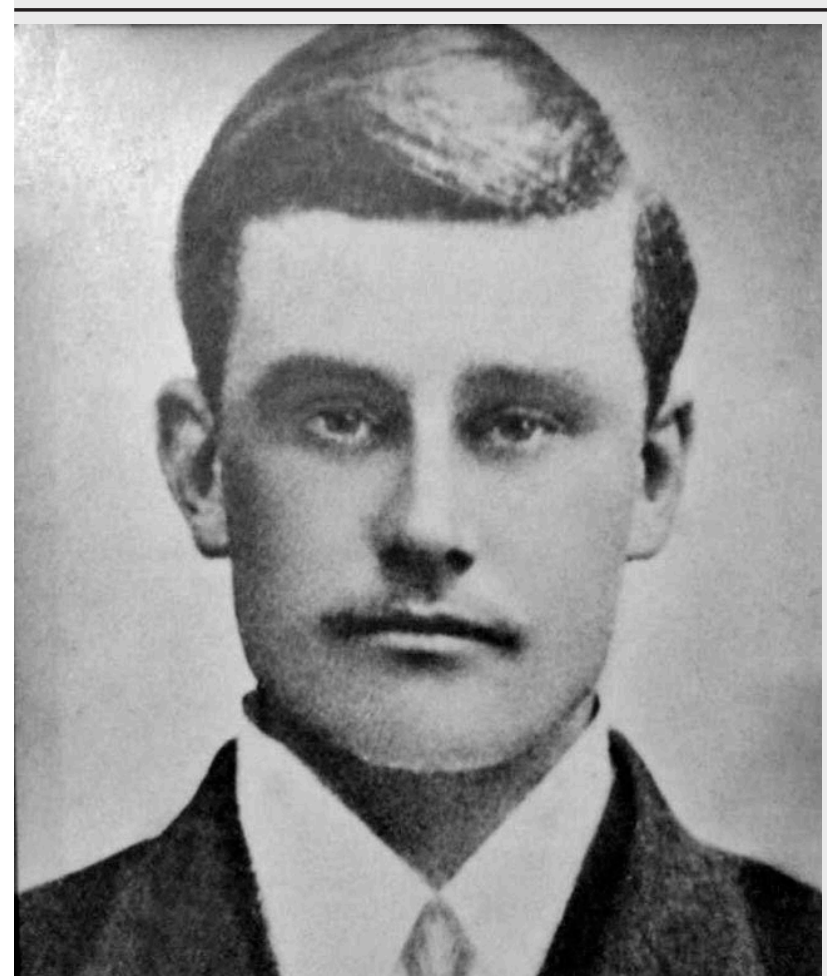

Figure A-1. Christopher Dixon worked on behalf of the English Mining Syndicate, Limited, when the company operated the Muzo mine during the 1890s and early 1900s. Dixon later became one of the shareholders in the Compañia de las Minas de Esmeraldas de Chivor that owned the mining titles for Chivor 1 and 2. After the mine was sold in 1919 to the U.S.-based Colombian Emerald Syndicate, Ltd., he served as its official representative in Colombia in the early 1920s. Photo circa 1900, public domain.

Christopher Ernest Dixon was born in 1868 in Watlington, Oxfordshire, England, the eleventh of Dr. Henry and Helen Dixon's twelve children. In the mid to late 1880s, he traveled to South America along with his brother Frank (1865-1956) to join an elder brother George (1861-1911), who had been prospecting for gold and silver in the state of Tolima, in central Colombia, since $1884 .^{1}$

Although the activities and precise whereabouts of the two younger Dixon brothers during their early years in Colombia $^{2}$ remain obscure, by 1889 , at the age of 21 , Christopher (figure A-1) was already operating at least 24 gold and silver mines in the Mariquita area, in northern Tolima. ${ }^{3}$ During this period, George worked for British mining companies at the Silencio mine, in central Tolima and elsewhere. ${ }^{4}$ Over the course of the 1880 s, Tolima had become a mining bonanza for gold and silver seekers, attracting prospectors and investors from neighboring Antioquia, as well as many foreigners. During his seven-year stay in Colombia, George might also have been involved in emerald prospecting and mining at Muzo, as suggested by photos from the family album (figures A-2 and A-3). ${ }^{5}$

Although Christopher Dixon would become most known for his activities with emerald, he was always looking for new commercial opportunities and was active across a variety of sectors throughout his career. In 1891, he became associated with the "Magdalena Estates Company," a real estate development venture. ${ }^{6}$ In the 1892 to 1893 period, he and his brother Frank obtained grants to parcels of public land in northern Tolima and Caldas. ${ }^{7}$ In 1910, he was named administrator of the " $\mathrm{H}$. and U. Rubber and Coffee Estates, Limited." 8 Then, in 1916, Dixon turned to cattle breeding, already an important industry in Colombia, and planned to build a new meat-packing plant on the Caribbean coast. ${ }^{9}$

The earliest known reference to emeralds in Dixon's career is from 1896, when he became an agent of the English Mining Syndicate, Limited, a British company operating the Muzo mines, a position he held until October $1900 .{ }^{10}$ The early 1900 s then found Dixon buying shares in the Compañía de las Minas de Esmeraldas de Chivor (see the main text) and being involved in various other activities around Chivor.

Meanwhile, in August 1898, preliminary applications for three additional mining claims in the Chivor area had been filed by Francisco Restrepo and various partners. ${ }^{11}$ Such action was taken contemporaneously with when Restrepo was involved at Chivor in efforts to restore the water supply. The three mining claims later became known as El Triunfo de Chivor, La Paz de Chivor, and La Esperanza de Chivor.

${ }^{1}$ Transactions of the Institution of Mining and Metallurgy, Vol. 21 (1912), p. 723.

${ }^{2}$ The arrival of three members of the Dixon family in Colombia in 1886 is documented in the Diario Oficial (Colombia), 22, No. 6836 (1886), p. 1114, but further information as to identities is unavailable. ${ }^{3}$ Informe presentado al Congreso de la Republica en sus sesiones ordinarias de 1890 por el Ministro de Hacienda, Casa Editorial de J.J. Pérez, Bogotá, 1890.

${ }^{4}$ Skinner, 1889-1890, 1891-1892.

${ }^{5}$ Simon Hamilton (great-grandson of George Dixon), pers. comm., 2018

${ }^{6}$ The Mining Journal, Railway and Commercial Gazette, Vol. 61 (1891), p. 851.

${ }^{7}$ Informe del Ministro de Hacienda de la Republica de Colombia al Congreso Constitucional de 1894, p. 101; LeGrand, 1988.

${ }^{8}$ India-Rubber Journal, Vol. 43 (1912), p. 21.

${ }^{9}$ Memoria del Ministro de Agricultura y Comercio al Congreso de 1918, pp. 173-177.

${ }^{10}$ Atuesta, 1899; Escritura 314, October 31, 1900, Notaria 3, Archivo General de la Nación (Colombia); Gaceta Judicial (Colombia) 15 (1901) pp. 169-173 and 16 (1903) pp. 78-79; Céspedes Cubides, 2017.

${ }^{11}$ Diligencia No. 2, Municipality of Macanal, August 8, 1898; Aviso No. 81, Municipality of Ubalá, August 21, 1898; Aviso No. 82, August 21, 1898, Municipality of Ubalá. 


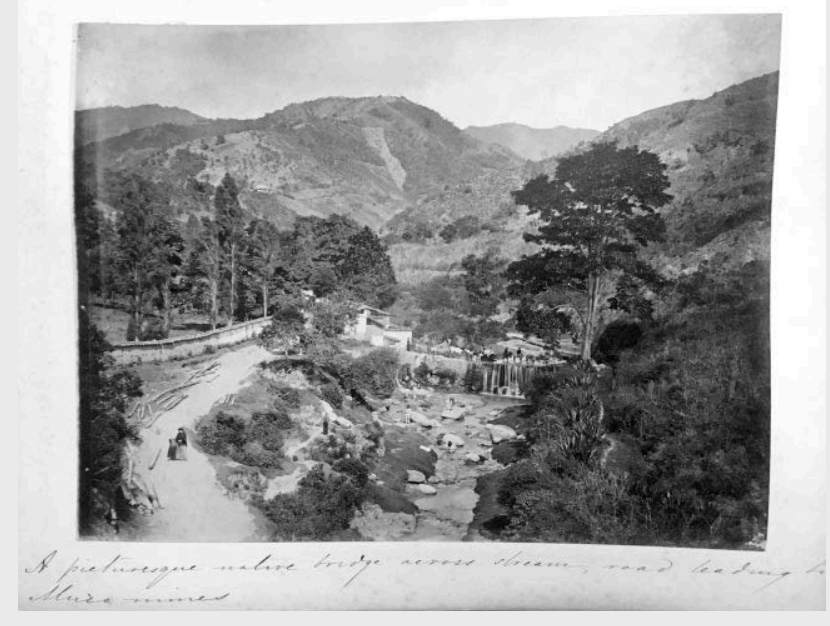

Figure A-2. View of the landscape of the Muzo area, from the family album of George Dixon, taken before 1890, with the handwritten comment reading: "A picturesque native bridge across stream. Road leading to Muzo mines." Courtesy of Simon Hamilton.

As shown in a map by Canova (1921), El Triunfo de Chivor adjoined directly to Chivor 1 and 2, situated between the valleys of the Río Rucio and the Río Sinai (see figure 7 of the main text). La Paz de Chivor and La Esperanza de Chivor were located northeast and southeast, respectively, of the current town of Chivor. No indication exists as to why these three particular locations were chosen for claims-it is possible that emerald samples and/or former native or Spanish workings (tunnels) had been discovered by prospecting or other activities in the areas and that the claims were defined so as to cover mining rights over those regions. Regardless, and for reasons otherwise not elucidated but perhaps impacted by the outbreak of the Colombian civil war (The Thousand Days' War, 1899-1902), the registration process was not completed, and no mining claims were officially granted.

After the war and Restrepo's return to Colombia from a sojourn in Ecuador (see main text), the registration process was restarted. A February 1904 agreement between Henrique Campo (a Swiss citizen), ${ }^{12}$ Dixon, and Restrepo set forth the conditions under which the they would join in new applications for the three claims, namely, that ownership would be divided equally among the three partners (figure A-4). The applications were then filed in September 1904, ${ }^{13}$ and the three mining titles were granted on December 13 of that year, ${ }^{14}$ with annual taxes being paid in advance for the period through $1910 .{ }^{15}$ Approximately one week later, on December 19, 1904, the three owners formally granted Dixon a power of attorney covering all future matters related to the three claims. ${ }^{16}$

Consistent with what had generally transpired to that point with respect to Chivor 1 and 2, focus for the newly acquired claims centered on investment pursuits rather than practical mining. The 1905 to 1906 and 1915 to 1916

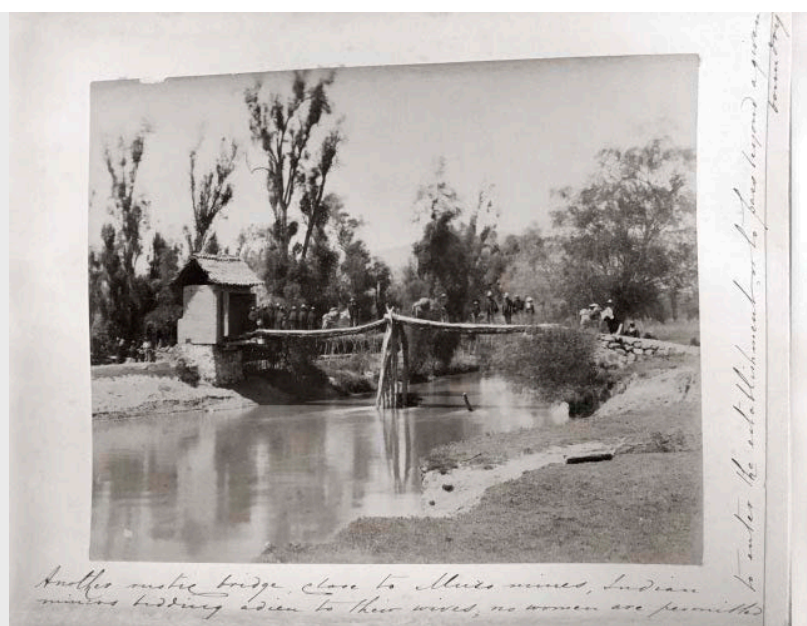

Figure A-3. A bridge in the Muzo area, from the family album of George Dixon, taken before 1890, with the handwritten comment reading: "Another rustic bridge, close to Muzo mines. Indian miners bidding adieu to their wives, no women are permitted to enter the establishment or to pass beyond a given boundary." Courtesy of Simon Hamilton.

periods in particular saw flurries of activity in this regard, with Dixon engaged in extensive correspondence and even travel to England ${ }^{17}$ in the search for investors. Paralleling these efforts was Dixon's long-running battle against the change in Colombian mining laws that had taken effect in 1905 (Law No. 40 of 1905), restricting applications for new emerald mines and increasing the tax burden on existing mines. A complaint was lodged against the Colombian government, and Dixon, supported by British officials in Bogotá, embarked on a multiyear quest to establish that he had been harmed by the change and was entitled to recompense from Colombia. ${ }^{18}$

Dixon's allegations centered on concerns that the higher taxes would prevent profitable mining and should not be applied to titles granted before 1905 and that the uncertain and detrimental situation for mine owners had

${ }^{12} \mathrm{Also}$ referred to as Enrique Campo in several documents, with his signature on notarial acts generally taking the form of Henrique Campo (used hereinafter).

${ }^{13}$ Letter from Christopher Dixon, December 3, 1904, to Restrepo. ${ }^{14}$ Diario Oficial (Colombia), 48, No. 14720 (1912), pp. 812-813.

${ }^{15}$ Foreign Office, Political Departments, General Correspondence from 1906 to 1966, Colombia: Code 11, Files 47 - 6847 and 904, The National Archives, Kew, London.

${ }^{16}$ Escritura 2326, December 19, 1904, Notaria 5, Archivo General de la Nación (Colombia).

${ }^{17}$ File Christopher Dixon, Names and Descriptions of British Passengers Embarked at the Port of Tilbury, January 13, 1915,

MyHeritage.com.

${ }^{18}$ Foreign Office, Political Departments, General Correspondence from 1906-1966, Colombia: Code 11, Files 47 - 6847 and 904, The National Archives, Kew, London. 


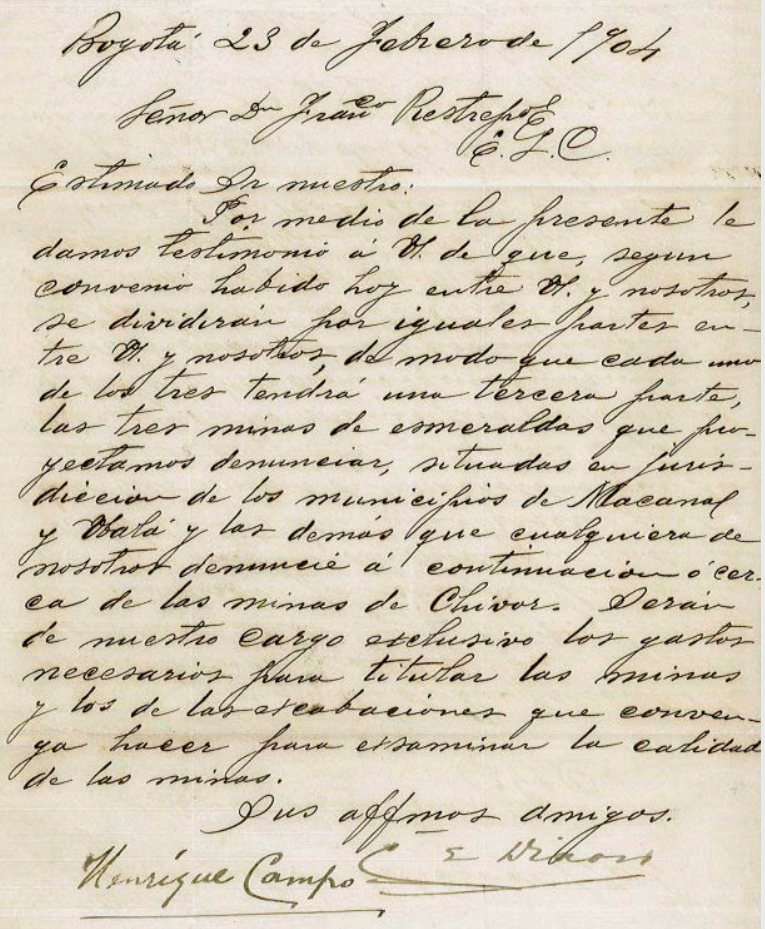

Figure A-4. A letter dated February 23, 1904, from Henrique Campo and Christopher Dixon to Restrepo memorialized an agreement under which the three would join in applying for the three additional claims in the Chivor area, sharing ownership equally and with all expenses paid by Dixon and Campo. Courtesy of Eduardo Restrepo Ortega.

caused potentially interested investors to turn away. ${ }^{19}$ His assertions also apparently became increasingly exaggerated as the contest went on, with documents prepared by British officials even giving Dixon credit for having discovered the three mines. ${ }^{20}$ In negotiations he offered to settle by selling the mines to the Colombian government for $£ 200,000$ but was asked to prove the value of the claims through an international expert. ${ }^{21} \mathrm{He}$ failed to do so and instead continued paying annual taxes for the three mines up through 1922. ${ }^{22}$

By 1920, Dixon had been named as the Colombian manager for the Colombian Emerald Syndicate, Ltd., the American company that had just taken over the Chivor 1 and Chivor 2 mines (see main text). From this date onwards, the historical record about the three other claims of the so-called Chivor group is incomplete regarding specifics of any pertinent ownership transfers, and the few references are disjointed, if not contradictory, although all five mines eventually came to be considered in part or in full under the purview of the American company. ${ }^{23}$

Following his involvement with the Colombian Emerald Syndicate, Ltd., Dixon left the mine for a period but returned in the early 1930s to help Peter W. Rainier, then the administrator at the mine, fight attacking bandits. ${ }^{24}$ Later, he also cooperated with Rainier during field work at the Coscuez emerald deposit. ${ }^{25}$

Dixon remained in Colombia with his wife and children. His last known assignment was in the mid-1940s, as one of the participants in geological investigations carried out in Colombia by the Foreign Economic Administration, in cooperation with the United States Geological Survey. ${ }^{26}$ In the last years of his life, Dixon was celebrated in the U.S. as an authority on emerald mining. ${ }^{27}$ He died in Bogotá in 1961, and some of his descendants still live in Colombia. He will be remembered for the legacy he left in the history of Chivor and in the modern history of Colombian mining at large.

${ }^{19}$ lbid.

${ }^{20} \mathrm{lbid}$.

${ }^{21}$ File "Minas de Esmeraldas," Ministerio de Relaciones Exteriores, Archivo General de la Nación (Colombia).

${ }^{22}$ Diario Oficial (Colombia), 50, No. 15279 (1914), p. 396; Diario Oficial (Colombia), 51, No. 15557 (1915), p. 448; Diario Oficial (Colombia), 54, No. 16306 (1918), p. 121; Diario Oficial (Colombia), 58, No. 18425-18426 (1922), p. 243.

${ }^{23}$ For example, a 1920 listing of Restrepo's assets at the time of his death in 1914 included a one-third share in each of the three newer mines. Escritura 188, January 27, 1920, Notaria 3, Archivo General de la Nación (Colombia). In 1921, it was represented that the titles to all five mines of the Chivor group were under the ownership or control of the Colombian Emerald Syndicate, Ltd., or its operating entity the Colombia Chivor Emerald Company. Canova, 1921. Concomitant with the bankruptcy of the Colombian Emerald Syndicate in 1923, its assets were stated to incorporate complete ownership of Chivor 1 and 2 and one-third of the three newer claims. Jewelers' Circular, Vol. 87, No. 22 (1923), p. 91. Annual payments of taxes for the three claims were made from 1929 to 1931 by Pedro Ignacio Uribe, a Colombian entrepreneur and public figure (as well as founder of the "Compañía Colombiana del Petróleo" in 1918 along with Wilson E. Griffiths and Carl K. MacFadden). Diario Oficial (Colombia), 54, No. 16364 (1918), p. 56; Diario Oficial (Colombia), 65, No. 21072 (1929), p. 191; Diario Oficial (Colombia), 65, No. 21275 (1929), p. 780; Diario Oficial (Colombia), 67, No. 21674 (1931), p. 189.

${ }^{24}$ See main text, Part II, and Rainier, 1942.

${ }^{25}$ Rainier, 1933.

${ }^{26}$ Singewald, 1950.

${ }^{27}$ Lancaster Eagle-Gazette, July 2, 1951, p. 14. 


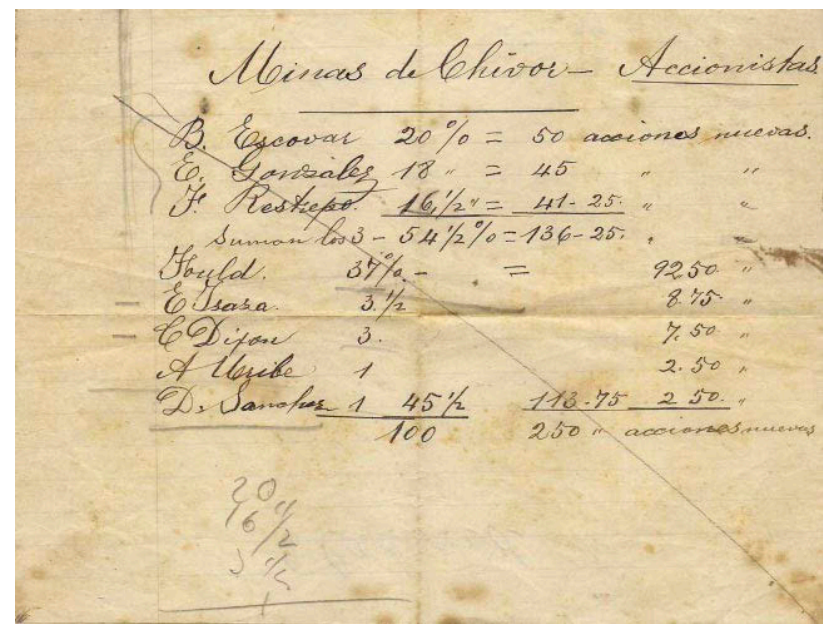

Figure 9. Handwritten register reflecting the ownership distribution of shares in the Chivor 1 and 2 emerald mines before and after a stock split between 1909 and 1912 that increased the capital from 100 to 250 shares. The participants and their holdings remained unchanged until the mines were sold in December 1919 to an American group. Courtesy of Eduardo Restrepo Ortega.

Chivor area were occasionally referred to collectively as the Chivor group (see also box B) ${ }_{1}^{63}$ but ownership of the three mining claims registered in 1904 and that of Chivor 1 and 2 remained, at least before 1920, formally separate (see also box A).

Yet, in stark contrast to the ongoing financial and investment maneuvers, practical mining activities were nearly nonexistent. As noted above, prior to the onset of the civil war, initial steps to clean old infrastructure and restore the water supply were undertaken ${ }^{64}$ but endeavors were curtailed by the conflict. The decade after the war then saw Restrepo, one of the key participants with practical mining experience, either out of the country (in Ecuador) or occupied with other ventures (Muzo). With Restrepo thus unavailable and the majority of the other shareholders focused on selling the mine, there was little incentive to invest further in operations.

By 1909, the shares were distributed among Fould \& Compagnie, six Colombians (mostly lawyers or engineers), and Dixon. ${ }^{65}$ Then, between March 1909 and October 1912, a stock split increased the capital from 100 to 250 shares (figure 9). ${ }^{66}$ By the time of the 1919 sale discussed below, ownership was distributed as follows: $92 \frac{1}{2}$ shares for Fould \& Compagnie, 50 for descendants of Escovar, 45 for González, 4111/4 for the widow and descendants of Restrepo, $83 / 4$ for Isaza, $7 \frac{1}{2}$ for Dixon, $2 \frac{1}{2}$ for Álvaro Uribe, and $2 \frac{1}{2}$ for Diódoro Sánchez (figure 9). ${ }^{67}$

\section{ACTIVITIES AT MUZO}

As alluded to previously, the year 1904 also witnessed relevant activity connected to the Muzo mines and to the broader Colombian emerald story that included Chivor. The important mines at Muzo, as well as at Coscuez, had been owned by the Colombian government since 1886 . Nonetheless, the mines were often leased to private operators against predetermined charges, and those tenants might even sublease to another individual or company. There were also repeated cycles of inactive periods. ${ }^{68}$

After the civil war, an entity known as the Sindicato de Muzo (Syndicate of Muzo, used hereinafter) was founded and took over exploitation of the Muzo mines from 1904 to $1909 .{ }^{69}$ Restrepo was named as director, and his son Anibal joined the mine's payroll as well. ${ }^{70}$ Toward the end of that period, in December 1908, it was agreed between the government of Colombia, the Syndicate of Muzo, and the Londonbased Colombian Emerald Company that the right to mine at Muzo from March 1909 would pass to the Colombian Emerald Company. ${ }^{71}$ Restrepo remained in his position until resigning in December 1909, expressing in a letter to the Colombian president that he did not agree with the new company's policies. ${ }^{72}$ The offered justification was that such policies were contrary to the interests of the Colombian nation.

The contract with the Colombian Emerald Company was to last for more than 20 years, but it was terminated by the government after just 14 months, in May $1910 .{ }^{73}$ Mining operations were taken over by

${ }^{63}$ For other mines that have been erroneously associated with Chivor, see also box $B$.

${ }^{64} \mathrm{See}$ also Bulletin of the International Bureau of the American Republics, Vol. 28 (1909), pp. 1027-1039.

${ }^{65}$ Escritura 3084, December 27, 1919, Notaria 1, Archivo General de la Nación (Colombia).

${ }^{66}$ Diario Oficial (Colombia), 48, No. 14720 (1912), 812-813; Escritura 3084, December 27, 1919, Notaria 1, Archivo General de la Nación (Colombia).

${ }^{67}$ Escritura 3084, December 27, 1919, Notaria 1, Archivo General de la Nación (Colombia).

${ }^{68}$ Informe del Ministro de Hacienda al Congreso de 1922, pp. 24-29.

${ }^{69}$ Diario Oficial (Colombia), 49, No. 15043 (1913), p. 3221.

${ }^{70}$ Junta nacional de Amortización, Informe al Congreso y al Gobierno Ejecutivo 1904, p. 60; Revista del Ministerio de Obras Públicas, 4 (1909), p. 49; Domínguez, 1965.

${ }^{71}$ Bulletin of the International Union of the American Republics, Vol. 29 (1909), pp. 1120-1121; Montaña, 1915.

${ }^{72}$ Letter from Restrepo, December 22, 1909, to the Colombian president Ramon González Valencia.

${ }^{73}$ Report by a member of the German Residency in Bogotá, Wilhelm Gerlach, November 15, 1912, German Federal Archive. 


\section{Box B: Mining Companies Erroneously Associated with Chivor}

Two additional mining enterprises were associated with Chivor by Sinkankas (1981): Somondoco Emeralds, Limited, a successor entity to the Somondoco Company, Limited; and the Emerald Mining Company of Colombia. ${ }^{1}$ The first company Sinkankas assumed worked at Chivor following the rediscovery by Restrepo but before Restrepo and Klein began their joint mining efforts there. The second company he realized did not fit with available references concerning the rediscovery and subsequent work. Evidence indicates, however, that each was actually involved with properties unrelated to the historical Spanish mines.

\section{SOMONDOCO COMPANY, LIMITED, AND SOMONDOCO EMERALDS, LIMITED}

Somondoco Company, Limited, was registered in London under chairman H.S. Sankey on July 1, 1895, with the stated purpose of acquiring the Somondoco emerald mines in the Republic of Colombia. ${ }^{2}$ Somondoco Emeralds, Limited, was then registered, also in London and under chairman H.S. Sankey, on May 13, 1899, as a reconstruction of the Somondoco Company, Limited, and with property reported to comprise the Somondoco emerald mines in the Republic of Colombia. ${ }^{3}$

Industry publications track the company's progress through the end of the nineteenth century and the first few years of the twentieth century. As of 1899, the situation was not promising: "Up to the present it has achieved nothing of importance, and the valuable stones it has found are only to be counted by the half-dozen. It now finds itself in sore straits for money...."4 Some improvement was reported at the annual shareholders meet- ing in 1900. The corporate reconstruction had brought sufficient funds to pay off liabilities, but practical work had suffered due to the ongoing civil war (1899-1902). Although the superintendent Mr. Gage and the consulting engineer Mr. Russell had been working at the deposit, and some stones were ready to be sent overseas, export was impossible given the hostilities and political disruptions. ${ }^{5}$

The situation at the 1901 annual meeting was similar. Mr. Gage and Mr. Russell reported that they "had not been able to obtain sufficient emeralds to put a profitable consignment upon the market," but they still hoped to make the mine productive: "[W]e have passed through a period of disturbance in the veins, but that is a matter, it appears, we get full compensation for, because a disturbance of the veins is generally a precursor of good and valuable stones when the veins reunite." 6 Such expectations fell short, however, as a court order to wind up the company was issued on December 15, 1904 , on the ground that the company was unable to pay its creditors. $^{7}$

The foregoing publications tracking the company's progress never clearly indicated the location of the prop-

'Sinkankas, 1981, p. 411.

${ }^{2}$ Skinner, 1896, 1897.

${ }^{3}$ Skinner, 1900.

${ }^{4}$ The Mining Journal, Vol. 69 (1899), p. 936

${ }^{5}$ The Mining Journal, Vol. 70 (1900), p. 1482.

${ }^{6}$ The Mining Journal, Vol. 71, (1901), pp. 1400-1401.

${ }^{7}$ Register of defunct companies, 1990. The International Stock Exchange of the United Kingdom and the Republic of Ireland, 2nd ed., Macmillan Publishers, London, 552 pp. the Colombian government from June 1910, and the government then appointed Restrepo as director on its behalf from January to May $1911 .{ }^{74}$ In early January 1913, production at Muzo was discontinued for several years due to lack of profitability ${ }^{75}$ and only resumed in $1923 .{ }^{76}$ Meanwhile, the termination of the contract in 1910 had resulted in lengthy negotiations on claims for damages involving both the Colombian Emerald Company and the Syndicate of Muzo.

\section{FRITZ KLEIN AND HIS EARLY ACTIVITIES IN COLOMBIA (1905-1913)}

Klein's family hailed from Idar, Germany, and was engaged in the gem trade. His father August Klein (1852-1927) began mining and purchasing gem- stones, mostly red and green tourmaline and aquamarine, in Brazil in the last decade of the nineteenth century. August Senior was supported in Brazil by his sons Gustav (1876-1931), Fritz (1882-1953), and August Junior (1886-1971) from 1902, 1904, and 1906, respectively. ${ }^{77}$ Although the Klein brothers were successful in their endeavors as gem merchants in Brazil, competition from other Idar traders in purchasing rough gemstones in Minas Gerais increased.

\footnotetext{
${ }^{74}$ Diario Oficial (Colombia), 47, No. 12241 (1911), p. 404; Diario Oficial (Colombia), 49, No. 15043 (1913), p. 3221.

${ }^{75}$ Pogue, 1917.

${ }^{76}$ Diario Oficial (Colombia), 59, No. 19011-19014 (1923), p. 572; Diario Oficial (Colombia), 59, No. 18849-18850 (1923), pp. 658659.

${ }^{77} \mathrm{Falz}, 1939$.
} 
erty involved. Nonetheless, other materials offered further insight. A 1902 report by the British Vice-Consul S.S. Dixon gave the Somondoco district as the location of the mine worked by Somondoco Emeralds, Limited, but it distinguished those workings from the historical Chivor mines. After discussing both Somondoco Emeralds, Limited, and the Muzo deposits, S.S. Dixon continued: "I am informed that an emerald-producing formation of great importance has been discovered by the aid of old Spanish parchments in the Somondoco district, but as yet has not been worked by the discoverers. At present only the old Spanish tunnels and workings indicating that in past centuries great mining operations had been carried on there...." ${ }^{\prime \prime}$ This report is the oldest known published reference related to the rediscovery of Chivor.

With similar import, a map published in 1913 showed emerald mines in the valley of the Río Somondoco near the small municipalities of Somondoco and Guazeque [Guateque] ${ }^{9}$, and Pogue (1917) expressly differentiated the historical Chivor workings from those along the river: "Some confusion of terms has arisen. These deposits [Somondoco or Chivor] are near the valley of Chivor, and have been called the Chivor deposits. Under Spanish dominion they came to be known as the Somondoco deposits... and by this name they are generally called in the literature. They do not, however, occur on Río Somondoco, but other less important deposits are known on that stream." Hence, all evidence points to one of these less important deposits in the Somondoco valley being the locality mined without great success by the British "Somondoco" company.

\section{EMERALD MINES OF COLOMBIA, LIMITED, AND EMERALD MINING COMPANY OF COLOMBIA}

Emerald Mines of Colombia, Limited, was registered in London on September 28, $1888 . .^{10}$ The company purchased the Yacopi mines, located in the Western Colombian Emerald Belt, where the Muzo and Coscuez mines are also situated. The following decade, a company called the Emerald Mining Company of Colombia was mentioned in a report by George Frederick Kunz incorporated in a publication from the United States Geological Survey. ${ }^{11}$ Kunz noted that a property had been acquired by the company that was expected to produce emeralds "quite as fine as those from the famous Muzo mine." Based on this report, the Colombia Mining Company of Colombia was later potentially associated with Chivor by Sinkankas, as previously stated. The identity of the property had not been specified by Kunz, leading to speculation connecting the company with the likewise famous Chivor mines. However, research indicates that the Emerald Mining Company of Colombia referred to by Kunz was most likely Emerald Mines of Colombia, Limited, and therefore was engaged at Yacopi, not Chivor.

${ }^{8}$ Dixon, 1902. A nearly identical text was published anonymously in Monthly Bulletin of the International Bureau of the American Republics, 13 (1902), pp. 1349-1350.

${ }^{9} \mathrm{Gamba}, 1913$

${ }^{10}$ Skinner, 1889-1890, 1891-1892.

${ }^{11}$ Mineral Resources of the United States: Calendar Year 1893. United States Geological Survey, 1894, pp. 696-697.
The growing competition prompted Fritz to travel through various South American countries such as Argentina, Bolivia, and Peru, always searching for new gem materials, sources, and trade opportunities.

Fritz Klein's first trip to Colombia occurred in 1905 and nearly ended in disaster. Purchase and sale of gemstones at that time was strictly controlled through government-authorized channels, and Klein sought to buy and export rough emeralds from a private Colombian middleman in violation of applicable regulations. He was accused of this infraction by the Syndicate of Muzo and arrested in Honda, in the department of Tolima. The emeralds he had acquired were confiscated. Only through intervention of the German Resident ${ }^{78}$ in Bogotá was he later released and permitted to leave the country. ${ }^{79}$
Given these incidents, returning to Bogotá would have been advisable only under protection of the German Resident. ${ }^{80}$ Nonetheless, Klein continued to pursue his goal of establishing himself in the Colombian emerald trade. In December 1907, for instance,

${ }^{78}$ Prior to 1914 , the German empire designated ambassadors to only a small number of important nations, with such individuals serving in cities such as Paris, London, Rome, Madrid, Washington, and St. Petersburg. For other countries, including Colombia, the German Empire designated officials termed residents, who held rights for purposes of international law essentially equivalent to those of ambassadors.

${ }^{79}$ Report by the former translator of the German Resident, September 1925, Historical Archive of the German Ministry of Foreign Affairs.

${ }^{80}$ Letter from Fritz Klein, January 19, 1909, to his brother-in-law August Hahn in Idar, Germany. 


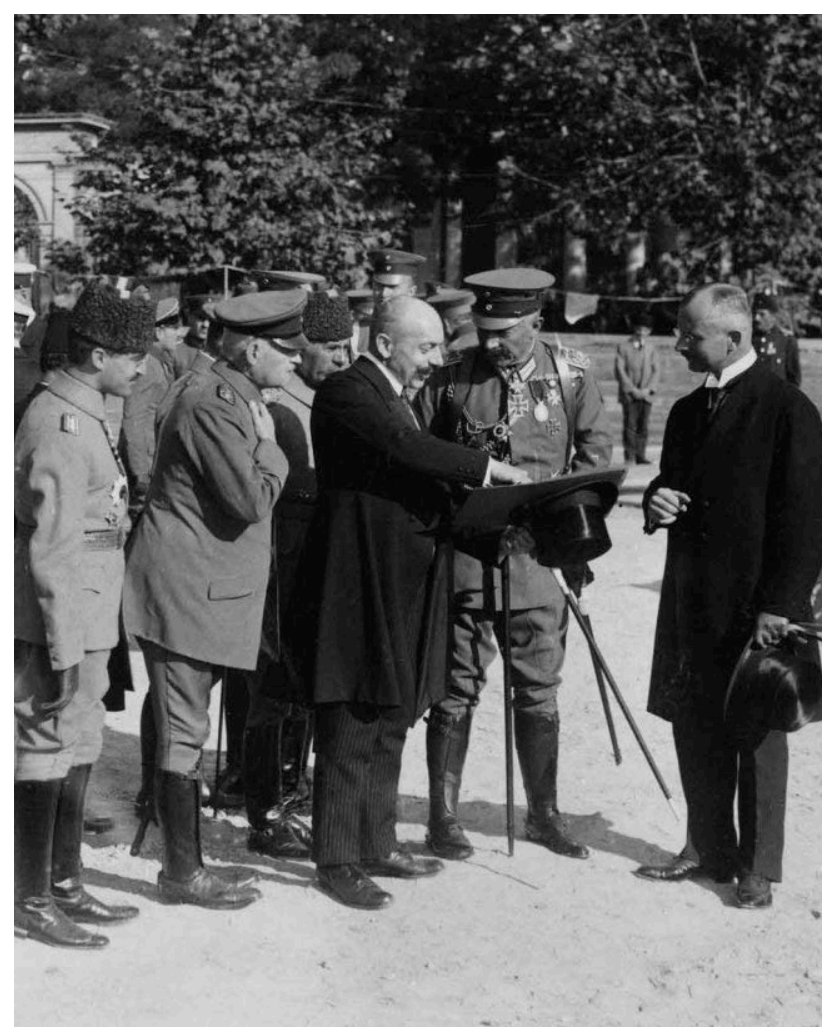

Figure 10. Dr. Ernst Jäckh, the brother-in-law of Fritz Klein, had access to the elite of the German Empire. In the 1910s, he served as an unofficial consultant with the Ministry of Foreign Affairs, Berlin, focusing on dealings with the Ottoman Empire (Turkey). Jäckh used his influence to further Klein's efforts both in Colombia and in finding investors for the Chivor project. Photo of Jäckh (center) in Istanbul in 1917 with German Emperor Wilhelm II (to the right of Jäckh); courtesy of the Ernst Jäckh collection, Columbia University.

Klein spent a short period in Barranquilla, a port city in northern Colombia, for a meeting with a local partner. ${ }^{81}$ By 1911, Klein's brother-in-law Dr. Ernst Jäckh $^{82}$ (1875-1959, figure 10) had asserted his influence at the Ministry of Foreign Affairs in Berlin to secure the protection needed for Klein to re-enter

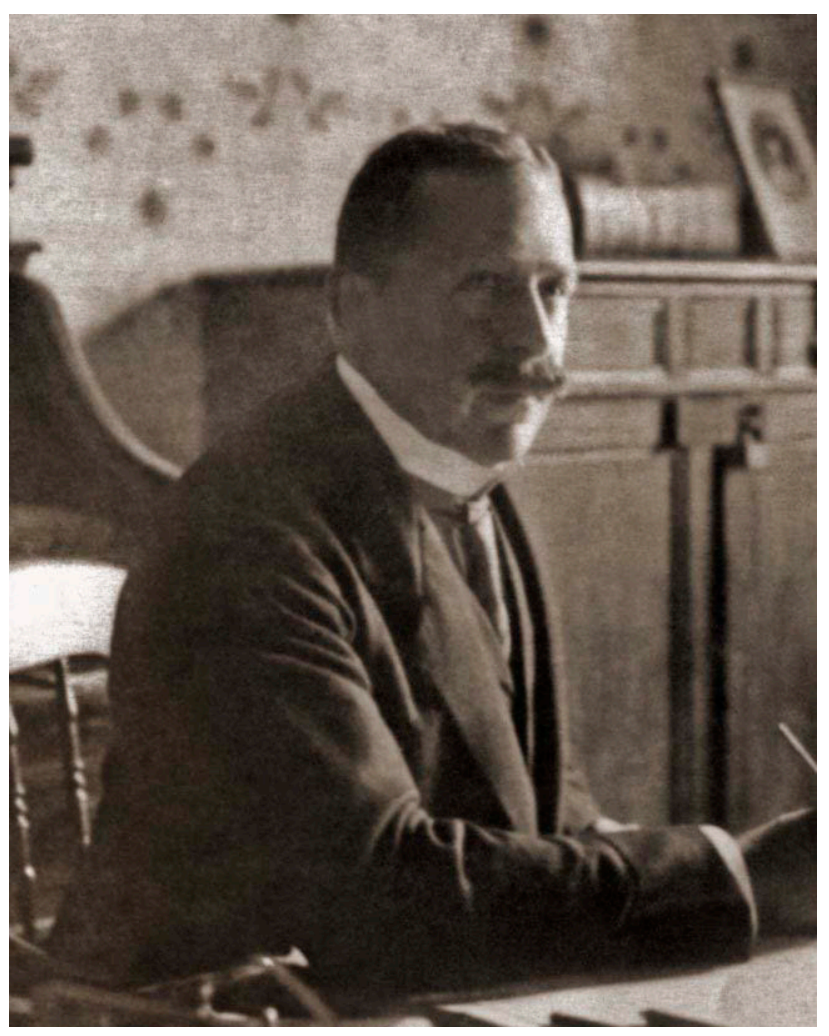

Figure 11. The German Resident in Bogotá,

Dorotheus Kracker von Schwartzenfeldt, was instructed by the German Ministry of Foreign Affairs to assist Fritz Klein in Colombia, especially as regarded purchasing the Chivor emerald mines. Kracker von Schwartzenfeldt later worked to clarify the legal situation in response to inquiries from the Syndicate El Chivor. Photo circa 1910, courtesy of the Historical Archive of the German Ministry of Foreign Affairs.

Colombia and stay in Bogotá. ${ }^{83}$ An order was issued to the German Resident in Bogotá, Dorotheus Kracker von Schwartzenfeldt (1869-1935, figure 11), in support of Klein's activities.

Klein returned to Bogotá in September $1911 .{ }^{84} \mathrm{He}$ initially negotiated with the Colombian government

\footnotetext{
${ }^{81}$ Letter from Fritz Klein, December 23, 1907, to his father August Klein in Idar, Germany.

${ }^{82}$ Dr. Ernst Jäckh married Fritz Klein's oldest sister, Bertha (1874-1928), in 1899. From 1902 to 1912 he was editor-in-chief of a daily newspaper in Heilbronn, Germany. Beginning in 1908, Jäckh also made numerous trips to Turkey, where he came into contact with high-ranking representatives of the Ottoman Empire and became a friend of the German diplomat Alfred von Kiderlen-Waechter, who was appointed Minister of Foreign Affairs in 1910. Jäckh moved to Berlin in 1912 and served as a "consultant" with the Ministry of Foreign Affairs. In 1920, Jäckh founded the German Academy for Political Sciences in Berlin, and during the 1920s, he was a member of the German delegation to several international conferences. Through a conversation with Hitler in

April 1933, he realized that he would not be able to keep his positions as the leader of various institutions. In May 1933 Jäckh emigrated together with his second wife Martha to Great Britain. He remained there until 1940, working for the British government in multiple functions. He moved in 1940 to the United States and taught as a professor at Columbia University in New York. See Jäckh, 1954.

${ }^{83}$ Letter from the German Minister of Foreign Affairs, Alfred von Kiderlen-Waechter, November 25, 1911, to Fritz Klein's brother-inlaw Dr. Ernst Jäckh.

${ }^{84}$ Fritz Klein traveled via New York, where he arrived in June 1911. File Fritz Klein, List or Manifest of Alien Passengers for the United States Immigration Officer at Port of Arrival, New York, June 1911, MyHeritage.com.
} 


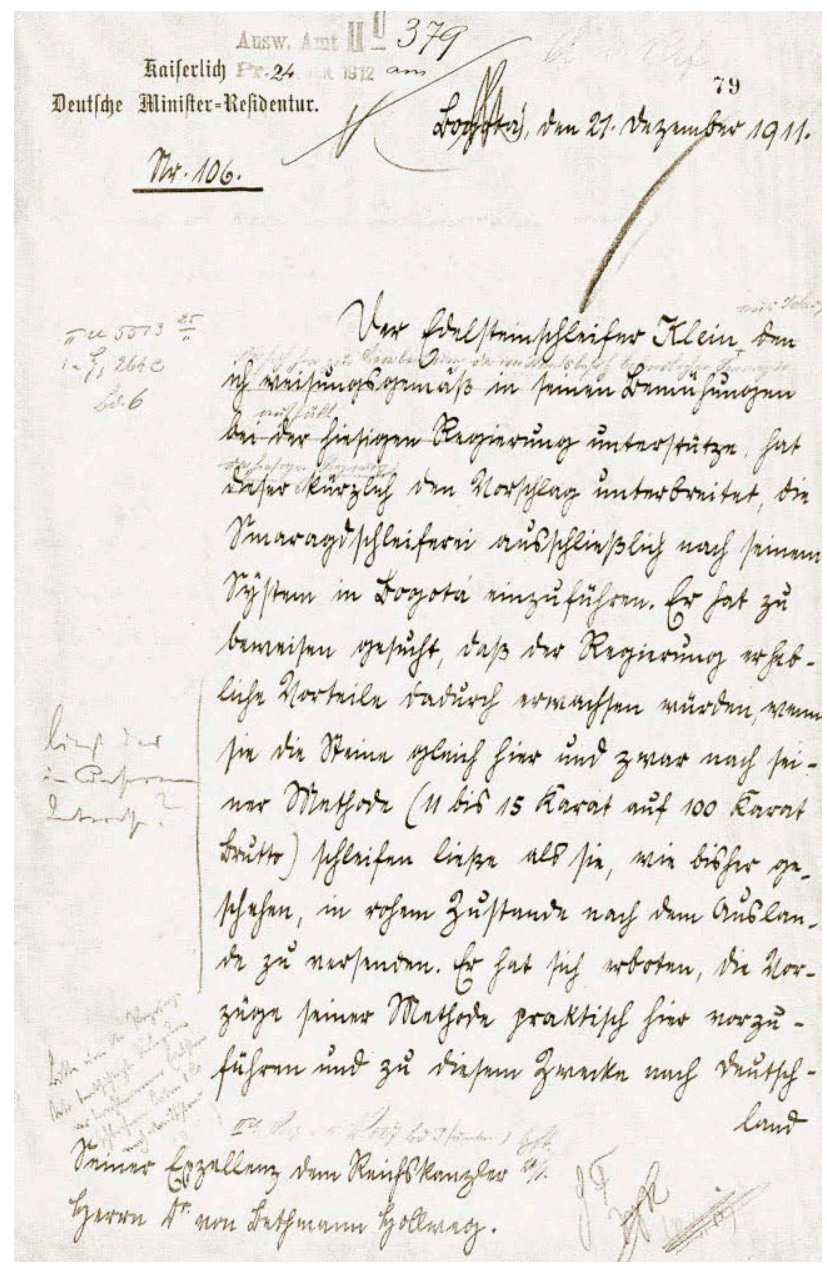

Figure 12. Opening page of a report from the German Resident in Bogotá, Dorotheus Kracker von Schwartzenfeldt, to the German Ministry of Foreign Affairs, dated December 21, 1911. The report described Fritz Klein's negotiations with the Colombian government in seeking permission to establish an emerald-cutting enterprise. Historical Archive of the German Ministry of Foreign Affairs.

in hopes of establishing an emerald-cutting enterprise (figure 12), but these efforts were unsuccessful. ${ }^{85}$

In November 1911, Klein became aware of the Chivor mine through another German, Hermann Span. ${ }^{86}$ A preliminary option contract for the mine, initiated by Span, was executed on February 13, 1912, and on June 5, 1912, after Klein conducted preliminary exploration of the mining area, terms were further formalized in a notarized option contract signed between Span and Klein on one hand and the mine owners Compañía de las Minas de Esmeraldas de Chivor on the other. The latter contract provided an exclusive right to purchase the mine for $£ 51,000$ (equivalent to 255,000 pesos oro; see again table 3 ) and was valid for a one-year term. ${ }^{87}$ Span and Klein were also given the right to mine samples in Chivor during the stated pendency of the option.

Klein was not alone in his interest in Chivor during this period. Dixon (see again box A), previously active in $\mathrm{Muzo}^{88}$ and already both a shareholder in the Compañía de las Minas de Esmeraldas de Chivor and a co-owner of the three newer Chivor mining titles, was engaged anew in exploration in the region, commencing additional mining ventures. As reported in 1911: "Mr. Christopher E. Dixon, formerly engineer in charge of Muzo mines, personally extracted over a pound of emeralds by scratching about in one place and another.... Somondoco (sometimes called 'Chivor' from the valley near it) will soon yield gems to delight the world." 89

On June 11, 1912, Klein set out from Bogotá for Chivor to obtain samples for presentation to potential investors. ${ }^{90} \mathrm{He}$ was accompanied by Restrepo and remained at the mine until January 1913. During that time, from late October to early November 1912, an official from the German Residency in Bogotá visited the site and reported ${ }^{91}$ that within a short period of four to five weeks, the work undertaken by 15 to 20 indigenous people had produced quite favor-

${ }^{85}$ Report by the German Resident in Bogotá, Dorotheus Kracker von Schwartzenfeldt, December 21, 1911, German Federal Archive; letter from Fritz Klein, July 24, 1912, to Kracker von Schwartzenfeldt, German Federal Archive.

${ }^{86}$ Exposé der Smaragdmine "El Chivor" by Fritz Klein, undated, 16 pp., received by the German Ministry of Foreign Affairs September 13, 1913, German Federal Archive. Hermann Span (1870-1943?) and his brother Emil (1869-1944), from Reutlingen, Württemberg, Germany, moved in the 1890s to Central America and were active in Guatemala, Costa Rica, and El Salvador. Hermann Span was also involved in Colombia by 1910. Hauptstaatsarchiv Stuttgart, E40-76 Bü 1370; Diario Oficial (Colombia), 48, No. 14678 (1912), pp. 411413. Additionally, multiple notarial acts concerning Span and sundry business partners are found in the Archivo General de la Nación (Colombia).

${ }^{87}$ Escritura 1096, June 5, 1912, Notaria 2, Archivo General de la Nación (Colombia); Report by a member of the German Residency in Bogotá, Wilhelm Gerlach, November 15, 1912, German Federal Archive.

${ }^{88}$ During the 1890 s and early 1900 s, Christopher Dixon worked on behalf of the English Mining Syndicate, Limited, which operated the Muzo mine prior to the contract with the Syndicate of Muzo. Atuesta, 1899; Monthly Bulletin of the International Union of the American Republics, 8 (1900), pp. 581-582; Gaceta Judicial (Colombia), 15 (1901), pp. 169-173; Gaceta Judicial (Colombia), 16 (1903), pp. 7879; Domínguez, 1965

${ }^{89}$ Latham, 1911.

${ }^{90}$ Exposé der Smaragdmine "El Chivor" by Fritz Klein, undated, 16 pp., received by the German Ministry of Foreign Affairs September 13, 1913, German Federal Archive.

${ }^{91}$ Report by a member of the German Residency in Bogotá, Wilhelm Gerlach, November 15, 1912, German Federal Archive. 


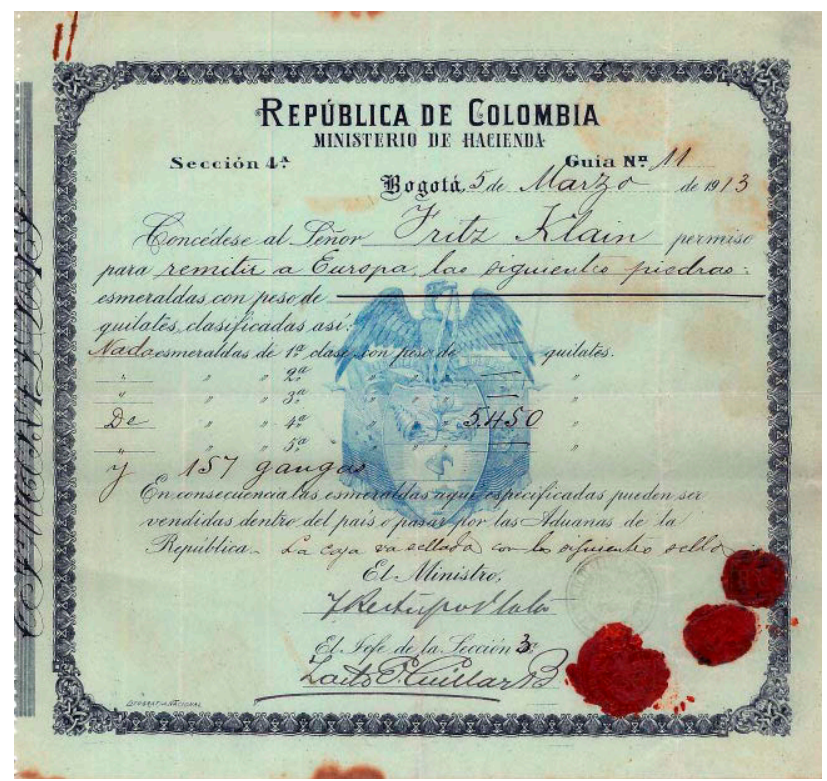

Figure 13. Export license issued to Fritz Klain [sic] by the Ministerio de Hacienda, March 5, 1913, for 157 "gangas" (emeralds in the host rock) and 5,450 carats of rough emerald crystals. Courtesy of Eduardo Restrepo Ortega.

able results. According to Klein, ${ }^{92}$ they focused for the first four months on poor targets, but when he finally understood "the direction of the veins and the character of the mine, the production of emeralds began in surprising abundance. With 20 workers, I unearthed in $3^{1 / 2}$ months under the most primitive conditions conceivable about 6,000 carats of emeralds, which have a minimum value of 150,000 marks [then equivalent to US $\$ 37,500] . "$ At the end of 1912, Klein's younger brother August arrived in Colombia for support. ${ }^{93} \mathrm{He}$ remained at the mine, together with Restrepo's younger son Alejandro, when Klein and Restrepo subsequently departed for Germany.

Klein left Bogotá in March 1913 to search for investors in Germany. With the approval of the local government, he carried a sample of emeralds produced during his approximately six months at the mine. The set consisted of 157 "gangas" (emeralds still embedded in the original host rock) and over 5,000 carats of crystals in varying sizes and shapes. ${ }^{94}$ Having received a license for exportation (figure 13), Klein wanted to use these samples to interest potential European investors. In furtherance of this mission, Klein arranged before leaving to have the term of the option contract extended, this time exclusively in his own name and without Span..$^{95}$ That extension, valid for nine months, was signed in July 1913 by several of the shareholders together with Escovar, representing Restrepo, and the attorney Dr. Antonio

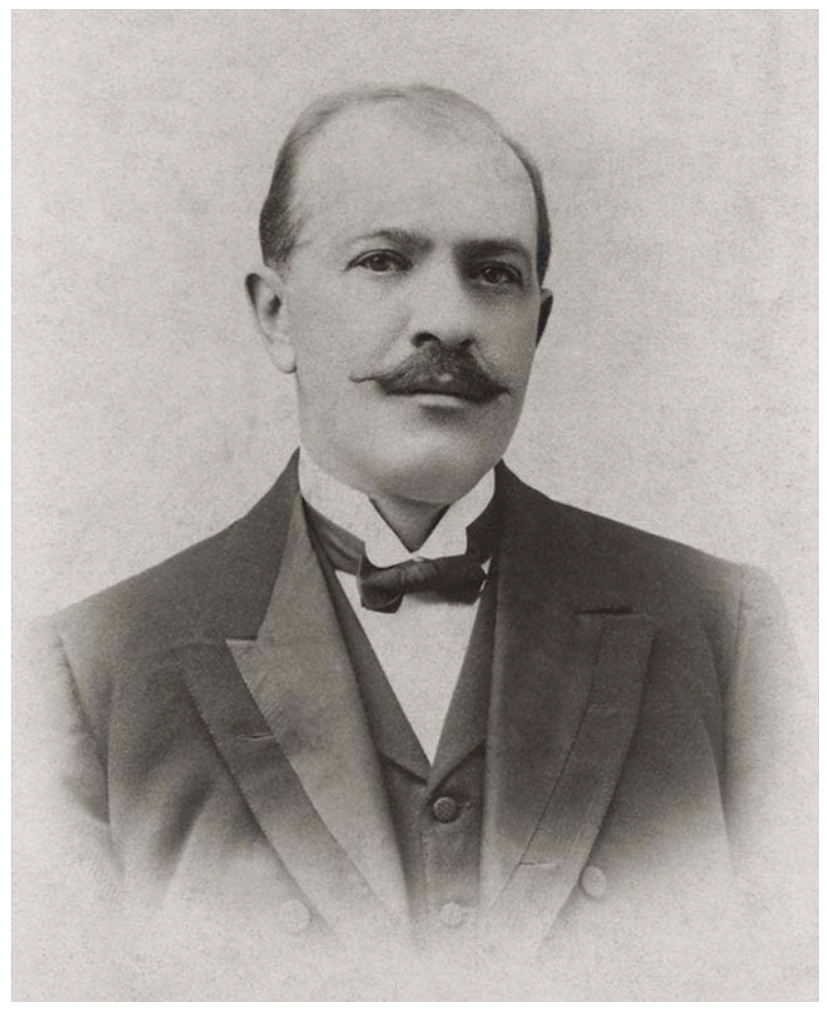

Figure 14. Dr. Antonio José Cadavid, a lawyer, law professor, and politician, filed a lawsuit on behalf of three shareholders of the Compañía de las Minas de Esmeraldas de Chivor to challenge new laws and decrees affecting the independence of the "free" emerald mines in Colombia. Cadavid also worked with Fritz Klein and the German Resident Dorotheus Kracker von Schwartzenfeldt in 1913 and 1914. Courtesy of Banrepcultural, Bogotá.

José Cadavid ${ }^{96}$ (figure 14), representing Klein. ${ }^{97}$ Word had already come to the German Residency in Bo-

\footnotetext{
${ }^{92}$ Exposé der Smaragdmine "El Chivor" by Fritz Klein, undated, 16 pp., received by the German Ministry of Foreign Affairs September 13, 1913, German Federal Archive.

${ }^{93}$ August Klein traveled from Hamburg via New York, where he arrived in October 1912. File A. Klein, List or Manifest of Alien Passengers for the United States Immigration Officer at Port of Arrival, New York, October 1912, MyHeritage.com.

${ }^{94}$ Report by a member of the German Residency in Bogotá, Josef Wipperfeld, March 27, 1913, German Federal Archive.

${ }^{95}$ Hermann Span left Colombia for Germany in August 1913 to form a banana company, apparently ending his pursuit of the Chivor emerald business. He returned to Colombia in April 1920. Diario Oficial (Colombia), 58, No. 18319-18320 (1922), p. 478.

${ }^{96}$ The lawyer, law professor, and politician Dr. Antonio José Cadavid (1866-1919) served in various positions as professor at the National University, Minister of the Treasury (1909-1910), and Minister of War (1915-1916). See Bermúdez (1966).

${ }^{97}$ Escritura 1474, July 15, 1913, Notaria 2, Archivo General de la Nación (Colombia).
} 


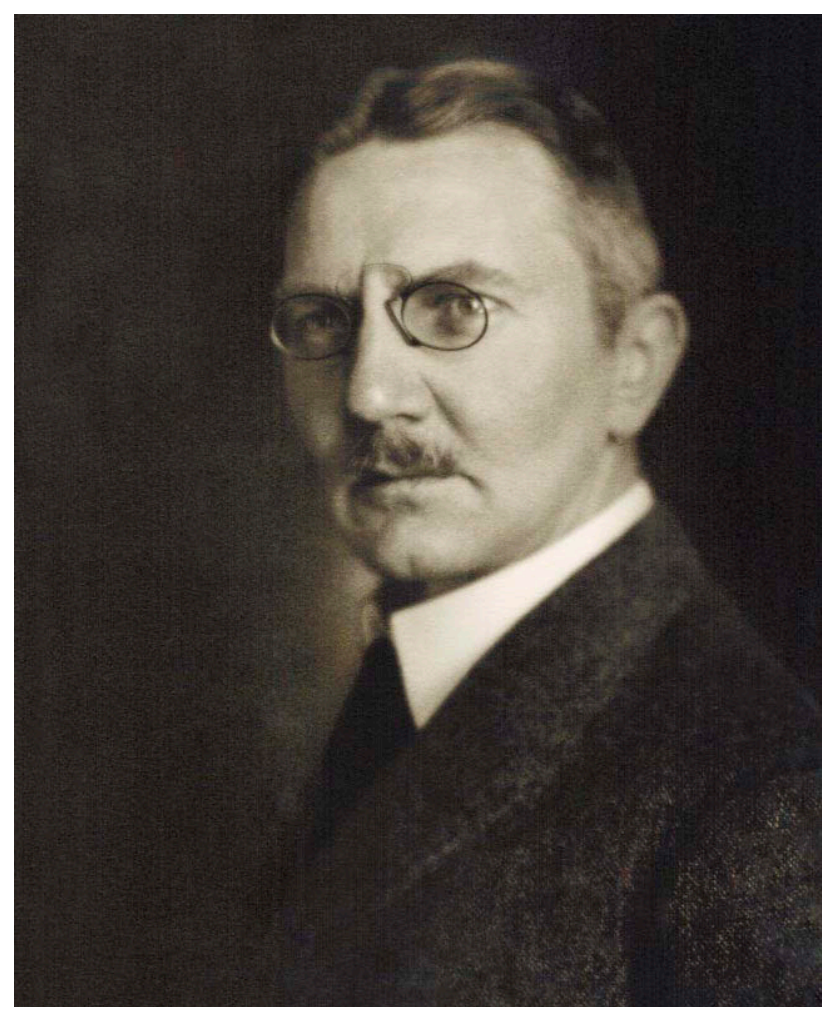

Figure 15. Dr. Hialmar Schacht served as a vice director of Dresdner Bank, one of the larger German financial institutions, from 1908 to 1915. Separate from his role at the bank, he opted in 1914 to privately invest in the Chivor mine with Fritz Klein, August Stauch, and the company Rudolph Hahn e) Sons, London, in pursuing the Chivor mine. Photo circa 1900, courtesy of Cordula Schacht.

gotá that Dresdner Bank, one of the larger financial institutions in Germany, might be interested in funding the purchase of Chivor.

Klein traveled to Germany with Restrepo, who remained there until his return in November 1913.98 Restrepo's stay in Germany included time in Idar, where he met members of Klein's family, and in Berlin, where he met Jäckh, Dr. Hjalmar Schacht (figure 15), ${ }^{99}$ and presumably other possible investors. Restrepo's sojourn incorporated a period in May 1913 at the renowned sanatorium of Karlsbad ${ }^{100}$ to restore his health. Restrepo also traveled to Meran, Tyrol, Austria, to see Klein's father August. ${ }^{101}$ Klein, in turn, traveled to England in October 1913 to show the emerald samples to members of the company Rudolf Hahn \& Sons, London, ${ }^{102}$ dealers in high-end gem materials, and other potential backers. ${ }^{103}$

Meanwhile, initial steps were taken by unknown parties between 1913 and 1914 to start a company in London under the name Emerald Mines of Somon- doco, Ltd. The stated aim of the entity was "to acquire and work the Emerald Mines called El Chivor No. 1 and El Chivor No. 2" (figure 16). The capital was to consist of $£ 90,000$, with 90,000 shares to be issued at $£ 1$ each. ${ }^{104}$ Nonetheless, no further activity pertaining to this company is known, so any underlying rival or alternate plan targeting Chivor was apparently abandoned.

Soon after Restrepo's return to Bogotá, another extension to the option contract, granting Klein exclusive rights to purchase the mine until December 1914, was signed by Cadavid, representing Klein. ${ }^{105}$

\section{LITIGATION BETWEEN MINE OWNERS AND THE COLOMBIAN GOVERNMENT (1912-1913)}

The commercial success of a gem mine depends primarily on the value of mined stones and the cost of mining operations. Also significant are the amount of duties and taxes imposed and the ability to sell the

${ }^{98}$ Restrepo traveled from Hamburg via New York, where he arrived in November 1913. File F. Restrepo, Hamburger Passagierlisten, November 1913, Ancestry.de; File F. Restrepo, List or Manifest of Alien Passengers for the United States Immigration Officer at Port of Arrival, New York, November 1913, Ancestry.com.

${ }^{99}$ Dr. Hjalmar Schacht (1877-1970) was one of the vice directors of Dresdner Bank in Berlin from 1908 to 1915. An ascendant career thereafter led him to the presidency of the German National Bank (Reichsbank), with two terms of office from 1923 to 1930 and from 1933 to 1939 . He also served concurrently as Minister of Economics from 1934 to 1937. Between 1933 and 1939 Schacht was instrumental in the financing of Hitler's rearmament, which in 1945 resulted in his indictment at the Nuremberg Trials. He was ultimately acquitted. See Kopper, 2006.

In 1909, Schacht and Klein's brother-in law Dr. Ernst Jäckh traveled together to Turkey. Following that trip and Jäckh's move to Berlin in 1912, they cooperated on many political projects. After Jäckh's emigration in 1933 and Schacht's new engagement, however, their ways parted.

${ }^{100}$ Karlsbader Kurliste, No. 135, May 23, 1913, 2 pp.

${ }^{101}$ Letters by Fritz Klein, November 27, 1913, and January 26, 1914, to Restrepo; Letter from August Klein Senior, December 27, 1913, to Restrepo.

${ }^{102}$ The company Rudolf Hahn \& Sons, London, dated back to 1893 and in 1914 was managed by the brothers Eugen and Paul Hahn. The Hahn brothers had roots in Idar, Germany, and were cousins of August Hahn, brother-in-law of Fritz and August Klein. August Hahn married Klein's younger sister Luise (1884-1976).

${ }^{103}$ Letter from Rudolf Hahn \& Sons, London, November 7, 1913, to the mine owners.

${ }^{104}$ Prospectus, Emerald Mines of Somondoco, Ltd., Undated. Although the prospectus and attendant documents are undated, references therein to several specific individuals (e.g., Diódoro Sánchez as president of the Sociedad Colombiana de Ingenieros and Francisco Restrepo Plata as Ministro de Hacienda, Colombia) enable preparation and publication of the material to be placed within the 1913 to 1914 timeframe.

${ }^{105}$ Escritura 2759, December 24, 1913, Notaria 2, Archivo General de la Nación (Colombia). 


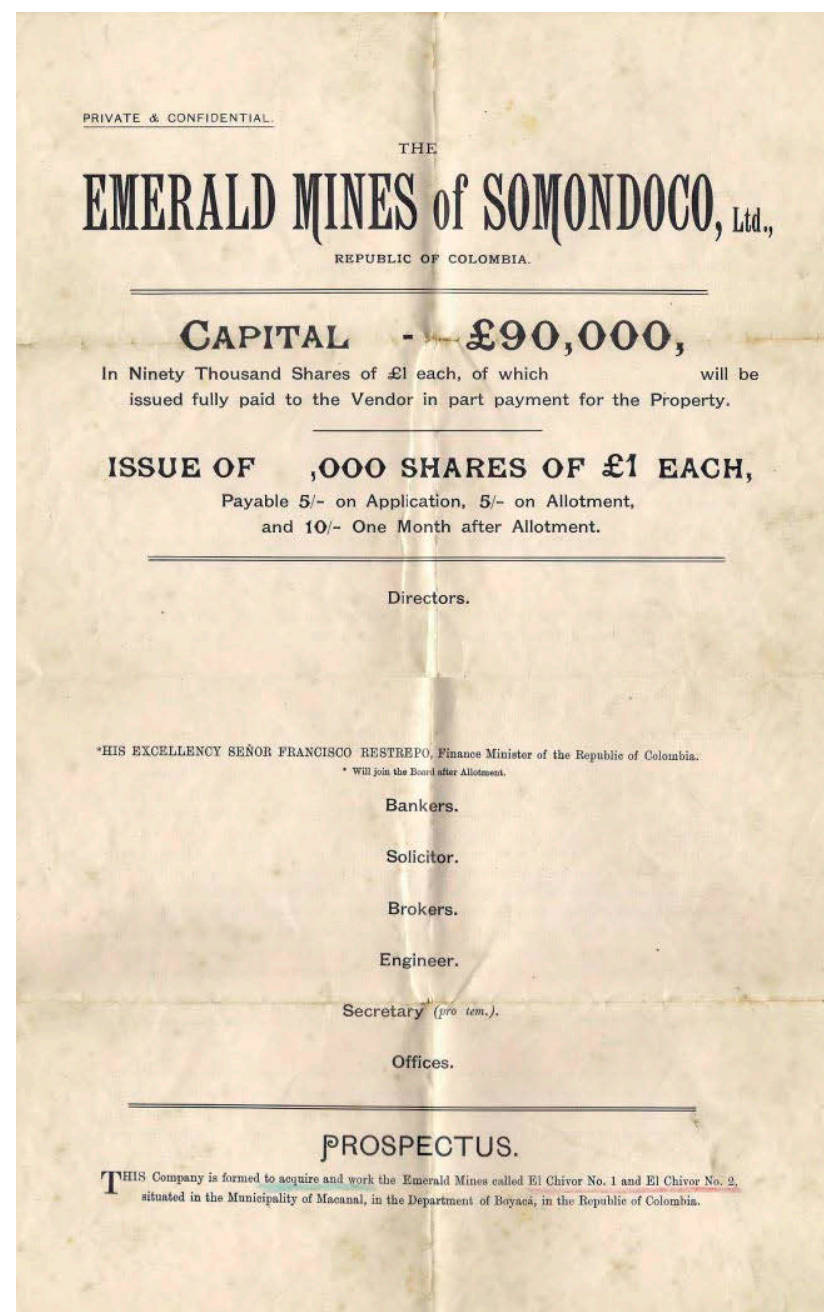

Figure 16. Prospectus drafted in 1913-1914 to form a company in London under the name Emerald Mines of Somondoco, Ltd., "to acquire and work the Emerald mines called El Chivor No. 1 and El Chivor No. 2." Courtesy of Eduardo Restrepo Ortega.

gems on the open market. During relevant periods in Colombia, the applicable framework of various laws and decrees, issued at different times and subsequently incorporating multiple addendums and amendments, was rife with complexity. The major emerald mines of Muzo and Coscuez had belonged to the government since 1886 , but a number of mostly smaller mines existed under private ownership. After 1905, however, registration of new emerald mines by private owners was no longer permitted and additional taxes were imposed upon the existing mines (Law No. 40 of 1905).

Prior to the 1905 change in regulations, a provision allowed for the annual taxes on privately owned mines to be paid in advance for a period of 20 years.
Thereafter, these so-called free mines were to be forever excluded from any taxes and fees and could no longer be registered by other persons (Law No. 292 of 1875, Article 45, adapted in Law No. 38 of 1887). ${ }^{106}$ As noted previously, the taxes for Chivor 1 and 2 had been paid in advance for 20 years.

After the law changed, the nature of the rights afforded to the free mines became a subject of repeated controversy and litigation between the mine owners and the Colombian government. The disputes centered on three issues:

1. Taxes and fees payable by the owners of free mines

2. Control of mining operations by the government

3. Control of emerald sale and export by the government

An initial legal action challenging several laws and decrees was filed by Francisco de P. Matéus in his name and on behalf of several other owners of free mines. The eventual decision of the Corte Suprema de Justicia on August 2, 1912, was a partial victory for the mine owners, ruling that governmental control of the mining operations was illegal but that state control of emerald exportation could continue. ${ }^{107} \mathrm{~A}$ copy of the decision was mailed to Guateque to inform Restrepo and Klein, who were working at Chivor at the time.

In October 1912, the government rejected a complaint by Dixon about restrictive rules circumscribing the emerald mining business after a sevenyear dispute that had begun in 1905 (again, see box A). ${ }^{108}$

A new decree by the Colombian government was then issued in December 1912, followed by a supplement in January 1913, which sought again to increase control by governmental institutions over free mines. Opposition to the new regulations began immediately, with a petition by Isaza, shareholder in the Compañía de las Minas de Esmeraldas de Chivor,

\footnotetext{
${ }^{106}$ Bullman, 1892.

${ }^{107}$ Corte Suprema de Justicia, Bogotá, agosto 2 de 1912, "Sobre la inexequibilidad de algunas disposiciones relacionadas con la explotación de minas de esmeraldas [About the unenforceability of some decrees related to the exploitation of emerald mines]," 21 pp.; Gaceta Judicial (Colombia), 22 (1913), pp. 2-9.

${ }^{108}$ Letter from Christopher Dixon, November 10, 1905, to the Ministerio de Relaciones Exteriores, Ministerio de Industrias, Archivo, Correspondencia 1905, Archivo General de la Nación (Colombia); Diario Oficial (Colombia), 48, No. 14720 (1912), pp. 812-813; Annual report on Colombia for the year 1913.
} 


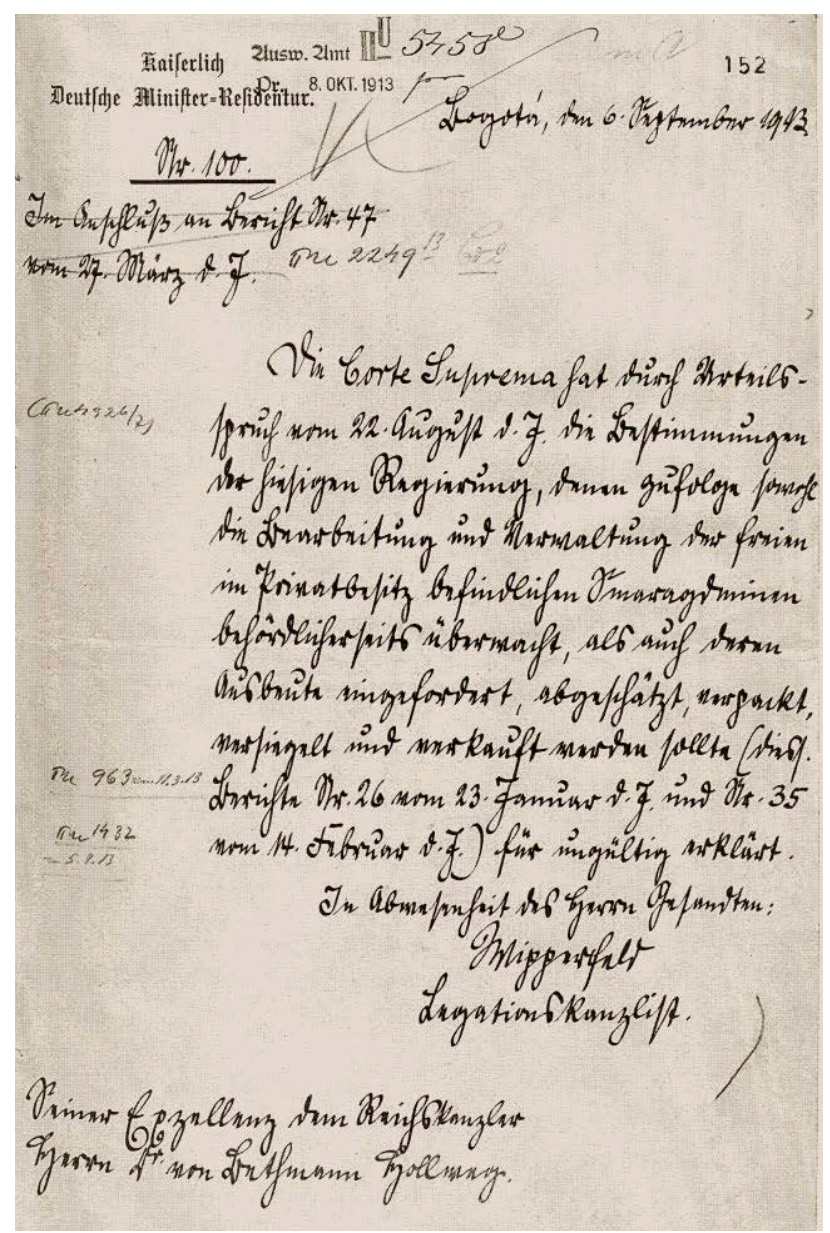

Figure 17. Report from a member of the German Residency in Bogotá, Josef Wipperfeld, to the German Ministry of Foreign Affairs, Berlin, dated September 6, 1913. The report briefly described the August 22 decision by the Colombian Corte Suprema de Iusticia addressing privately owned "free" mines. Historical Archive of the German Ministry of Foreign Affairs.

to the Minister of Finance in January $1913^{109}$ and a similar petition by Klein in February 1913. ${ }^{110}$ An additional legal action challenging several of the older laws and decrees and the two new decrees was filed on February 22, 1913, by the attorney Cadavid in the names of three Compañía de las Minas de Esmeraldas de Chivor shareholders (the Colombian citizens Isaza, Escovar, and González). ${ }^{111}$ The decision of the Corte Suprema de Justicia, issued August 22, 1913, nullified several of the contested laws and decrees, ruling that the free emerald mines could work without any further governmental control. ${ }^{12}$ That result (figure 17) was telegraphed to the Ministry of Foreign
Affairs in Berlin by the German Resident in Bogotá on September 7, 1913, and Klein was promptly informed via his brother-in-law Jäckh.

\section{ACTIVITIES IN 1914}

After the favorable resolution of the legal situation in Colombia, Klein was able to continue searching for and negotiating with potential investors. In this endeavor, Jäckh and his contacts with political and business elites once again proved instrumental. Restrepo, as indicated above, had already returned to Colombia.

The search culminated on February 14, 1914, with the founding of the Syndikat El Chivor (Syndicate El Chivor, used hereinafter) between four members, with initial capital contributions as follows: ${ }^{113}$ August Stauch (figure 18), ${ }^{114}$ Berlin-Zehlendorf, 25,000 marks; Dr. Hjalmar Schacht, Berlin-Zehlendorf, 10,000 marks; Rudolf Hahn \& Sons, London, 10,000 marks; and Fritz Klein, Idar, 5,000 marks. The founding contract further contained provisions addressing usage of the initial capital, investigation of the property by an expert, and terms of any future purchase of the mine. The services of an expert were considered necessary because the quality of Klein's samples was inadequate to convince all investors to formalize the purchase, absent independent examination of the mine (figure 19). ${ }^{115}$ In these endeavors, the four members agreed that the company should be privately financed, without institutional funding from Dresdner Bank or any other German banking firm.

\footnotetext{
${ }^{109}$ Diario Oficial (Colombia), 49, No. 14823 (1913), pp. 341-342.

${ }^{110}$ lbid., pp. 546-548.

${ }^{111} \mathrm{All}$ four Colombians involved were well-known lawyers who had held high-level positions in Colombia as university professors, diplomats, and ministers. As previously noted, Enrique González also formerly served as director of operations at the Muzo emerald mine. Diaz, 1967.

${ }^{112}$ Gaceta Judicial (Colombia), 22 (1913), pp. 242-244; Cadavid, 1913.

${ }^{113}$ Historical Archive of the German Ministry of Foreign Affairs; Prof. Robert Scheibe collection, University Library Freiburg.

${ }^{114}$ August Stauch (1878-1947) has been recognized as the discoverer of the diamond deposits in Namibia, then known as German SouthWest Africa, in 1908. Diamond mining made him and those involved in his Colonial Mining Company extremely wealthy. Stauch bought farms in southwest Africa and a villa in Berlin-Zehlendorf, Germany. In the 1920s, he was active as an investor not only in a variety of mining companies but also in technology-focused enterprises. See Levinson, 2007. The Schacht and Stauch families lived near each other in Berlin-Zehlendorf, Germany, and might thus have interacted on a personal level as well.

${ }^{115}$ Letter from Rudolf Hahn \& Sons, London, November 7, 1913, to
} the mine owners. 


\section{EMERALDS FROM THE CHIVOR MINING DISTRICT, COLOMBIA}

Emeralds from the Chivor region are found as individual single crystals (A-C) or as crystal aggregates (D-F). These aggregates consist of parallel or subparallel oriented crystals or even of radiating, strongly inclined individuals. The habit of the emerald crystals is formed by six or twelve hexagonal prism faces in combination with two basal pinacoids (A-C, G-J). Occasionally, different hexagonal dipyramids are also seen (I and M). The basal pinacoid might show incomplete growth surfaces (K), and, in extreme rare cases, cavities parallel to the hexagonal crystal axis are seen (L). The mineral assemblage within the emerald-bearing veins at Chivor consists of pyrite $(\mathrm{A}-\mathrm{C}, \mathrm{N}-\mathrm{R})$ frequently associated with albite (var. cleavelandite), calcite, dolomite $(\mathrm{O}-\mathrm{R})$, occasionally quartz, and limonite (mainly goethite) formed by the alteration of pyrite. The host rocks of the Chivor deposit are breccia, layered limestones, albitites, and black and gray shales (C-K, M-S). Photos by G. Martayan, Paris.

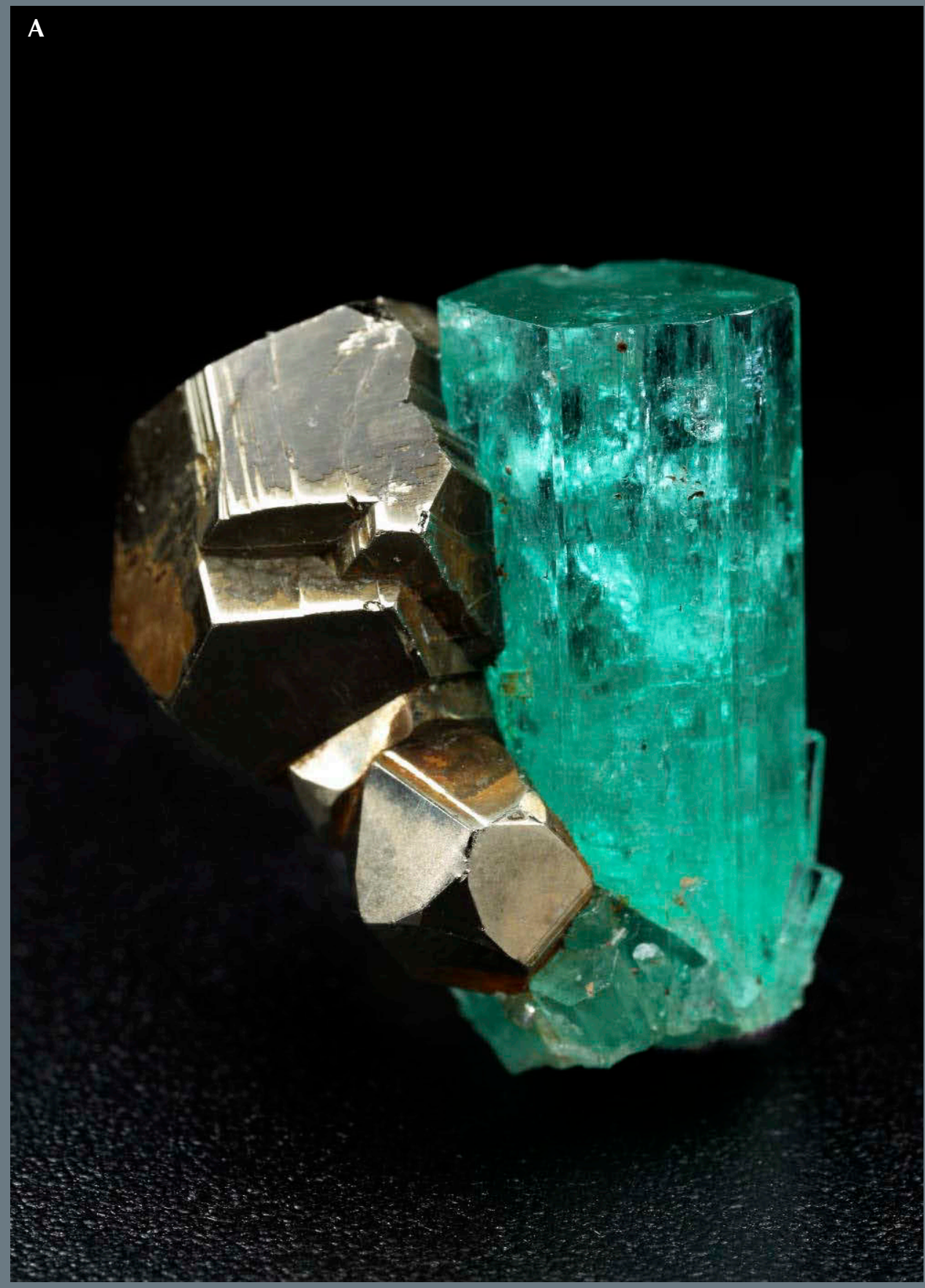

Emerald crystal: $19 \times 7.5 \mathrm{~mm}$

Habit: hexagonal prism faces terminated by flat basal pinacoids; the large beryl crystal is intergrown at different angles with smaller crystals

Associated minerals: dodecahedral pyrite crystals 

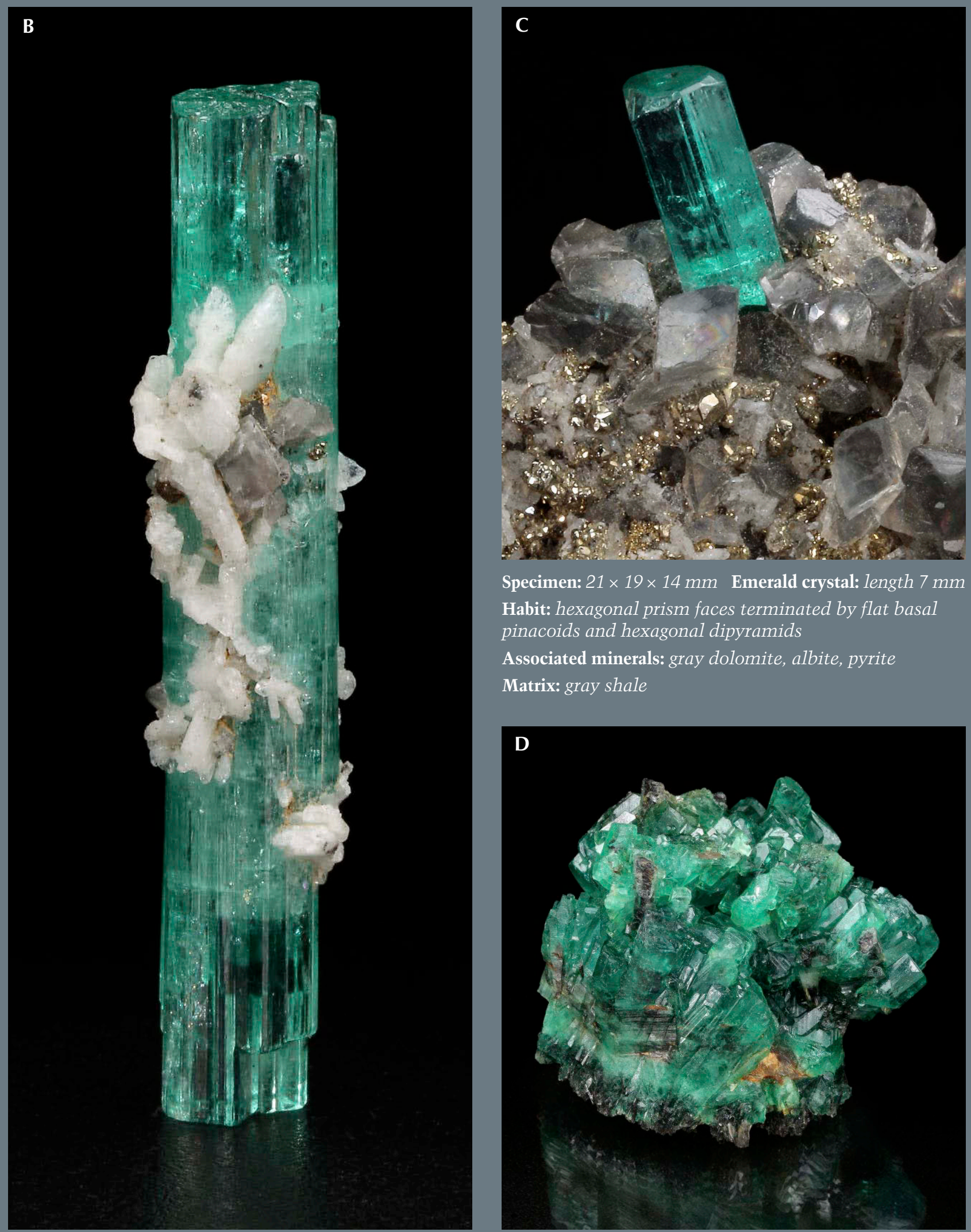

Specimen: $21 \times 19 \times 14 \mathrm{~mm}$ Emerald crystal: length $7 \mathrm{~mm}$ Habit: hexagonal prism faces terminated by flat basal pinacoids and hexagonal dipyramids

Associated minerals: gray dolomite, albite, pyrite Matrix: gray shale

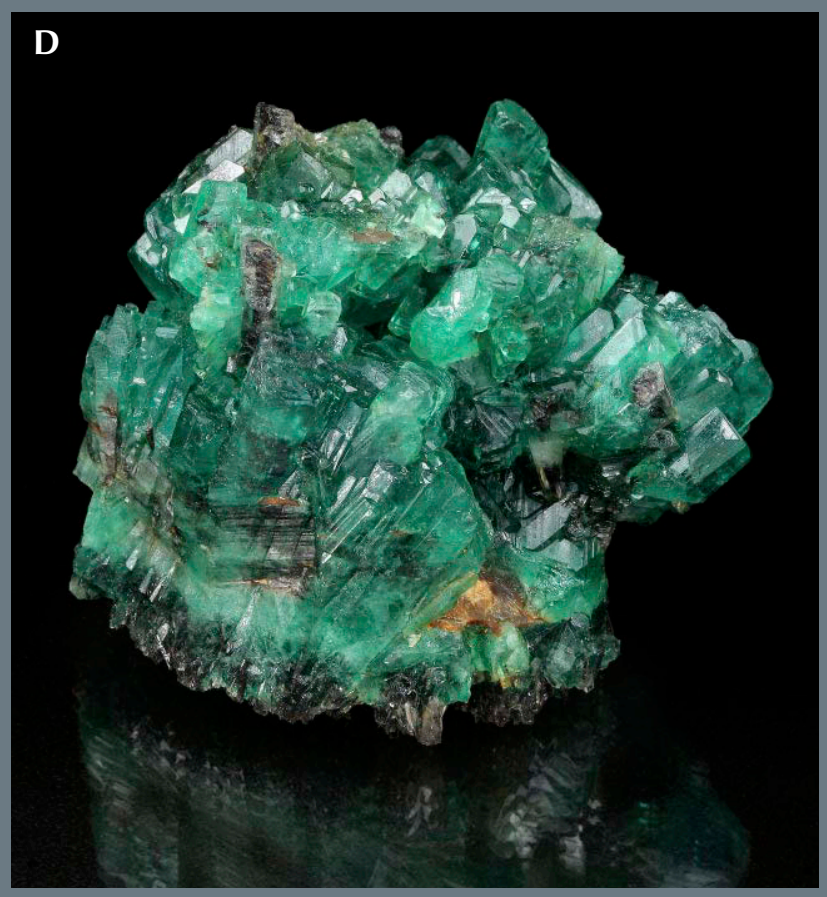

Emerald crystal: length $33 \mathrm{~mm}$

Habit: hexagonal prism faces terminated by flat basal pinacoids

Associated minerals: albite, pyrite, calcite

Cluster of intergrown emerald crystals, specimen: $43 \times 38$ $\times 36 \mathrm{~mm}$; several crystals exhibit striations (growth patterns) on basal pinacoids or on prism faces; some crystals of the aggregate contain carbonaceous inclusions Associated minerals: limonite 


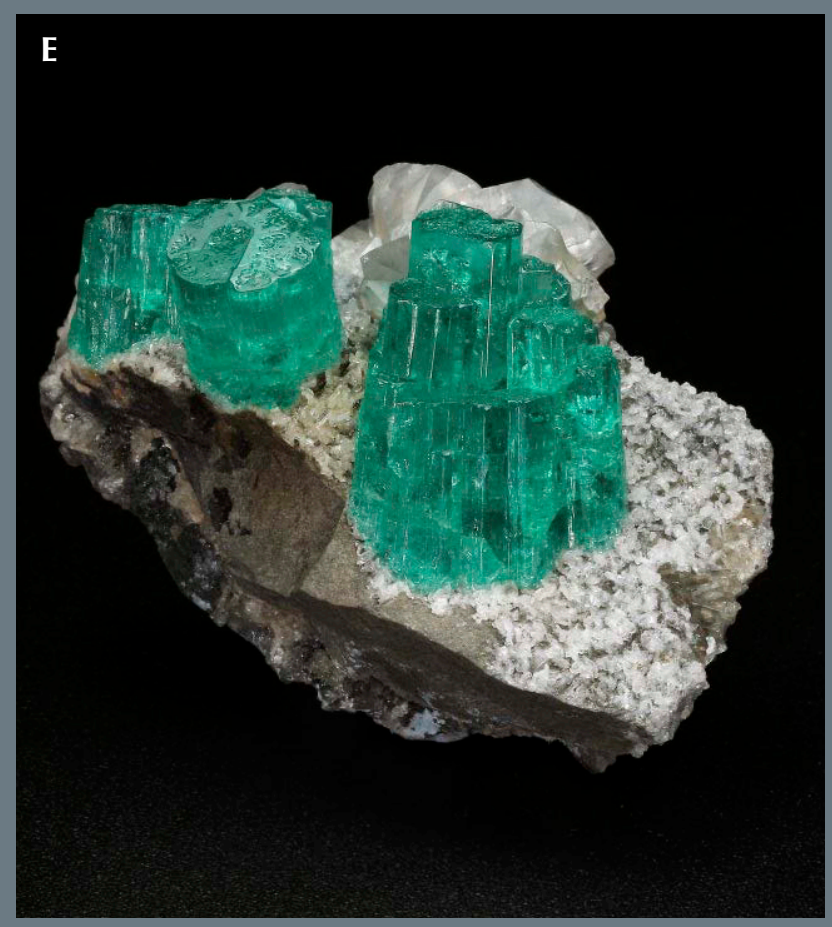

Specimen with emerald clusters: $45 \times 33 \times 23 \mathrm{~mm}$, largest cluster: $18 \times 16 \mathrm{~mm}$

Associated minerals: dolomite, albite, pyrite

Matrix: gray shale

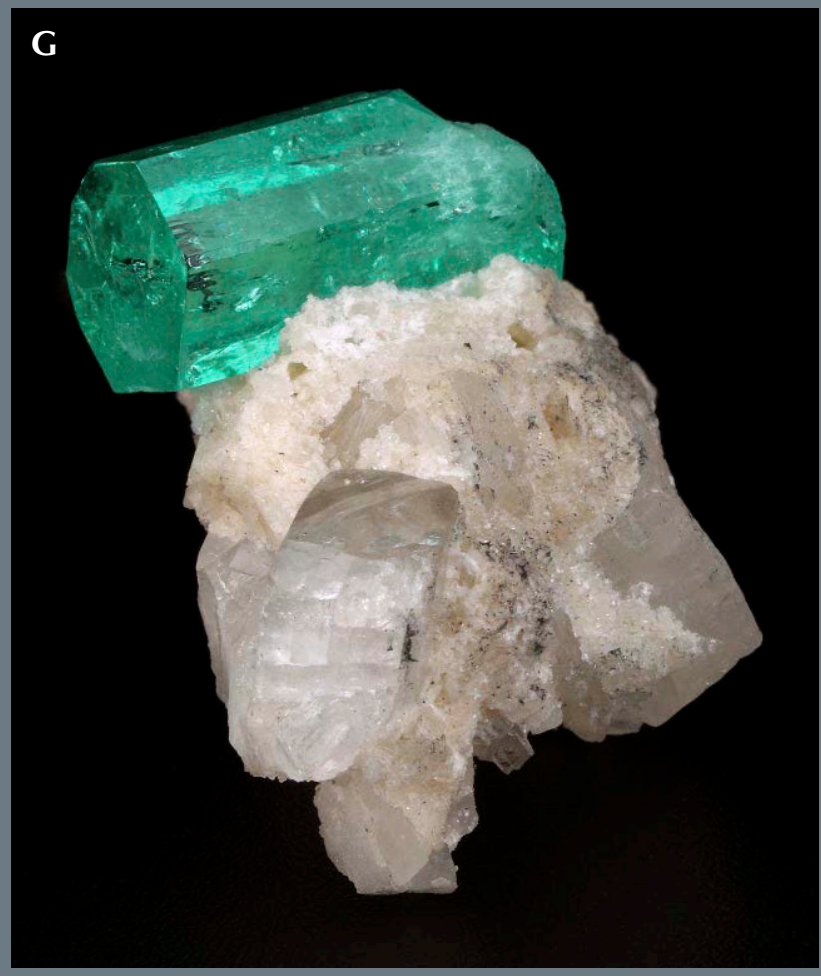

Specimen with emerald crystal Crystal: length $8 \mathrm{~mm}$ Habit: hexagonal prism faces terminated by flat basal pinacoids and hexagonal dipyramids Associated minerals: pyrite, dolomite Matrix: breccia

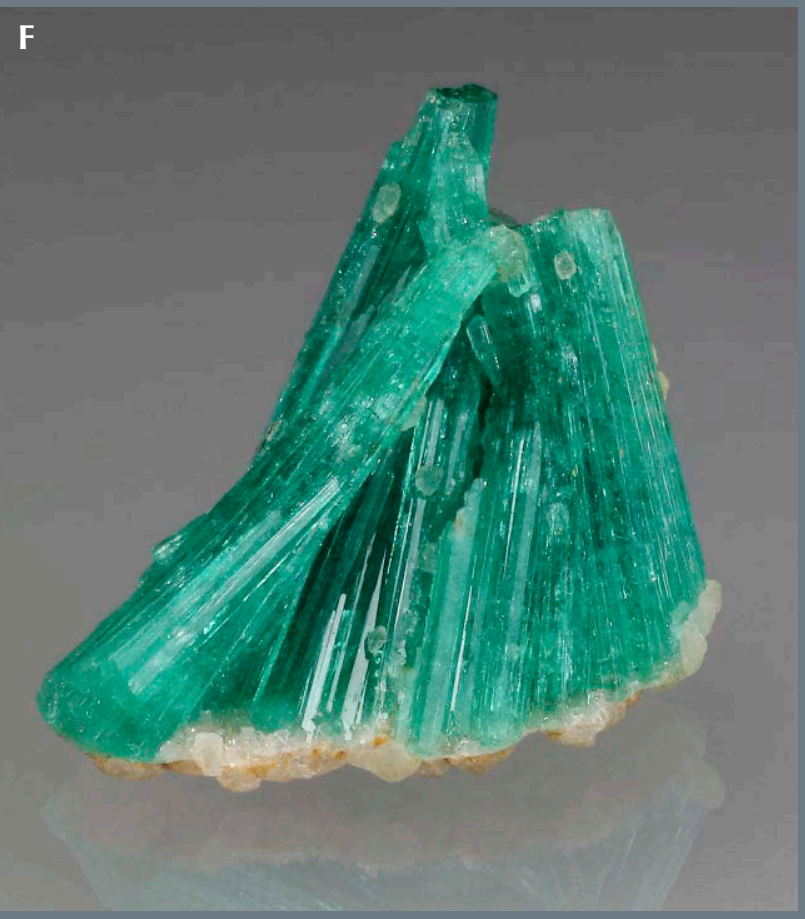

Emerald cluster, specimen: $20 \mathrm{~mm}$ across; the crystals of the aggregate are inclined to each other

Associated minerals: albite

\section{H}

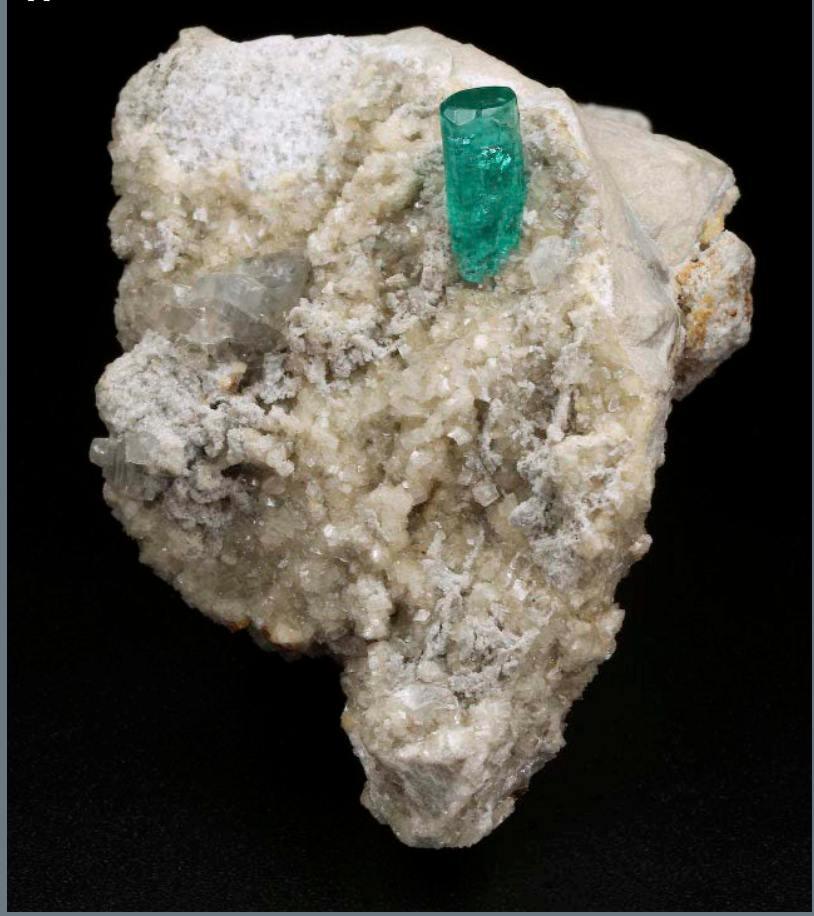

Specimen with emerald crystal Crystal: $11 \times 4.5 \mathrm{~mm}$

Habit: hexagonal prism faces terminated by flat basal pinacoids and hexagonal dipyramids

Associated minerals: white albite, pyrite, dolomite

Matrix: gray limestone 


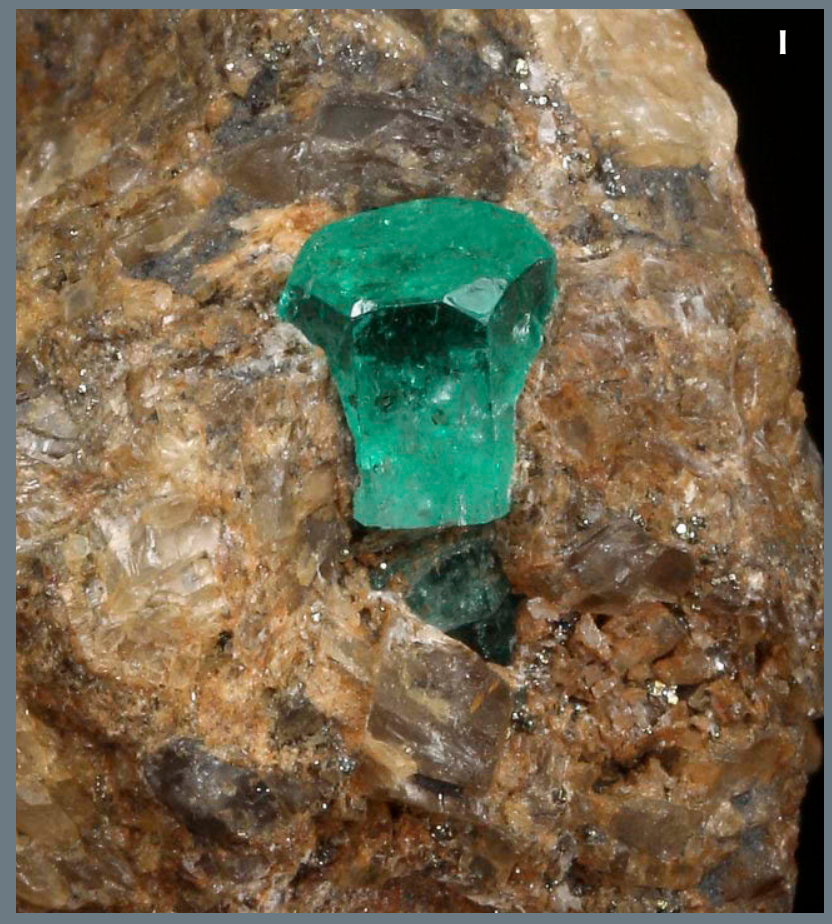

Specimen with emerald crystal Crystal: length $8 \mathrm{~mm}$

Habit: hexagonal prism faces terminated by flat basal pinacoids and hexagonal dipyramid

Associated minerals: pyrite, dolomite

Matrix: breccia

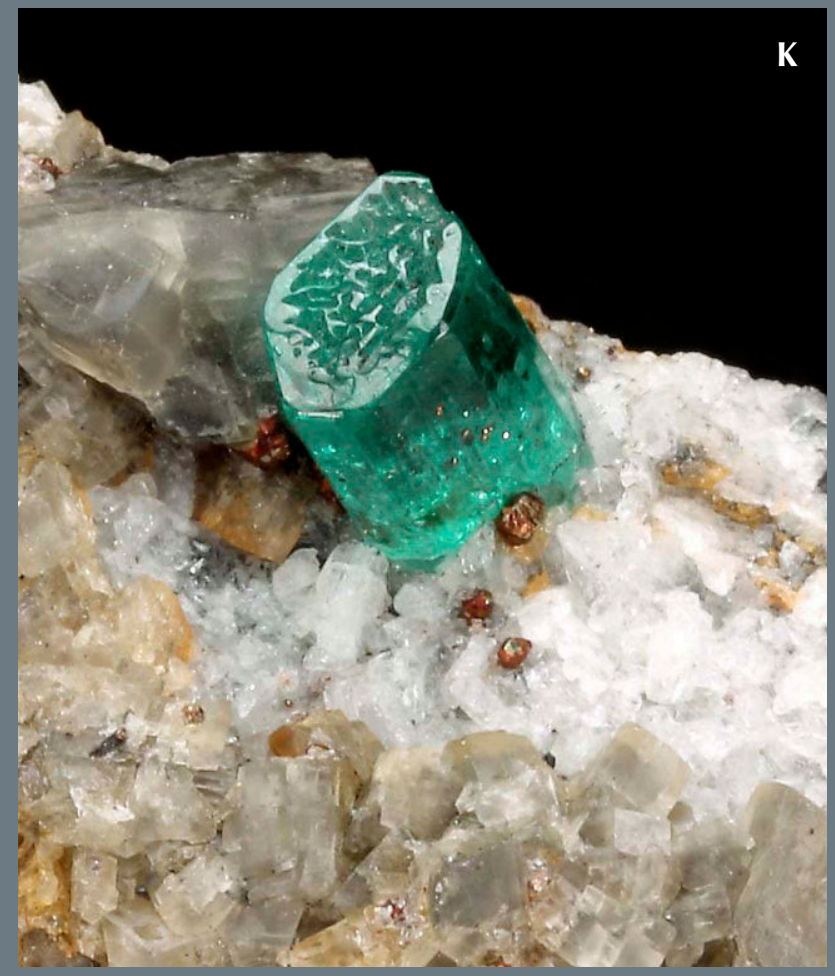

Specimen with emerald crystal Crystal: length $5 \mathrm{~mm}$

Habit: hexagonal prism faces terminated by flat basal pinacoids, indentations in the basal pinacoid

Associated minerals: gray calcite rhombs, white albite, pyrite

Matrix: black shale

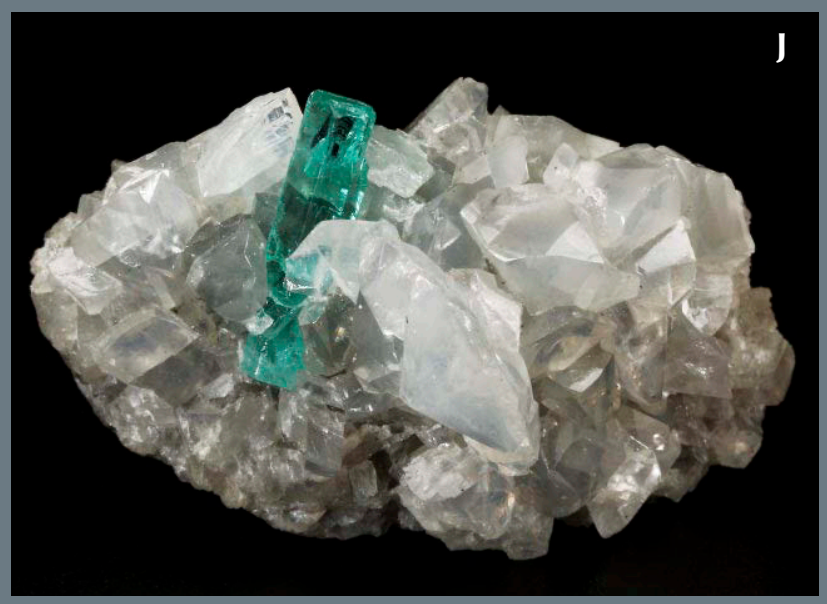

Specimen with emerald crystal Crystal: length $13 \mathrm{~mm}$ Habit: hexagonal prism faces terminated by flat basal pinacoids

Associated minerals: pyrite, gray dolomite rhombs Matrix: gray shale

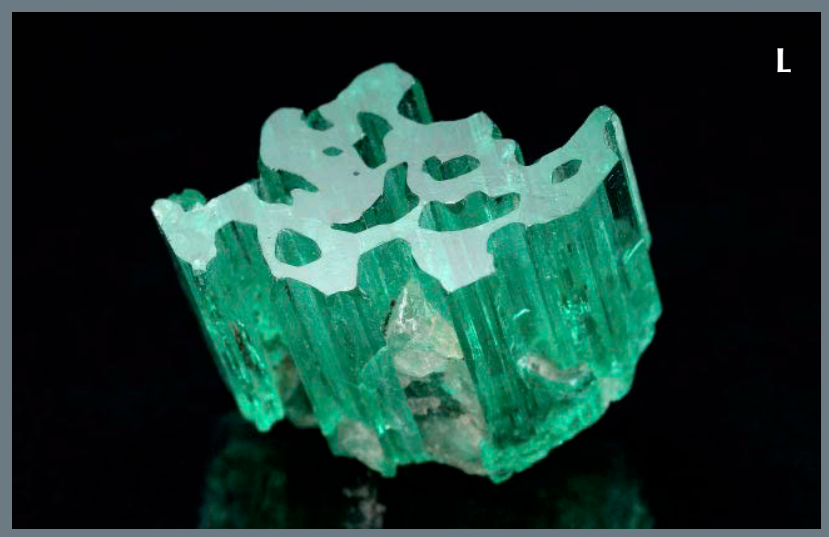

Emerald crystal with channels parallel to the c-axis

Specimen: $17 \times 11 \times 11 \mathrm{~mm}$

Associated minerals: gray dolomite

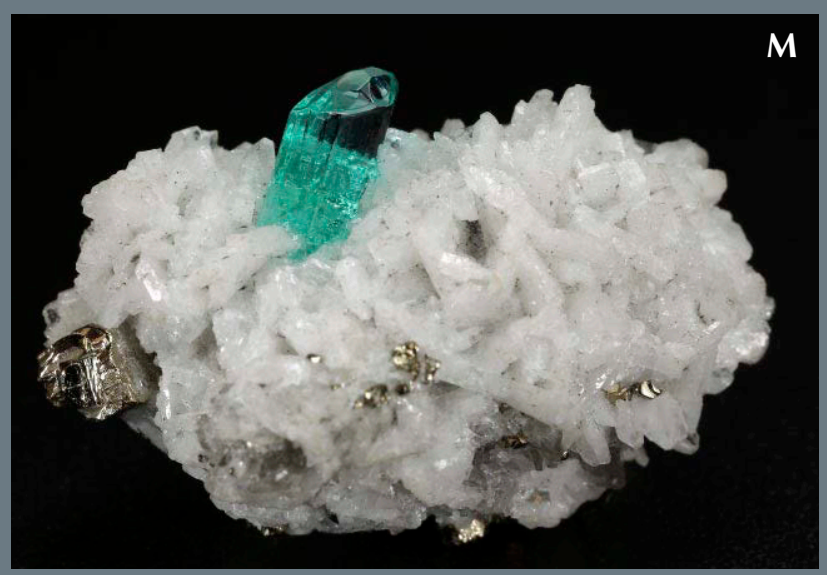

Specimen with emerald crystal Crystal: length $6 \mathrm{~mm}$

Habit: hexagonal prism faces terminated by flat basal pinacoids and hexagonal dipyramids

Associated minerals: white albite 


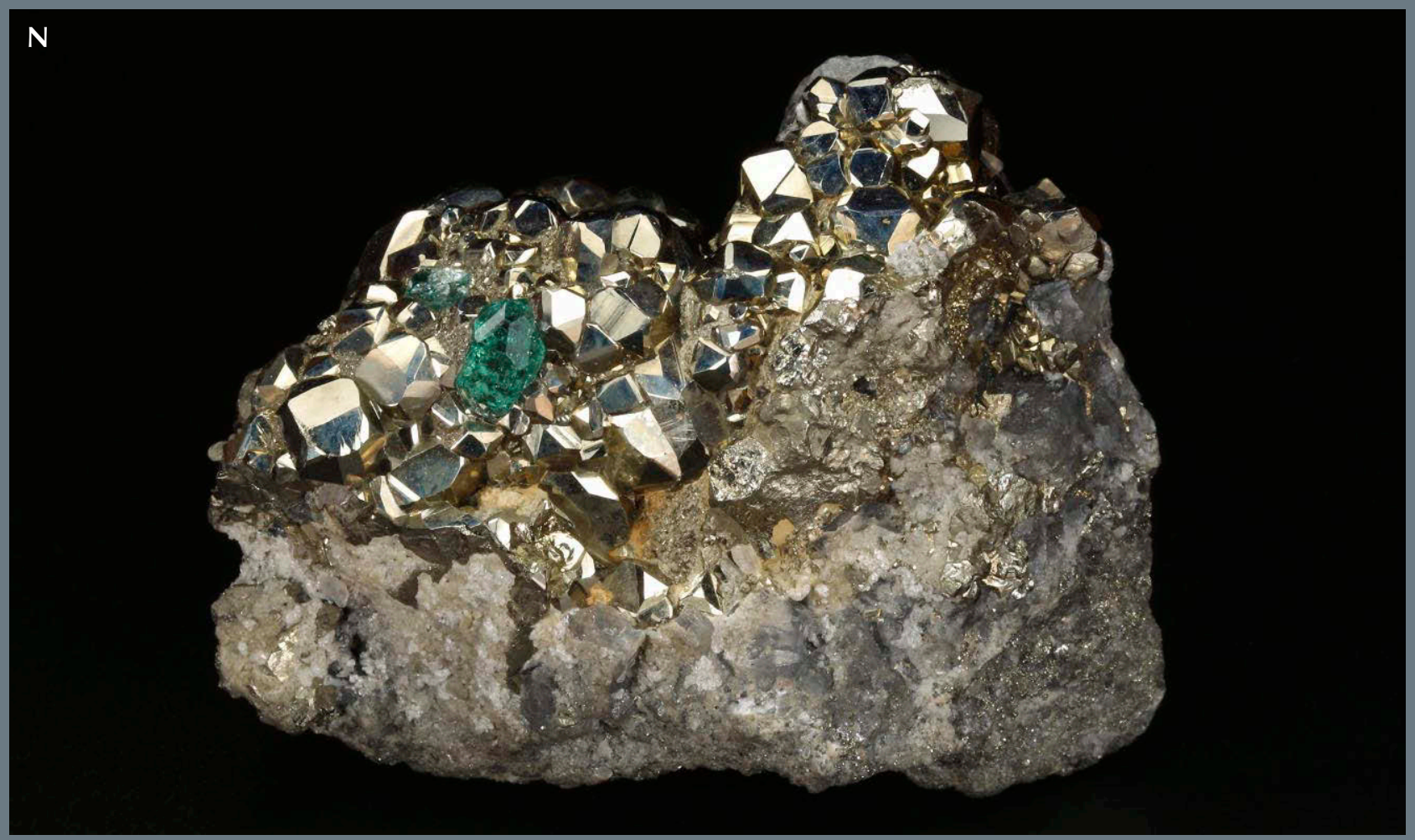

Specimen: $60 \times 45 \times 55 \mathrm{~mm}$ Emerald crystal: length $6 \mathrm{~mm}$

Habit: hexagonal prism faces terminated by flat basal pinacoids and hexagonal dipyramids Associated minerals: pyrite, dolomite Matrix: black shale

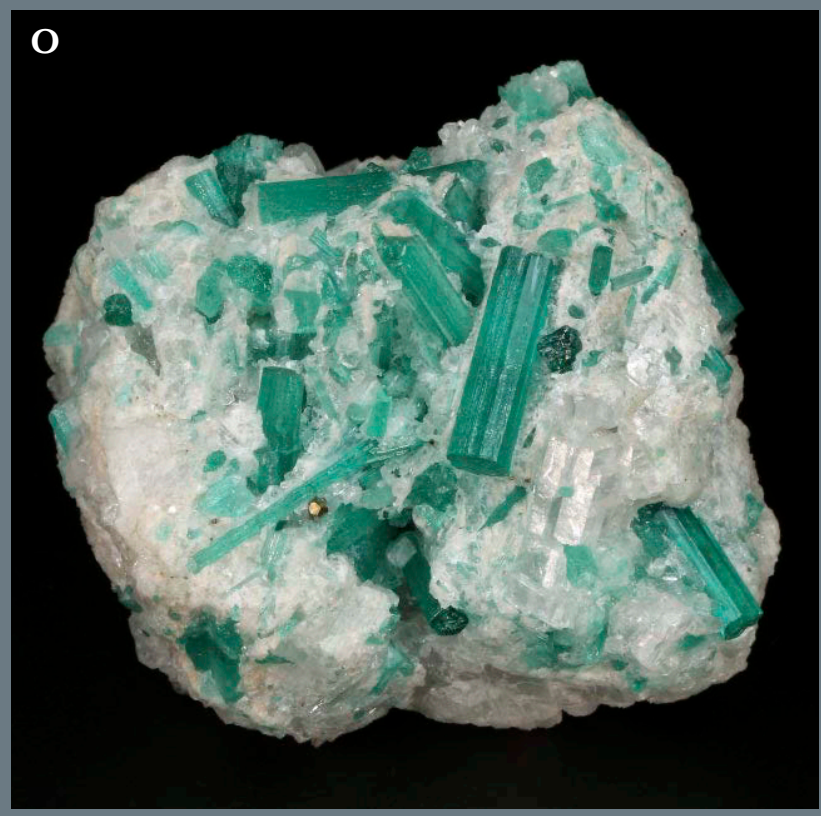

Specimen: $42 \mathrm{~mm}$ across Emerald crystals: up to $14 \mathrm{~mm}$ in length

Habit: hexagonal prism faces terminated by flat basal pinacoids, prism faces with striations parallel to the $c$ axis

Associated minerals: dolomite, pyrite, embedded in a white dolomitic matrix

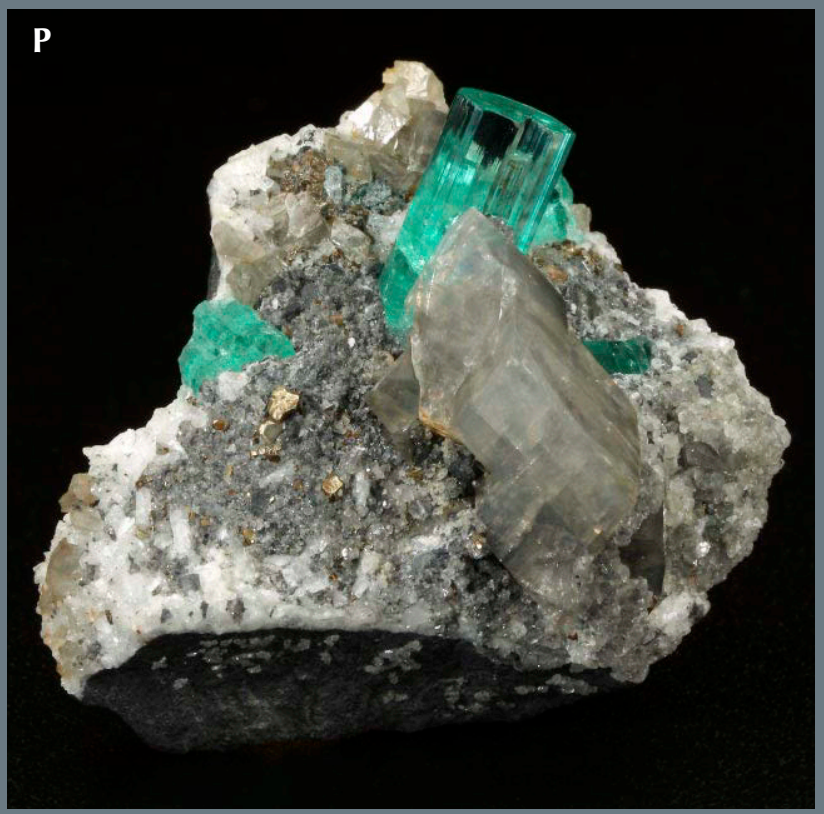

Specimen: $32 \mathrm{~mm}$ across Emerald crystal: length $9 \mathrm{~mm}$ Habit: hexagonal prism faces terminated by flat basal pinacoids

Associated minerals: pyrite, gray dolomite rhombs, white albite

Matrix: black shale 


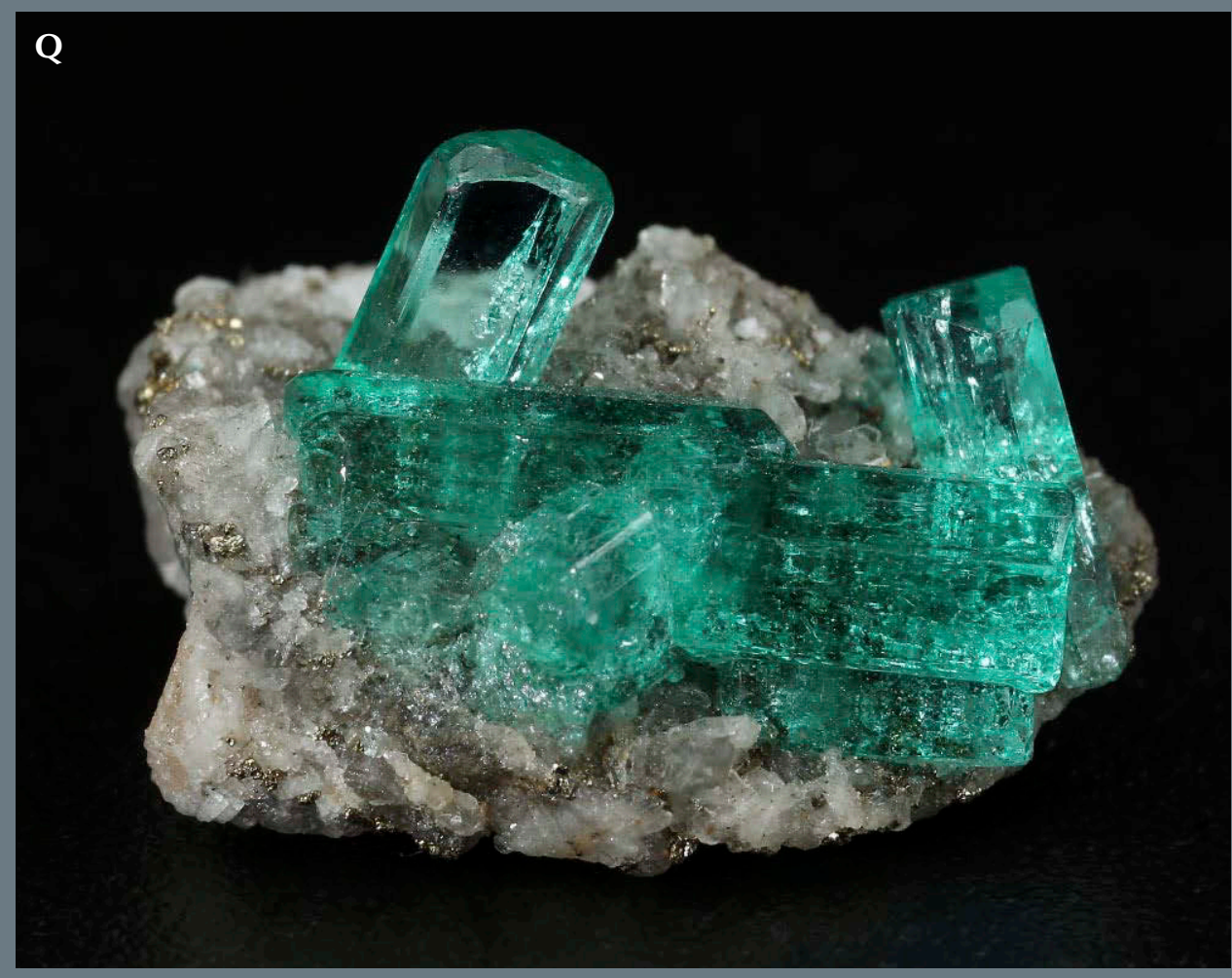

Specimen: $15 \times 12 \times 5 \mathrm{~mm}$ Largest emerald crystal: length $11 \mathrm{~mm}$

Habit: hexagonal prism faces terminated by flat basal pinacoids and hexagonal dipyramids

Associated minerals: white albite

Matrix: gray shale
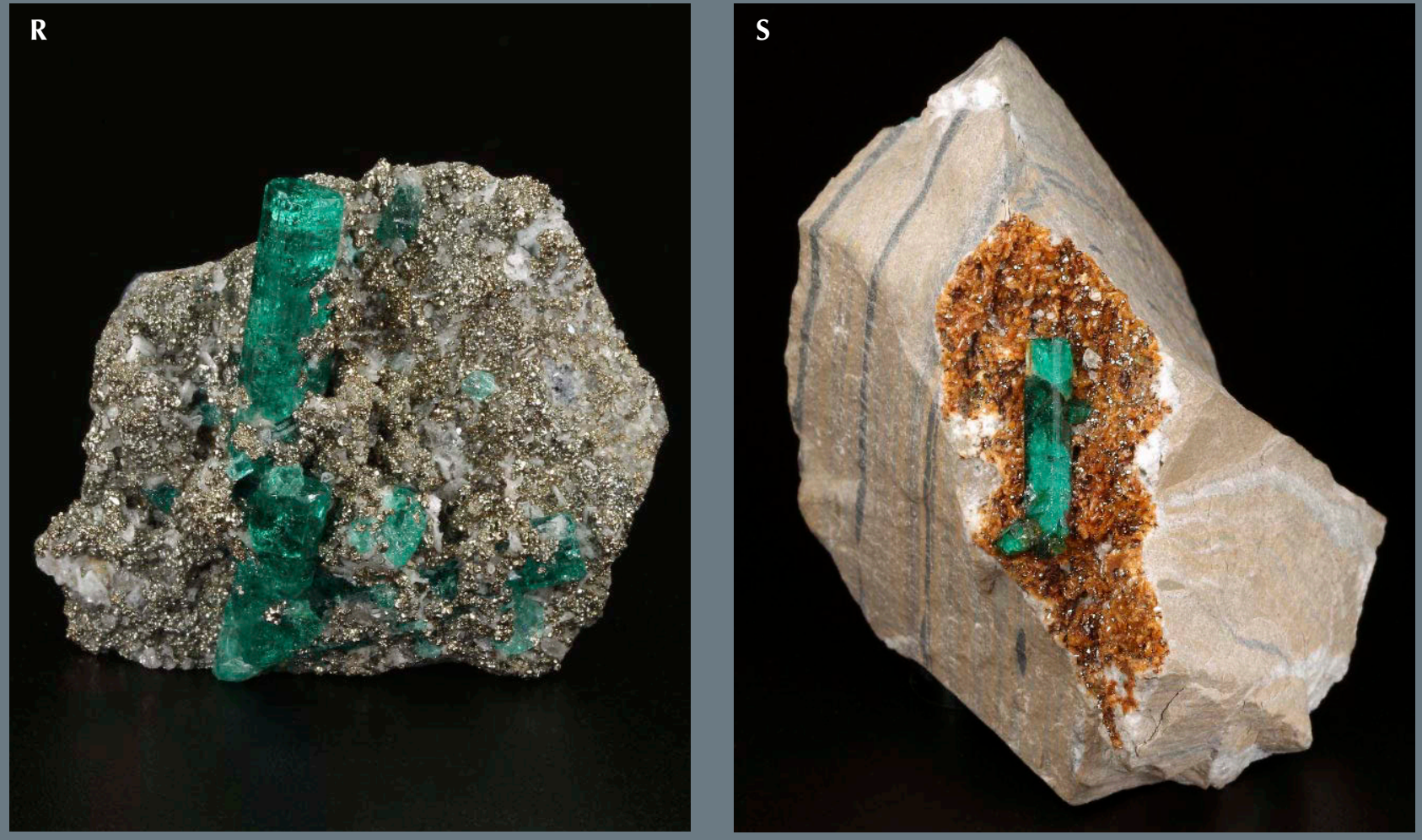

Specimen: $38 \times 35 \times 18$ mm Emerald crystal: length 20 $\mathrm{mm}$

Specimen: $67 \times 50 \times 50 \mathrm{~mm}$ Emerald crystal: length 18 mm

Habit: hexagonal prism faces terminated by flat basal pinacoids and hexagonal dipyramids

Associated minerals: albite, dolomite, small pyrite nodules Matrix: layered gray limestone 


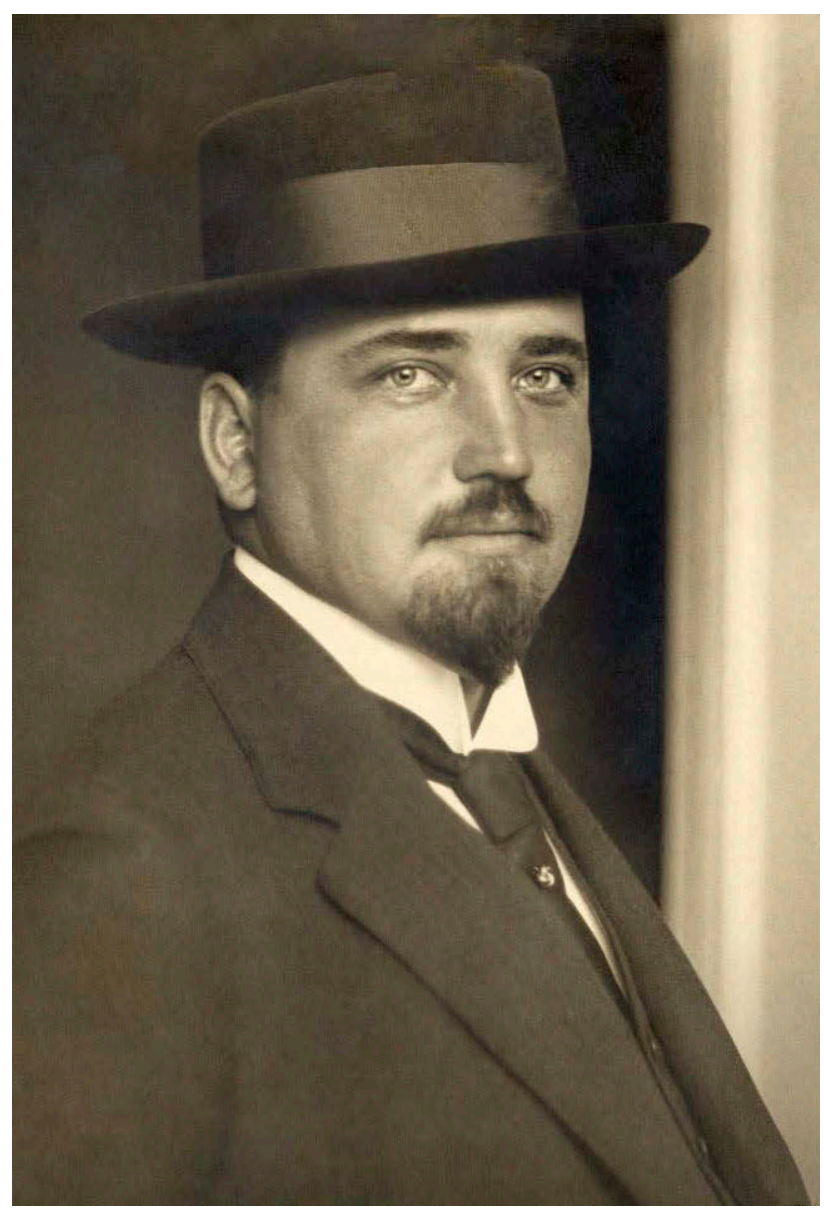

Figure 18. August Stauch is credited with discovering the diamond deposits in Namibia in 1908. Stauch was a key investor in the group assembled by Fritz Klein in 1914 to pursue the Chivor mine. Photo 1921, courtesy of Dr. Gabriele Schneider.

The initial paid-in capital was to be used solely to finance the expert evaluation. Klein was to assist the scientific expert in his activities. Any subsequent purchase of the mine would proceed through exercise of Klein's option by paying the price of $£ 51,000$ (equivalent to $1,020,000$ marks and identical to the 255,000 pesos oro specified in the option contract). Klein was to receive 1,250,000 marks cash from the investors to purchase the mine and would be entitled to 20 percent of the shares of a future mining company.

As communicated in a letter from the Syndicate El Chivor dated February 16, 1914, ${ }^{116}$ Prof. Robert Scheibe (figure 20), ${ }^{117}$ professor of geology at the Royal Mining Academy (Königliche Bergakademie) in Berlin and close friend of Stauch, was selected to perform the expert evaluation of the Chivor mine. A

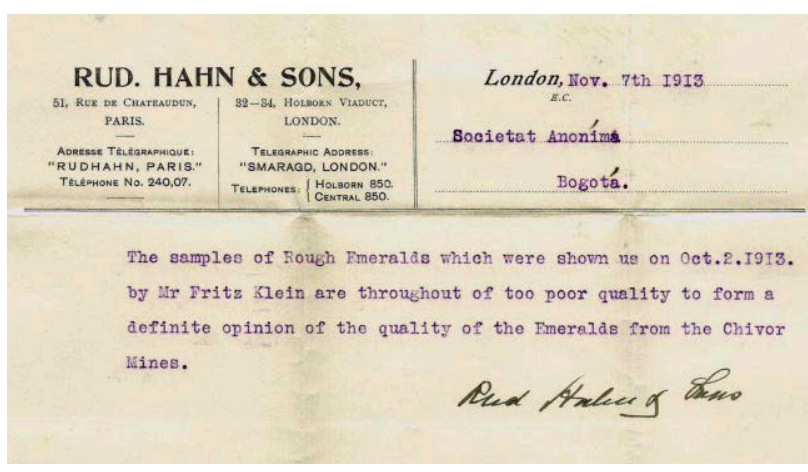

Figure 19. In a letter dated November 7, 1913, London-based Rudolf Hahn 4 ) Sons advised owners of the Chivor mines that the quality of the emerald samples shown by Fritz Klein was inadequate to justify purchase of the property. Courtesy of Eduardo Restrepo Ortega.

few days later, Klein and Scheibe embarked together in Hamburg, bound for Puerto Colombia. ${ }^{118}$

Following the just-described formalities, letters were sent from the Syndicate El Chivor to the German Ministry of Foreign Affairs in Berlin and to the German Resident in Bogotá. ${ }^{119}$ Therein, Schacht and Stauch sought to obtain clarification regarding the situation in Colombia, inquiring as to the legality of the mining titles, any obligations to pay taxes or additional fees, the parameters for authorized export of the emeralds and so forth. The German Resident in Bogotá, Dorotheus Kracker von Schwartzenfeldt, in turn contacted González as a representative of the mine owners, the attorney Cadavid, and the Ministro de Hacienda for details before responding in a letter to Schacht dated June $15,1914 .{ }^{120}$

${ }^{116}$ Letter from the Syndicate El Chivor, February 16, 1914, to Prof. Robert Scheibe, Historical Archive of the German Ministry of Foreign Affairs.

${ }^{117}$ Prof. Robert Scheibe (1859-1923) studied mathematics and natural sciences at the Martin Luther University of Halle-Wittenberg, Germany, where he received his $\mathrm{PhD}$ in 1882. In 1885, he became a member of the Royal Mining Academy (Königliche Bergakademie) in Berlin, where he was appointed professor in 1895. In the summer of 1908, Scheibe traveled to Namibia to study primary kimberlites. He met August Stauch, the discoverer of the secondary diamond deposits in the area of Lüderitzbucht. From late December 1908 to early January 1909, the two men made an excursion to the area south of Lüderitzbucht, where they found Pomona, potentially the richest diamond deposit ever discovered. Scheibe returned to Germany at the end of 1909, but he and Stauch remained friends for life. See Rauff, 1926; Strunz, 1970; Levinson, 2007.

${ }^{118}$ Files Robert Scheibe and Fritz Klein, Hamburger Passagierlisten, February 1914, Ancestry.de.

${ }^{119}$ Letters by the Syndicate El Chivor, March 14, 1914, and April 9, 1914, Historical Archive of the German Ministry of Foreign Affairs. ${ }^{120}$ Historical Archive of the German Ministry of Foreign Affairs. 


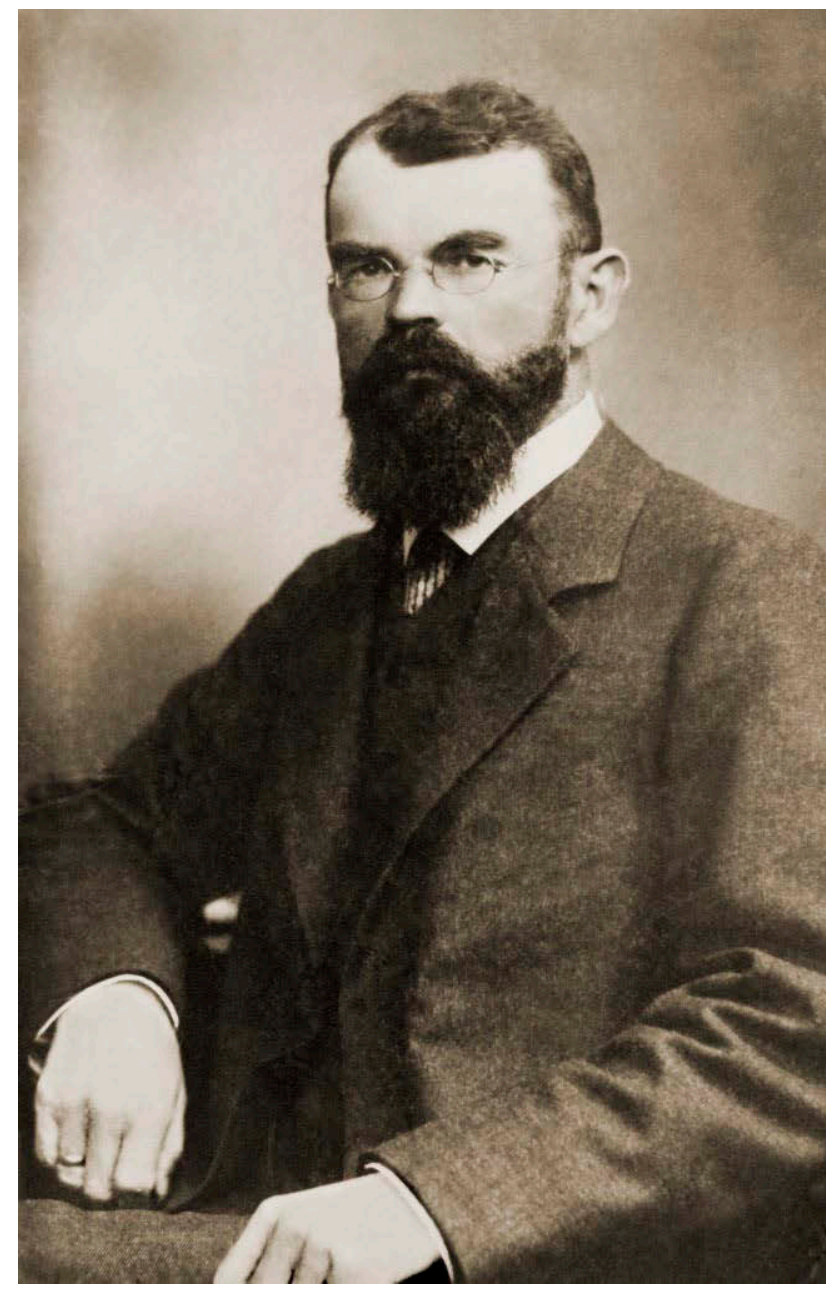

Figure 20. Prof. Robert Scheibe of the Royal Mining Academy (Königliche Bergakademie) in Berlin joined August Stauch in late 1908 to early 1909 in finding the major Pomona diamond deposit in Namibia. He was hired in 1914 by the Syndicate El Chivor to evaluate the Chivor mine. Photo circa 1910, Prof. Robert Scheibe collection, University Library Freiburg.

Scheibe arrived with Klein at Chivor on April 4, 1914. Over the course of the next several months, he prepared four interim communications ${ }^{121}$ and a final report, ${ }^{122}$ offering a window into circumstances at the mine during that time. At the outset of his visit, a period of heavy rain made geological fieldwork almost impossible. Progress was also impacted when, on April 20,1914, Restrepo became seriously ill and lost consciousness. As Scheibe wrote: ${ }^{123}$

We believed it a crisis in encephalitis but he did not wake up again, he lay motionless. On April 23rd we decided to transport him to Guateque despite the rain. The workers did as much as humanly as possible on the muddy and unstable mountain path. Mr. Klein and

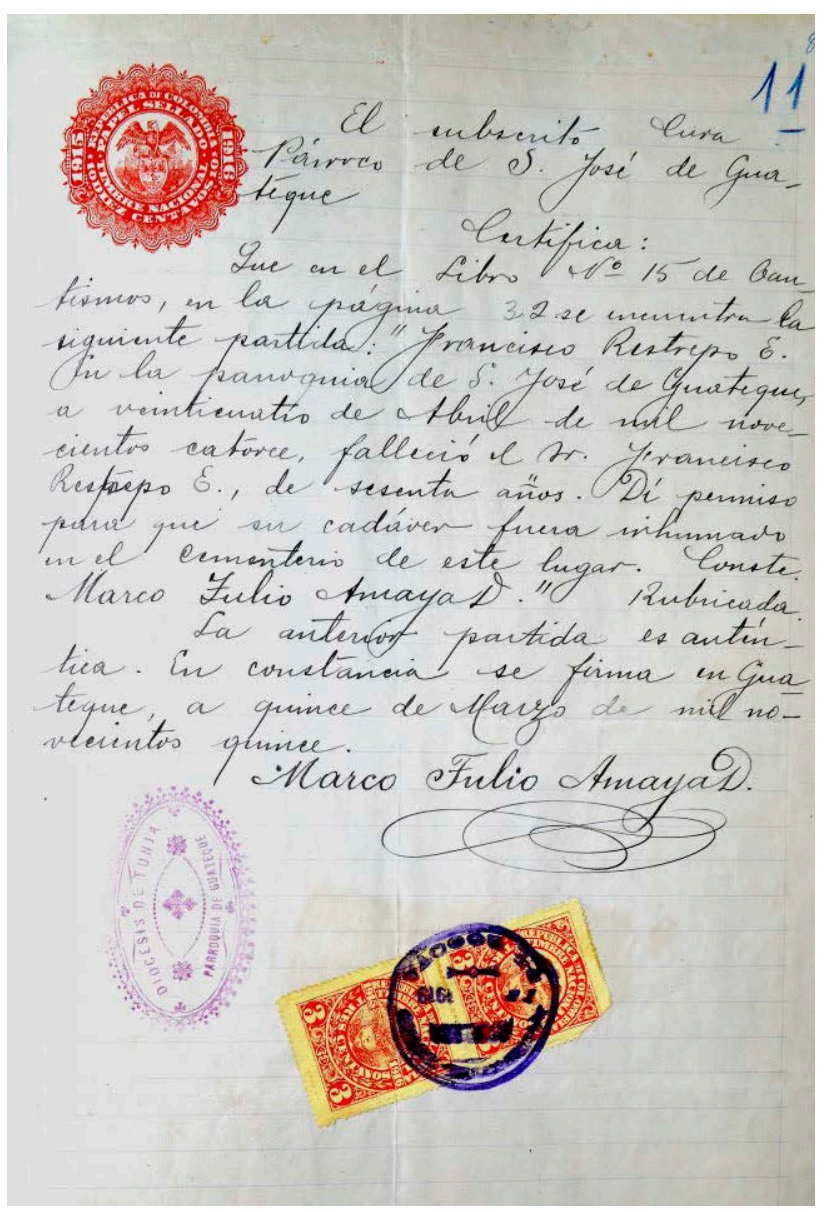

Figure 21. Restrepo's death certificate, dated April 24, 1914. File Inheritance F. Restrepo, Archivo General de la Nación (Colombia), Bogotá.

Mr. Restrepo's son, who was working as foreman here, accompanied the transport. On arrival at Guateque late in the evening, Mr. Restrepo died and was buried the day after.

A Colombian certificate of death dated April 24, 1914, was issued documenting Restrepo's passing (figure 21).

When conditions improved, three weeks were spent repairing the mine's aqueduct, after which the first clean but small emeralds were found in

\footnotetext{
${ }^{121}$ Letters by Prof. Robert Scheibe, Historical Archive of the German Ministry of Foreign Affairs.

${ }^{122}$ The final report, dated September 3, 1914, was provided by the grandchildren of Prof. Robert Scheibe.

${ }^{123}$ Letter from Prof. Robert Scheibe, May 1, 1914, Historical Archive
} of the German Ministry of Foreign Affairs. 
May and June and commercial material was mined in July. A representative of the German Residency in Bogotá also visited the mine from July 3 to 16, 1914, and reported on his observations. ${ }^{124}$ Between late July and early August, Scheibe finished his investigations, planning to return to Bogotá together with August Klein on August 2. ${ }^{125}$ The outbreak of war in early August, however, curtailed such plans and suspended Klein's pursuit of the Chivor project.

Scheibe's final report, ${ }^{126}$ dated September 3, 1914, and written in Bogotá, offered his conclusions as to the viability of Chivor. The report began with a detailed description of the geological conditions, then covered both the expected yield and the anticipated costs. As to the yield, he reported:

In the 4 months of my presence at the mine [April 4 to August 2, 1914] with a labor force of 25 men gem quality emeralds of a value of about 40,000 marks were mined.... I do not doubt that emeralds of a good kind are to be found elsewhere in the above mentioned area and beyond.... I consider the pit itself to be exploitable, especially since the prices of emeralds are high-also in Chivor stones were found that are estimated to 800 marks per carat. The average value of the usable stones found during my time there $(1,267$ ct $=39,420$ marks) is about 31 marks for one carat of raw stones.

The start-up investment for mining equipment was calculated at 150,000 marks. Annual operating costs for 150 workers, six supervisors, one commercial manager, one mining engineer, and one head of operational activities was estimated at 142,000 marks. Taking into account those parameters, in combination with the material recovered during his

\footnotetext{
${ }^{124}$ Report by a member of the German Residency in Bogotá, Josef Wipperfeld, July 20, 1914, Historical Archive of the German Ministry of Foreign Affairs.

${ }^{125}$ Letter from Fritz Klein, August 1, 1914, to the German Resident in Bogotá, German Federal Archive.

${ }^{126}$ Courtesy of Andreas Scheibe (grandson of Prof. Robert Scheibe).

${ }^{127}$ Diario Oficial (Colombia), 50, No. 15355 (1914), pp. 1127-1128.

${ }^{128}$ Klein, 1941, 1951.

${ }^{129}$ Military files of the 20th lancer regiment, Ludwigsburg, Germany, Hauptstaatsarchiv Stuttgart.

${ }^{130}$ Klein, 1941, 1951.

131 "Inventory of the tools of the Chivor mine which are held by Anatolio Morales in El Rosal," January 5, 1916, 2 pp.

${ }^{132}$ The scientific studies on Muzo by Prof. Robert Scheibe were published initially in Spanish and later edited by his son, Dr. Ernst Albrecht Scheibe, in German. See Scheibe, 1916, 1922, 1926. The younger Scheibe, like his father, traveled to Colombia and worked as a geologist from 1924 to 1929 .

${ }^{133}$ Rauff, 1926; Strunz, 1970.
}

time there and the purchase price for the mine, Scheibe saw a realistic chance for a successful venture but also an extremely high "risk" in buying the mine under the existing conditions. Hence, he was unable to offer an unqualified recommendation to buy Chivor for the contract price.

\section{WORLD WAR I}

The international conflict that became World War I began in August 1914 and had far-reaching consequences for Chivor. Germans who found themselves overseas faced an ongoing series of complications and decisions. Early on, there was hope that hostilities would end quickly and normal business pursuits could be resumed after waiting a few months. As that hope faded, the desire to return home became stronger. However, a simple trip to Germany was hindered by the fact that British warships stopped commercial or passenger ships, even vessels of neutral states, and transported any German passengers to internment camps.

Klein waited, using the time to reprise his efforts to obtain permission for an emerald-cutting enterprise in Colombia. As before, his petition dated November 12, 1914, was swiftly rejected. ${ }^{127}$ Klein then left Colombia in December 1914 or January 1915, returning to Germany, possibly under false papers. ${ }^{128}$ He entered a cavalry regiment stationed in Ludwigsburg, southern Germany, as a volunteer on February 20, 1915. ${ }^{129}$ According to Klein, he felt that this service was a duty he owed to his country. ${ }^{130}$ The equipment used at Chivor was held by a custodian in Klein's absence, presumably in hopes of resuming operations in the future. ${ }^{131}$

Scheibe deemed an attempt to return to Germany, combined possibly with years of internment, too risky. He therefore decided to stay in Colombia, working for the government as a geologist. Becoming head of the Comisión Científica Nacional (National Geological Commission), he devoted himself to exploring the country's important mineral resources. For instance, he prepared reports on the Muzo emerald deposit, published in 1916 and 1922, for the Ministro de Hacienda. ${ }^{132}$ His work on behalf of the government continued until his return to Germany in the spring of $1920^{133}$ and was recognized with appointment as an honorary professor at the University of Bogotá. Upon request of the government, Scheibe subsequently returned to Colombia in 1921 under a three-year contract, again as the head of the Comisión Científica Nacional. 


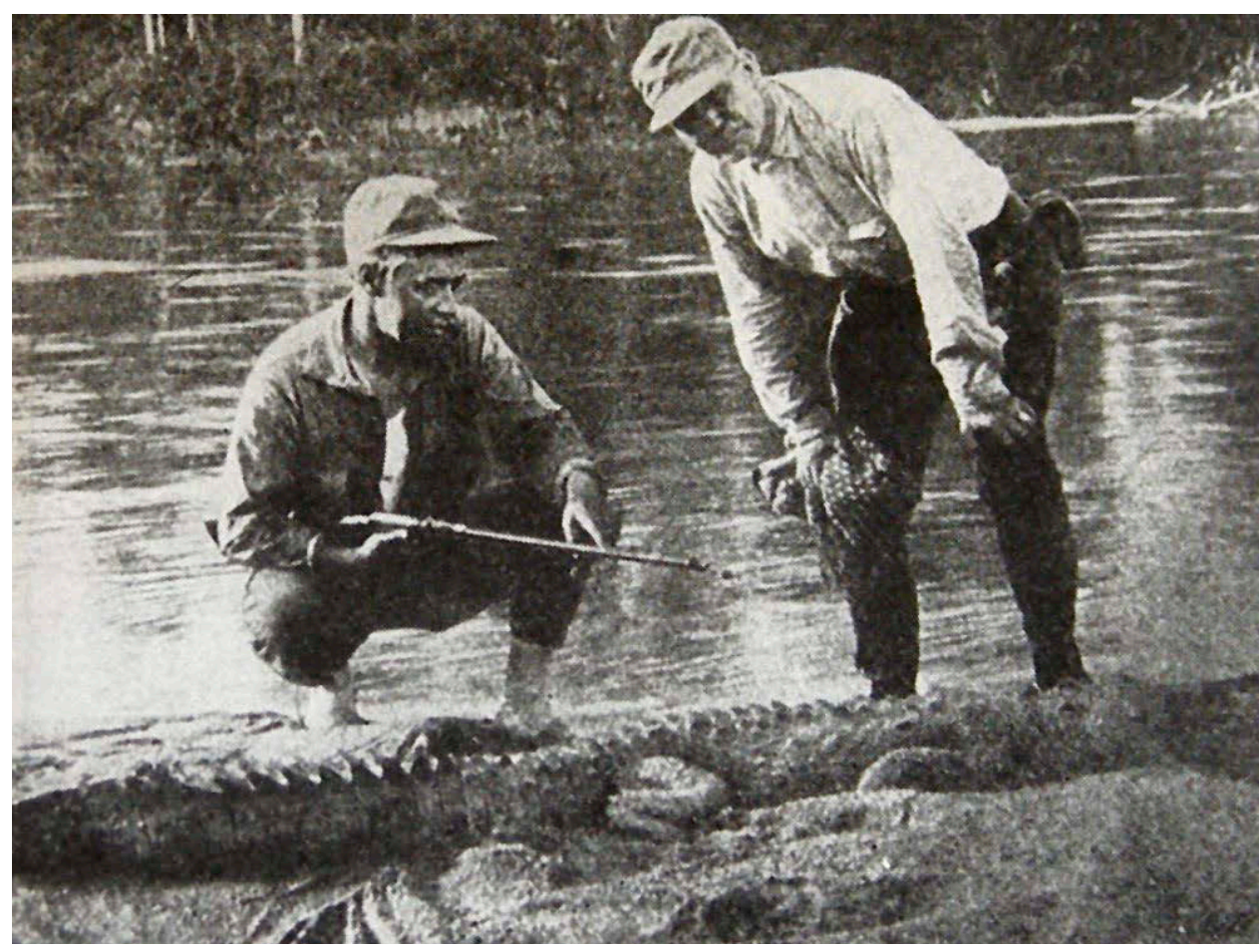

Figure 22. In 1917, a group of American and Colombian businessmen and geologists associated with the Carib Syndicate, Ltd., investigated oil fields located at the border between Colombia and Venezuela. Carl K. MacFadden (left) and Wilson E. Griffiths participated in the excursion, which resulted in the 1918 transfer of property referred to as the "Barco concession" to an American oil company. Photo 1917 , public domain.

\section{PURCHASE OF CHIVOR BY AN AMERICAN COMPANY (1919)}

Following World War I, both Klein and his brother August were interested in continuing with the Chivor project. Nonetheless, several developments during the interim changed their previous plans and expectations. From a personal standpoint, each of the Klein brothers had married in 1919, Fritz to Claire Cullmann and August to Liese Brill, so future work would need to take their new wives into consideration.

From a business perspective, war altered the economic landscape for the Syndicate El Chivor. The exchange rate of the mark decreased dramatically, and the financial situation for at least one investor, Rudolf Hahn \& Sons, London, deteriorated substantially. ${ }^{134}$ To accommodate this scenario, a new investor in the Syndicate El Chivor was found, the Dutch shipping firm Wm H. Müller \& Co., based in The Hague and Rotterdam. ${ }^{135}$ In addition to its primary shipping and transport business, $\mathrm{Wm} \mathrm{H}$. Müller \& Co. participated in various mines and other industrial companies.

After the foregoing preparations were initiated, Klein and his wife Claire left Germany for Bogotá in late July or early August 1919.136

Meanwhile, a new competitor for Chivor had entered the fray after Klein's option expired during the war. The Colombian Emerald Syndicate, Ltd. had been founded in the United States on June 22, $1918,{ }^{137}$ by a group of American bankers and speculators from the oil industry. Those involved were principally associated with the Carib Syndicate, Ltd. and the Colombian Petroleum Co., which pursued commercial ventures in the oil business in Colombia and Venezuela. ${ }^{138}$ Key figures included Wilson E. Griffiths (1851-1929) and Carl K. MacFadden (1872-1952). ${ }^{139}$ Griffiths and MacFadden (figure 22) made several trips to Colombia between 1917

\footnotetext{
${ }^{134}$ Eugen and Paul Hahn, as well as their brother Rudolf, had been interned in the United Kingdom from 1915 to 1918. Assets of the company in the United States worth $\$ 225,000$ and in Britain worth $£ 250,000$ (equivalent to US $\$ 1,250,000$ ) had been confiscated as enemy property. See Hahn v. Public Trustee, [1925] Ch. 715 (Eng.); [1926] 95 Law Journal Reports 9 (Ch.), pp. 9-22 (Eng.).

${ }^{135}$ Letter from August and Liese Klein, January 4, 1920, to Fritz and Claire Klein. No further relevant documentation was found in archived records of Wm H. Müller \& Co., held at the Rotterdam City Archive (Stadsarchief Rotterdam).

${ }^{136}$ Letter from August and Liese Klein, September 26, 1919, to Fritz and Claire Klein.

${ }^{137} \mathrm{https}: / /$ opencorporates.com/companies/us_de/74916.

${ }^{138}$ The Wall Street Journal, May 26, 1919, p. 8; The Honolulu Advertiser, December 7, 1919, p. 29; The Wall Street Journal, May 21 1920, p. 8; Encyclopedia of American Biography, New Series, 9 (1938), pp. 401-402.

${ }^{139}$ The Pittsburgh Press, December 29, 1895, p. 12; Escritura 3084, December 27, 1919, Notaria 1, Archivo General de la Nación (Colombia); Rausch, 2014; Torres del Río, 2015. MacFadden's name is also written as Mac Fadden or McFadden.
} 


\section{Carib Syndicate Limited}

\section{Colombian Emerald Syndicate Ltd.}

\author{
Carib Trading Co. \\ (Compañia Comercial del Caribe)

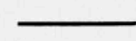 \\ Oficinas en \\ Bogotá-Cartagena \\ Colombia, S. A. \\ Oficinas en New York \\ 90 West Street \\ New York City \\ 301.
}

Figure 23. Although the American companies involved in Colombian oil and emerald were formally separate, they were led by the same individuals and were even marketed in joint advertisements. Image from "The Colombian Review," published by the Government Information Bureau of the Republic of Colombia, New York, 1920.

and 1920, focused generally on establishing American interests in the oil business there and particularly on obtaining control of an oil field at the border between Colombia and Venezuela, referred to as the "Barco concession." The emerald business was merely an adjunct to their activities in the oil industry. The companies operating in the two sectors were formally separate but were led by the same officials and were even marketed jointly in advertisements (figure 23).

An option contract to purchase Chivor had already been obtained on April 3, 1918, ${ }^{140}$ prior to establishing the Colombian Emerald Syndicate in June 1918. ${ }^{141}$ A second option contract was executed on August 13, 1919, ${ }^{142}$ with a term running to December 8, 1919. ${ }^{143}$ MacFadden's attention had been drawn to the Chivor emerald mine and its history by Dixon. ${ }^{144}$

Upon his arrival at the Colombian port of Barranquilla, Klein was informed of a legally valid option contract held by the U.S.-based corporation. ${ }^{145}$ Hence, Klein could only wait to see if the Americans exercised the option, as expressed by his brother: "Now, December 8 is getting close, and thus the final decision. We are of course all very excited about the result and would be very happy if it turns out in your favor." ${ }^{\prime 146}$

In a last-ditch effort to thwart the signing of a deal by the Americans, Klein on December 22, 1919, filed a complaint with the Colombian government alleging that the legal status of Chivor 1 and 2 was unclear. ${ }^{147}$ Such a move, which would likely have rendered the property unavailable for sale pending any attendant investigation, resulted only in directives that Klein support his assertions with documentary evidence. ${ }^{148}$ When he failed to do so, the complaint was dismissed in April 1921, having had no effect. ${ }^{149}$

On December 27, 1919, Chivor 1 and 2 were purchased from the Sociedad Ordinaria de las Minas de

${ }^{140}$ This first option was mentioned in the sales contract for Chivor, Escritura 3084, December 27, 1919, Notaria 1, Archivo General de la Nación (Colombia).

${ }^{141}$ These two events coincided with the travels of Griffiths and MacFadden, who were together in Colombia in early 1918 before leaving the country on April 20 and arriving in New York on May 3, 1918. Files Wilson E. Griffiths and Carl K. MacFadden, List of United States Citizens, Arriving at Port of New York, May 3, 1918, Ancestry.com. The option was thus signed while they were in Colombia, and the company was incorporated shortly after their return to the United States. Although the actual April 3, 1918, option contract for Chivor has not been found, an option contract with that date and signed by Griffiths was located for the transfer of an oil field concession from Virgilio Barco to the Compañía Colombiana de Petróleo. Escritura 331, April 3, 1918, Notaria 4, Archivo General de la Nación (Colombia).

${ }^{142}$ This second option was also mentioned in the sales contract for Chivor, Escritura 3084, December 27, 1919, Notaria 1, Archivo General de la Nación (Colombia).

${ }^{143}$ Letter from August and Liese Klein, December 5, 1919, to Fritz and Claire Klein; Canova, 1921.

${ }^{144}$ Rainier, 1931, p. 223 (comment by Carl K. MacFadden).

${ }^{145}$ Letter from August and Liese Klein, September 26, 1919, to Fritz and Claire Klein.

${ }^{146}$ Letter by August and Liese Klein, December 5, 1919, to Fritz and Claire Klein. The more dramatic situation suggested by Klein (1941, 1951) and by Canova (1921) appears to have been exaggerated. The Historical Archive of the German Ministry of Foreign Affairs contains only a brief note, dated December 29, 1919, concerning the sale of Chivor to an American company.

${ }^{147}$ Diario Oficial (Colombia), 56, No. 17080-17081 (1920), p. 273.

${ }^{148}$ Diario Oficial (Colombia), 56, No. 17102-17103 (1920), pp. 361362.

${ }^{149}$ Diario Oficial (Colombia), 57, No. 17687-17688 (1921), p. 258. 


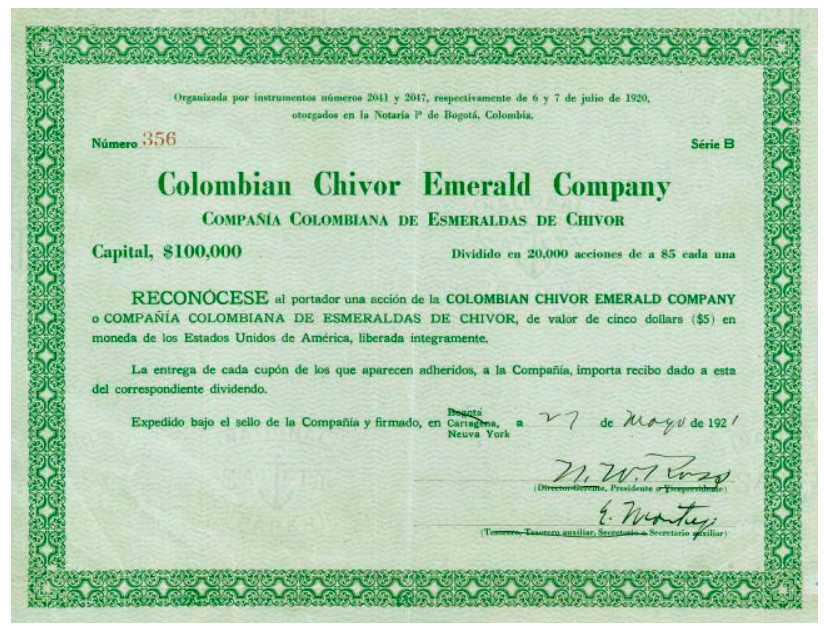

Figure 24. Share certificate for the Colombian Chivor Emerald Company (Compañía Colombiana de Esmeraldas de Chivor), formed in 1920 in Colombia as the operating company for the U.S.-based Colombian Emerald Syndicate, Ltd., which had purchased the Chivor mines in December 1919. Courtesy of Eduardo Restrepo Ortega.

Chivor by the American group. ${ }^{150}$ Pursuant to the sale contract, the mine titles for Chivor 1 and 2 and the land holdings of the Colombian company were transferred for a purchase price of $£ 46,000$ (equivalent to US $\$ 230,000)$ to Griffiths and MacFadden. Griffiths and MacFadden were represented in the transaction by Leon J. Canova, acting under a power of attorney dated October 31, 1919. ${ }^{151}$

In retrospect, circumstances rendered it almost a foregone conclusion that the Colombian Emerald Syndicate would not turn away from the opportunity to purchase Chivor. Between the corporation's founding and the time the option was exercised, the price of the 4,000 issued shares had increased from $\$ 25$ to approximately $\$ 1,100,{ }^{152}$ with continued appreciation to $\$ 4,000$ or $\$ 5,000$ expected. ${ }^{153}$ Moreover, the company had already started mining operations, and president Nathaniel W. Ross (1874-1938) was by October 1919 referring to Chivor as "the company's mine." 154 Civil mining engineer Harold Case Willcox had been hired in December 1919 to map the area for a deeper understanding of the geological setting, and he continued in that position until March 1920. ${ }^{155}$ Later, Willcox worked for the Carib Syndicate, Ltd., in Colombia, underscoring the interconnectedness of the companies involved with the American investors. ${ }^{156}$
In July 1920, a local mining company was formed in Colombia by Griffiths and MacFadden to serve as the operating entity for the Colombian Emerald Syndicate. ${ }^{157}$ Known as Colombian Chivor Emerald Company (Compañía Colombiana de Esmeraldas de Chivor), stated capital was to consist of 20,000 shares at $\$ 5$ each (figure 24 ; again, see table 2).

In September 1920, Ross retired from business and was thereafter succeeded by MacFadden as president of the Colombian Emerald Syndicate. ${ }^{158}$ Griffiths served as one of the company's directors, and Dixon acted as the Colombian manager. ${ }^{159}$

By 1921, interests in the titles to the other three Chivor mines, Triunfo de Chivor, Paz de Chivor, and Esperanza de Chivor were represented to be under the ownership or control of the Colombian Emerald Syndicate or the Colombian Chivor Emerald Company, ${ }_{1}^{160}$ but the nature of any relevant transactions is not otherwise elucidated (again, see box A).

\section{KLEIN'S ACTIVITIES FOR THE COLOMBIAN EMERALD SYNDICATE, LTD. (1920-1921 AND 1922-1923)}

After the sale of Chivor to the American corporation at the end of 1919, Klein and his wife remained in Colombia. Although the idea of opening a jewelry shop in Bogotá was apparently broached by the Klein

\footnotetext{
${ }^{150}$ Escritura 3084, December 27, 1919, Notaria 1, Archivo General de la Nación (Colombia).

${ }^{151} \mathrm{l}$ bid.

${ }^{152} \mathrm{~A}$ share split was performed in late October to early November 1919, with the value of 50 new shares being equivalent to that of one old share. The Washington Post, December 11, 1919, p. 11.

${ }^{153}$ The Buffalo Enquirer, May 27, 1919, p. 8; New York Tribune, October 26, 1919, p. 26; Quad-City Times, October 27, 1919, p. 12; Springfield Missouri Republican, November 7, 1919, p. 6; The Salt Lake Tribune, December 3, 1919, p. 18; The Washington Post, December 11, 1919, p.11.

${ }^{154}$ The Wall Street Journal, October 29, 1919, p. 15.

${ }^{155}$ Schwarz, 1953.

${ }^{156}$ American Society of Civil Engineers, Year Book 1920, p. 312; Oildom, 12 (1921), pp. 28-30.

${ }^{157}$ Escritura 2041, July 6, 1920, Notaria 1, and Escritura 2047, July 7, 1920, Notaria 1, Archivo General de la Nación (Colombia). Diario Oficial (Colombia) 56, No. 17238-17239 (1920), pp. 99-100.

${ }^{158}$ MacFadden, 1920; National Petroleum News, 12, December 1, 1920, pp. 75-76; Pittsburgh Daily Post, April 27, 1921, p. 11; Canova, 1921; Moore and Wilson, 2016. MacFadden had also become president of the Carib Syndicate, Ltd., in September 1920. The New York Times, September 10, 1920, p. 24.

${ }^{159}$ Moody's Manual of Investments: American and Foreign, 11, Part 2 (1920), p. 1189; Moody's Manual of Investments: American and Foreign, 12, Part 2 (1921), p. 697; Canova, 1921.

${ }^{160}$ Canova, 1921.
} 


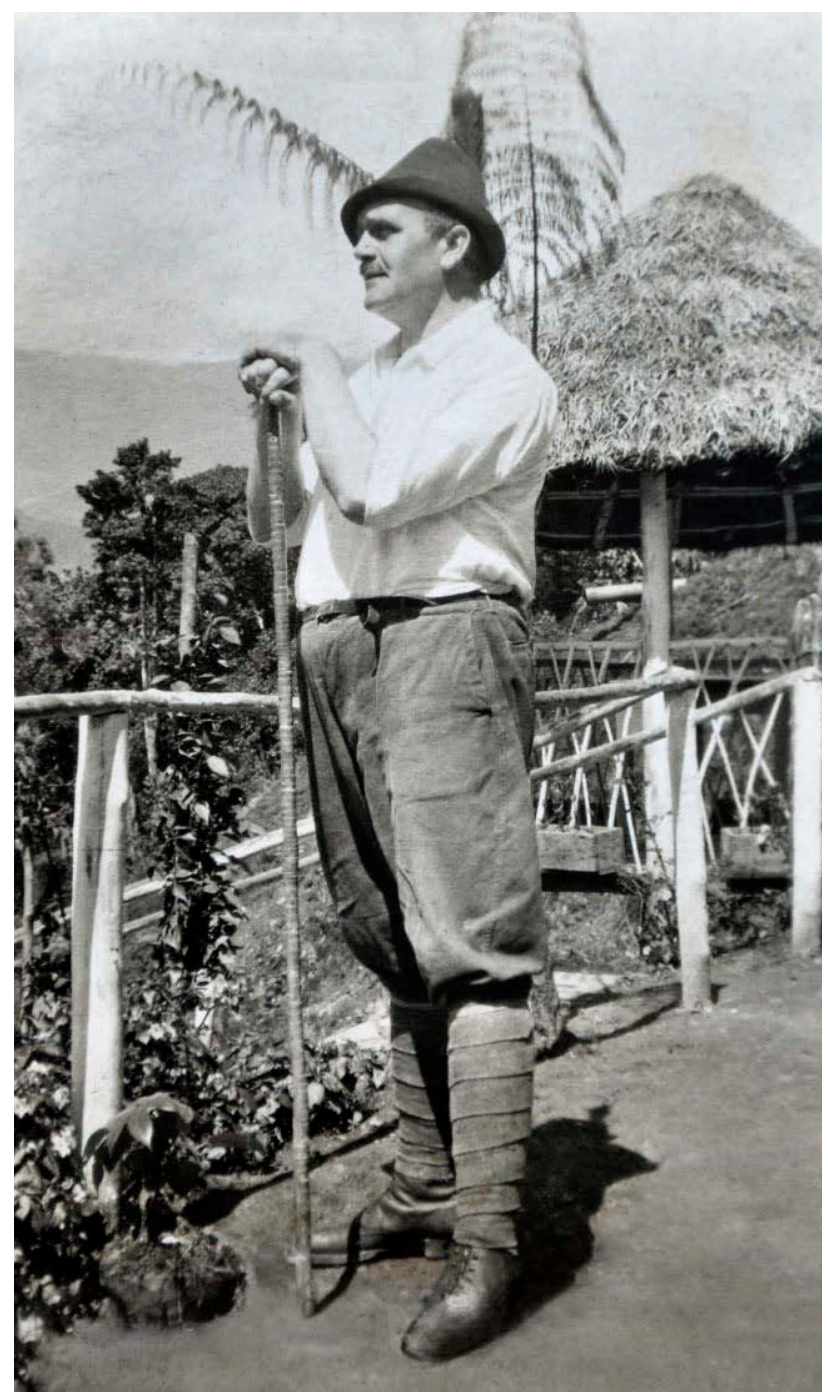

Figure 25. Fritz Klein was unable to purchase the Chivor mining titles in 1919 on account of intervening developments during World War I. The U.S.-based Colombian Emerald Syndicate, Ltd., obtained option contracts in the interim and subsequently completed the acquisition. Klein remained in Colombia and was hired in the fall of 1920 by the new mine owners to lead operations at Chivor. Photo circa 1920 to 1921, courtesy of Carola Kroll.

brothers, such a plan was never implemented. Instead, Klein (figure 25) was hired by the Colombian Emerald Syndicate for two terms as head of mining operations at Chivor, from 1920 to 1921 and 1922 to $1923 .{ }^{161}$

At the time of Klein's hiring, Dixon had been overseeing Chivor's administration. ${ }^{162}$ According to Klein (1941, 1951), he was hired because Dixon had failed to obtain a profitable supply of gem-quality emeralds. However, during Klein's first engagement, Dixon continued to be involved in the background, still working for the Colombian Emerald Syndicate.

At that time, the mine was worked exclusively by the traditional open-cut method of preparing terraces or steps in the extremely steep environment (figure 26). During the initial contract period of approximately six months from the fall of 1920 to the spring of 1921, Klein was assisted by several American mining engineers, including Eugene Brossard. ${ }^{163}$ A notable discovery occurred in December 1920 when a 632 ct emerald crystal (figure 27) was found at Chivor by miner Justo Daza. ${ }^{164}$ Klein $(1941,1951)$ recounted that Daza located the cavity and that Klein himself carefully removed the crystal. The emerald was personally transported to New York by Brossard in January 1921. ${ }^{165}$ The extraordinary stone generated great interest in the United States, and its arrival in New York was widely reported in the nation's press. ${ }^{166}$

The crystal was subsequently named the "Patrizius" or "Patricia" emerald after the patron saint of Ireland, the green island, according to Klein. ${ }^{167}$ Speculation that it might have been named after Klein's

\footnotetext{
${ }^{161}$ Klein, 1941, 1951. No known contracts have been preserved to offer specific details, but general parameters and time frames can also be drawn from other contemporaneous materials such as newspaper reports and travel documents.

${ }^{162}$ An example of Christopher Dixon's leadership can be found in the form of a certificate he signed on September 27, 1920, at the time of Anibal Restrepo's departure from employment at Chivor and recognizing nine months of exemplary service for the Colombian Emerald Syndicate, Ltd.

${ }^{163}$ Eugene Brossard's work in Colombia was recognized in an alumni publication of his alma mater: "Eugene Brossard Madison, is in the employ of the Colombian Emerald Syndicate... as assistant to the superintendent of the Chivor emerald mines." The Wisconsin Alumni Magazine, 21, No. 6 (1920), p. 171. Another assistant at Chivor was F. Stewart Turneaure. Wisconsin State Journal, September 4, 1921, p. 7; Proceedings of the Geological Society of America for 1945, published 1946, p. 106. Yet another American involved at Chivor was the mining engineer William Burns, who was first employed by the Colombian Emerald Syndicate, Ltd., returning to New York in May 1922, and who later worked for the Colombia Emerald Development Corporation at Chivor in 1925. File William Burns, List of United States Citizens, Arriving at Port of New York, May 14, 1922, MyHeritage.com; Brock (1929).

${ }^{164}$ Canova, 1921; Klein 1941, 1951; Johnson, 1959, 1961; Weldon et al., 2016 .

${ }^{165}$ File Eugene Brossard, List of United States Citizens, Arriving at Port of New York, January 14, 1921, MyHeritage.com.

${ }^{166}$ The Brooklyn Daily Eagle, February 2, 1921, p. 1; The Montana Standard, February 7, 1921, p. 3; Sikeston Standard, February 8, 1921, p. 3; The Tennessean, February 15, 1921, p. 9. Inconsistently, multiple articles or reports in American newspapers from February or March 1921 provided a weight of $630 \mathrm{ct}$.

${ }^{167}$ Klein, 1941.
} 

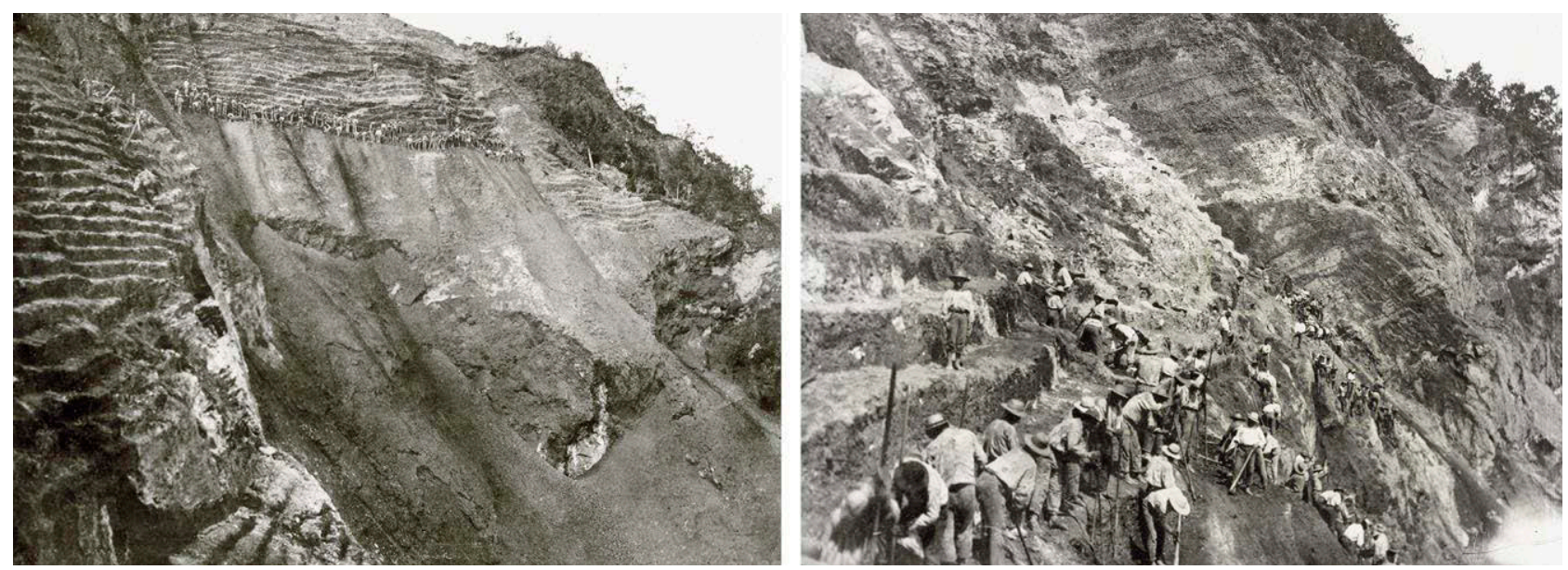

Figure 26. Mining at Chivor in the 1920s was performed exclusively by the open-cut method, preparing terraces or narrow steps in the extremely steep environment. Indigenous miners worked with long iron bars and hoes to remove the overburden and locate emerald-bearing veins or cavities. Photos of open-cast mining at Banco Klein, circa 1920 to 1921, courtesy of Carola Kroll.

daughter ${ }^{168}$ (whose name was Susanne) ${ }^{169}$ is unfounded. Whether to cut the stone was initially debated, but the crystal was preserved as such. ${ }^{170}$ The

Figure 27. Left: In 1920, while Fritz Klein was leading mining operations at Chivor, an extraordinarily large emerald crystal weighing $632 \mathrm{ct}$ was discovered in the open-cast mine. The crystal was transported to New York by mining engineer Eugene Brossard and widely reported in the American press. The emerald was donated to the American Museum of Natural History, $\mathrm{New}$ York, in 1953. Courtesy of the American Museum of Natural History. Right: Klein (1941) also depicted the crystal, named the "Patricia" emerald.
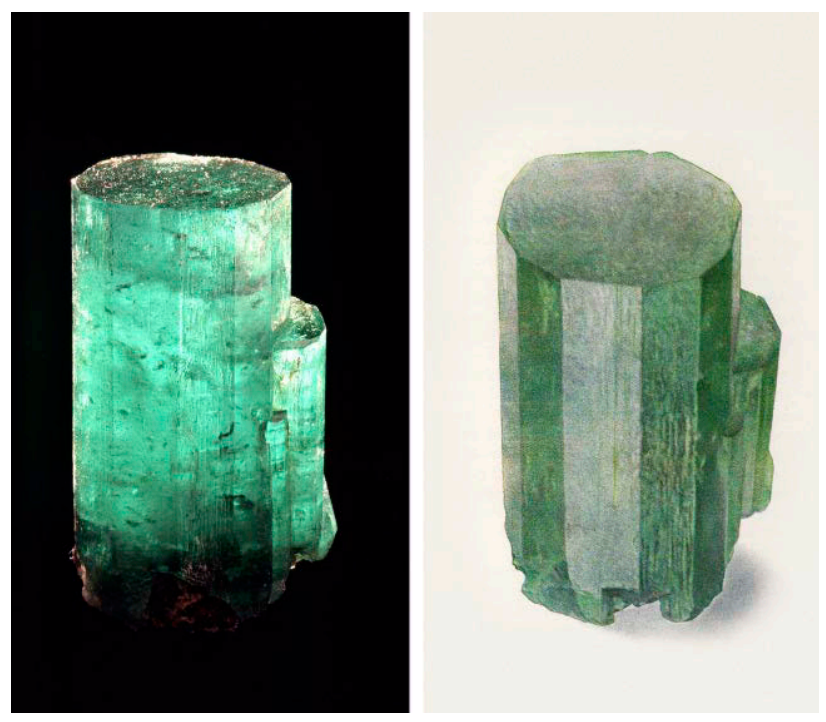

632 ct emerald crystal is now in the collection of the American Museum of Natural History, New York, inventory number 42027, and was donated to the museum in 1953 by Mr. and Mrs. J. Robert Rubin. ${ }^{171}$ Rubin (1882-1958), a New York lawyer, served as one of the trustees and/or directors of the Colombian Emerald Syndicate in the 1920s. ${ }^{172}$ Prior to its donation, the emerald was transferred internally among company officials after financial pressures in March 1923 led the company to borrow $\$ 3,000$ from two of the directors, pledging the emerald as security. ${ }^{173}$

After Klein's first contractual commitment with the Colombian Emerald Syndicate ended, he and his wife returned to Germany via New York. They arrived at the New York port in August 1921 and may have spent a period of several months before continuing their journey. ${ }^{174}$

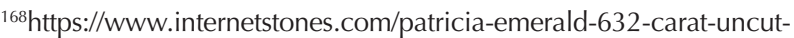
colombian-origin-chivor-mine.html.

${ }^{169}$ Carola Kroll (granddaughter of Fritz Klein), pers. comm., 2017.

${ }^{170}$ Jewelers' Circular, 82, No. 6 (1921), p. 79.

${ }^{171}$ Press release, November 9, 1953, American Museum of Natural History, New York; Jamie Newman, American Museum of Natural History, New York, pers. comm., 2016.

${ }^{172}$ Encyclopedia of American Biography, New Series, 9 (1938), pp. 401-402.

173/ewelers' Circular, 86, No. 10 (1923), p. 83.

${ }^{174}$ The documentation cites the Colombian Emerald Syndicate, Ltd., as Fritz Klein's employer and gives four months as the intended length of stay in the United States. File Fritz Klein, List or Manifest of Alien Passengers for the United States Immigration Officer at Port of Arrival, New York, August 1921, MyHeritage.com.
} 


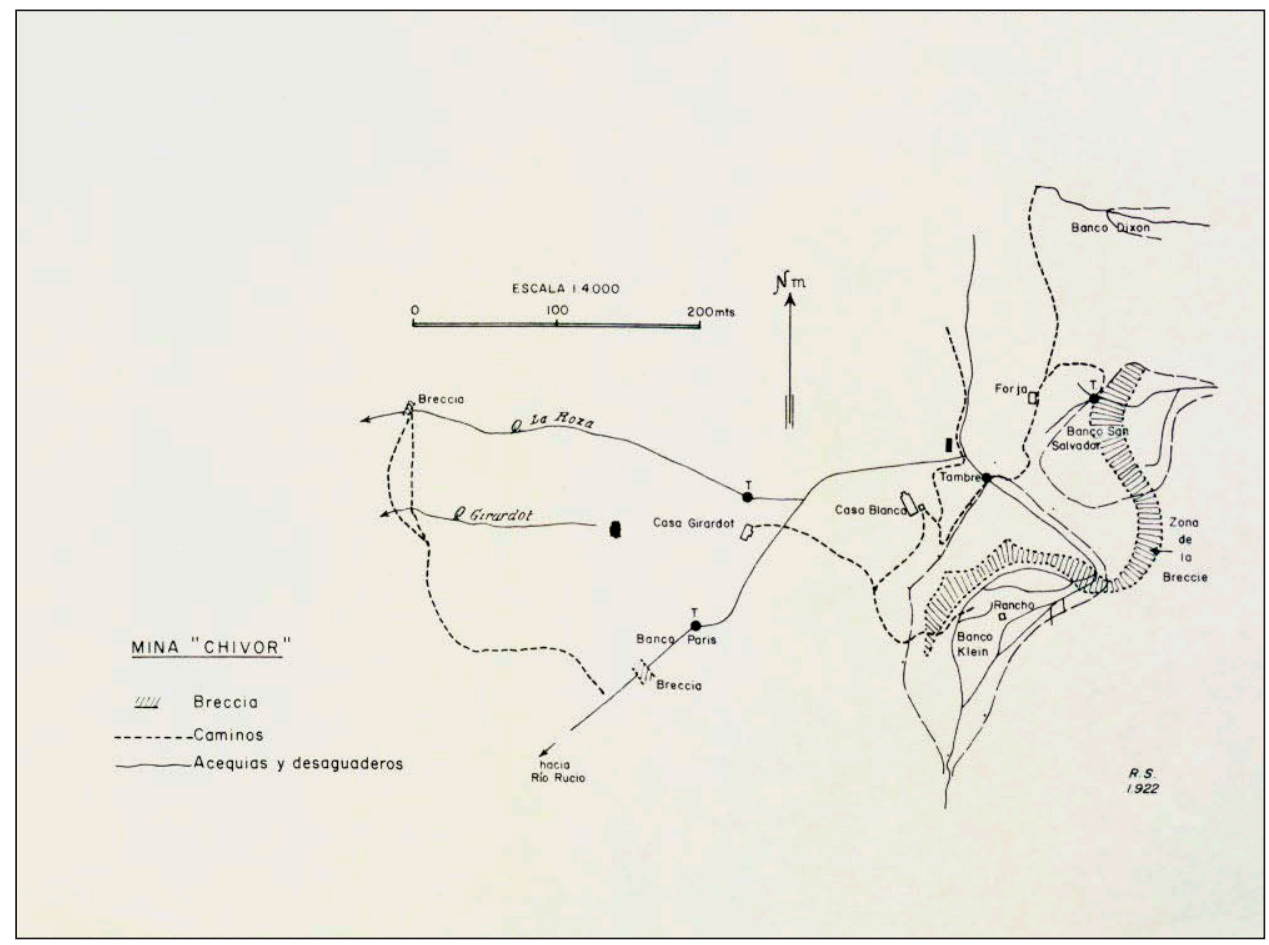

Figure 28. Hand-drawn map showing the topography of the Chivor mine and related geological details, signed R.S. [Robert Scheibe] 1922. The drawing also identified the locations principally worked by Fritz Klein and Christopher Dixon, labeled "Banco Klein" and "Banco Dixon," respectively. Prof. Robert Scheibe collection, University Library Freiburg.

Following Klein's initial engagement at the helm in Chivor, Dixon resumed leadership of mining operations. ${ }^{175}$ Dixon reportedly claimed that during the six months from June to December 1921, emeralds worth $\$ 176,000$ were recovered under his management. ${ }^{176}$ Meanwhile, the corporate leadership in New York had undergone a transition. MacFadden resigned in September 1921 from his role at the head of the Colombian Emerald Syndicate and was succeeded by Julian A. Arroyo. ${ }^{177}$ In summer of 1922, the company's vice president, Joseph J. Paris, visited Colombia, returning to New York on June 15. ${ }^{178}$ About one week later, Dixon arrived in New York, ${ }^{179}$ and he spent time in the city during June and July, ${ }^{180}$ presumably meeting with Colombian Emerald Syndicate officials to discuss further activities at Chivor. Because no documentation after 1922 mentions Dixon in a management role at Chivor, the implication is that no agreement for his continued employment was reached. ${ }^{181}$ That, in turn, might have led to the rehiring of Klein.

The precise dates of Klein's second contractual commitment with the Colombian Emerald Syndicate are unknown. He first traveled alone to Colombia, and his wife followed in August 1922. ${ }^{182}$ Good production was reported during this time, ${ }^{183}$ and Scheibe returned to conduct further scientific study at Chivor (figure 28). ${ }^{184}$ Nevertheless, the financial support for work at the mine was reduced, and, ultimately, mining activities were terminated. Even now, the reasons that precipitated the decline remain shrouded in history. On the corporate side, Paris replaced Arroyo as president in October 1922. ${ }^{185}$ Min-

${ }^{175}$ Moody's Manual of Investments: American and Foreign, 11, Part 2 (1920), p. 1189; Moody's Manual of Investments: American and Foreign, 12, Part 2 (1921), p. 697; Canova, 1921.

${ }^{176}$ Gilles, 1930.

${ }^{177}$ New York Tribune, September 13, 1921, p. 6; Engineering and Mining Journal 112 (1921), p. 466; The New York Herald, September 13, 1921; The New York Times, September 13, 1921. Some months later Carl K. MacFadden was also dismissed from his role at the Carib Syndicate, Ltd., oil company. New York Times, April 18, 1922, p. 32.

${ }^{178}$ File Joseph Paris, List or Manifest of Alien Passengers for the United States Immigration Officer at Port of Arrival, New York, June 1922, MyHeritage.com; Investor \& Trader, July 1, 1922, p. 6.

${ }^{179}$ File Christopher Dixon, List or Manifest of Alien Passengers for the United States Immigration Officer at Port of Arrival, New York, June 1922, MyHeritage.com.

${ }^{180}$ The Washington Times, July 2, 1922, p. 3.

${ }^{181}$ Moody's Manual of Investments: American and Foreign, 13, Part 2 (1922), p. 874; Investor \& Trader, June 24, 1922, p. 6.

${ }^{182} \mathrm{Claire}$ Klein traveled alone from Hamburg to Puerto Colombia. File Claire Klein, Hamburger Passagierlisten, August 1922, Ancestry.de.

${ }^{183}$ Investor \& Trader, August 19, 1922, p. 2, September 9, 1922, p. 2, and September 30, 1922, p. 12; Klein, 1941, 1951.

${ }^{184}$ Prof. Robert Scheibe fell ill in Colombia in February 1923 and died on March 3, following appendicitis and peritonitis. As a result, the Chivor study was never completed. A decree by the Colombian President dated March 8, 1923, was issued in honor of the deceased, and numerous Colombian newspapers carried his obituary. The congress in Bogotá honored his work and his selfless service to Colombia in June 1923 with an official state ceremony. Historical Archive of the German Ministry of Foreign Affairs. Diario Oficial (Colombia) 59, No. 18841-18842 (1923), p. 629.

185Investor \& Trader, October 14, 1922, p. 8. 
ing engineer Brossard, with whom Klein had worked at Chivor, returned to the United States in July $1923 .{ }^{186}$

\section{BANKRUPTCY OF THE COLOMBIAN EMERALD SYNDICATE, LTD. (1923)}

As noted above, financial pressures at the company had become severe by March 1923 on account of expenses that exceeded the income generated from emerald sales. By April 4, 1923, an involuntary petition in bankruptcy had been filed against the Colombian Emerald Syndicate in the United States District Court in New York. ${ }^{187}$ At that time, Paris was still serving as the president, and Wolcott H. Pitkin was appointed receiver for purposes of the bankruptcy proceeding. ${ }^{188}$ Liabilities were initially estimated at between $\$ 45,000$ and $\$ 48,000 .{ }^{189}$ Schedules detailing the assets of $\$ 314,039$ and liabilities of $\$ 37,816$ were then filed with the court on December 17, 1923. ${ }^{190}$

At that time, the Colombian Emerald Syndicate owned the Chivor 1 and 2 mine titles and a one-third interest in the titles to the three other mines of the Chivor group. ${ }^{191}$ Outstanding debts were owed to, among others, present or former presidents, vice presidents, and/or directors of the corporation, such as MacFadden, Griffiths, Arroyo, and Rubin. Other listed creditors included Klein, mining engineer Brossard, the corporation's attorney in Colombia Miguel S. Uribe Holguin, the Carib Syndicate, and the German firm Hahn \& Klein. ${ }^{192}$

Meanwhile, a stockholders' committee was established to devise a method of raising funds to pay off the liabilities, and it was proposed that a new company would be formed to bid for the assets in an anticipated bankruptcy auction. ${ }^{193} \mathrm{~A}$ special meeting of creditors was held in January 1924 to consider and act upon offers to purchase the property. ${ }^{194}$

The mining titles for Chivor 1 and 2 and the related land ownership were sold on or about August 23, 1924, to the recently formed U.S. company Chivor Emerald Corporation. ${ }^{195}$ Another new entity, the Colombia Emerald Development Corporation, was then established on November 7, and the Chivor claims and land were transferred to that company in late 1924. ${ }^{196}$ Throughout these machinations, the value of stock in the Colombian Emerald Syndicate fell precipitously, dropping from 65 cents per share in June 1922 and 40 cents in December 1922 to 5 cents in April 1923 and 1 cent in December 1923. ${ }^{197}$ The downward spiral continued thereafter, and the value was reported in 1925 at $\$ 1$ for 600 shares. ${ }^{198}$
With his employer's demise, Klein returned to Germany and over the following months established his own company in Idar in 1924, focused on the emerald trade. ${ }^{199}$ He decided to travel to Colombia once again in March 1925.200 At that time, the sale of Colombian emeralds was still strictly controlled by the government, with the only authorized channel being through the firm Rosenthal in Paris. Klein's aim was to obtain a similar authorization under which emeralds could also be sold to him directly or to a partner company. After intensive negotiations with Colombian officials, Klein was hired by the government as an evaluator for rough emeralds in Paris, in cooperation with the Colombian government's representative in the city, J.M. Arango. ${ }^{201}$ Klein was never again active as a miner in Colombia, but remained at the center of the emerald trade. Several trips to Colombia in the second half of the 1920s and the early 1930s reflect his ongoing involvement.

${ }^{186}$ File Eugene Brossard, List of United States Citizens, Arriving at Port of New York, July 1923, MyHeritage.com.

${ }^{187}$ Jewelers' Circular, Vol. 86, No. 10 (1923), p. 83; The Wall Street Journal, April 5, 1923, p. 14; The Cumulative Daily Digest of Corporation News, No. 2 (1923), pp. 142-143.

${ }^{188}$ The Wall Street Journal, April 5, 1923, p. 14; The Cumulative Daily Digest of Corporation News, No. 2 (1923), p. 142; Jewelers' Circular, Vol. 86, No. 10 (1923), p. 83.

${ }^{189}$ The Wall Street Journal, April 5, 1923, p. 14; The Cumulative Daily Digest of Corporation News, No. 2 (1923), pp. 142-143; Jewelers' Circular, Vol. 87, No. 22 (1923) p. 91.

${ }^{190}$ Jewelers' Circular, Vol. 87, No. 22 (1923), p. 91; The Cumulative Daily Digest of Corporation News, No. 4 (1923), p. 118.

${ }^{191}$ Jewelers' Circular, Vol. 86, No. 10 (1923), p. 83; Jewelers' Circular, Vol. 87, No. 22 (1923), p. 91.

${ }^{192} \mathrm{~A}$ company based in Idar, Germany, owned by August Klein and his brother-in-law August Hahn.

${ }^{193}$ The Cumulative Daily Digest of Corporation News, No. 2 (1923), p. 143; No. 3 (1923), p. 125.

${ }^{194}$ The Cumulative Daily Digest of Corporation News, No. 1 (1924), p. 164.

${ }^{195}$ The Cumulative Daily Digest of Corporation News, No. 3 (1924), p. 150, 161.

${ }^{196}$ The Cumulative Daily Digest of Corporation News, No. 4 (1924), pp. 209, 222; Winkler, 1928; Rainier, 1929, 1931.

${ }^{197}$ The Buffalo Enquirer, June 30, 1922, p. 5; The Baltimore Sun, December 30, 1922, p. 11; Democrat and Chronicle, April 27, 1923; The Tampa Tribune, December 14, 1923, p. 15. Additional details charting stock values can be traced through issues of Investor \& Trader published in 1922 and 1923.

${ }^{198}$ Engineering and Mining Journal-Press, 21 (1925), p. 999.

${ }^{199}$ Carola Kroll (granddaughter of Fritz Klein), pers. comm., 2017.

${ }^{200}$ Klein traveled via the port of Hull in Great Britain to Santa Marta in Colombia. https://www.findmypast.co.uk/Colombia. Findmypast.co.uk ${ }^{201}$ J.M. Arango was nominated General Consul of Colombia in Paris in March 1925 and was responsible for the selling of emeralds to Rosenthal. Diario Oficial (Colombia), 61, No. 19862 (1925), p. 519. 
TABLE 4. History of Chivor, 1880-1925.

\begin{tabular}{|c|c|}
\hline Date & Events in Colombia, Germany, or the United States \\
\hline 1880 s & Search for and rediscovery of old native and Spanish tunnels by F. Restrepo \\
\hline March 1889 & Mining titles for Chivor 1 and 2 are granted to F. Restrepo, E. González, B. Escobar, and Núñez \& Compañía \\
\hline August 1896 & F. Restrepo and L. Correa are referred to as the mine owners; E. González declares the Chivor mines "abandoned" \\
\hline February 1898 & Transfer of the mining titles to E. González \\
\hline August 1898 & Formation of a company by F. Restrepo and three companions; transfer of the mining titles to the company \\
\hline 1898-1899 & Cleaning of former tunnels and repair of water channels at the mine by F. Restrepo \\
\hline 1899-1909 & Numerous sales of shares involving different shareholders take place \\
\hline 1902 & First publications by the British Vice-Consul S. Dixon mentioning the rediscovery of Chivor \\
\hline August 1904 & The five principal shareholders buy land from A. Acosta \\
\hline December 1904 & $\begin{array}{l}\text { Three additional claims near Chivor } 1 \text { and } 2 \text { are registered for the Triunfo de Chivor, Paz de Chivor, and } \\
\text { Esperanza de Chivor mines, with F. Restrepo, C. Dixon, and H. Campo named as co-owners of the three titles }\end{array}$ \\
\hline 1905-1906 & C. Dixon attempts but fails to sell the three additional mines \\
\hline February 1912 & Preliminary option contract between F. Klein, H. Span, and the mine owners \\
\hline June 1912 & Formalized option contract with the mine owners; F. Klein and F. Restrepo start mining at Chivor \\
\hline End of 1912 & A. Klein joins the miners at Chivor \\
\hline March 1913 & F. Klein and F. Restrepo travel to Germany; A. Klein remains at Chivor \\
\hline July 1913 & Option contract with F. Klein is extended by Klein's lawyer \\
\hline November 1913 & F. Restrepo leaves Germany for Colombia \\
\hline December 1913 & F. Klein's option contract is extended again \\
\hline February 1914 & Formation of the "Syndikat El Chivor"; F. Klein and R. Scheibe leave Germany for Colombia \\
\hline April 1914 & R. Scheibe begins evaluation of Chivor; Restrepo becomes ill and dies at Guateque \\
\hline August 1914 & R. Scheibe finishes the evaluation of Chivor; outbreak of World War I \\
\hline End of 1914 or early 1915 & F. Klein leaves Colombia for Germany \\
\hline 1915-1916 & C. Dixon again fails to sell the three additional mines \\
\hline April 1918 & Option contract between W.E. Griffiths, C.K. MacFadden, and the mine owners \\
\hline June 1918 & Formation of the "Colombian Emerald Syndicate, Ltd."; N.W. Ross becomes president \\
\hline July or August 1919 & F. Klein and his wife leave Germany for Colombia \\
\hline August 1919 & Second option contract between W.E. Griffiths, C.K. MacFadden, and the mine owners \\
\hline December 1919 & Purchase of Chivor 1 and 2 by W.E. Griffiths and C.K. MacFadden \\
\hline By early 1920 & C. Dixon serves as Colombian manager for the "Colombian Emerald Syndicate, Ltd." \\
\hline By September 1920 & C.K. MacFadden becomes president of the Colombian Emerald Syndicate, Ltd., succeeding N.W. Ross \\
\hline Fall 1920-Spring 1921 & F. Klein serves as head of mining operations at Chivor \\
\hline December 1920 & 632 ct "Patricia" emerald is found and sent to New York \\
\hline June-December 1921 & C. Dixon serves as head of mining operations at Chivor \\
\hline September 1921 & C.K. MacFadden resigns as president and is succeeded by J.A. Arroyo \\
\hline June-July 1922 & C. Dixon travels to New York and presumably meets with company officials to discuss further activities at Chivor \\
\hline Summer 1922-1923 & F. Klein again serves as head of the mining operations at Chivor \\
\hline October 1922 & J.A. Arroyo is succeeded by J.J. Paris \\
\hline By April 1923 & An involuntary bankruptcy petition is filed in New York against the "Colombian Emerald Syndicate, Ltd." \\
\hline August 1924 & Properties are sold to the "Chivor Emerald Corporation" in a bankruptcy sale \\
\hline End of 1924 & Properties are transferred to the "Colombia Emerald Development Corporation" \\
\hline
\end{tabular}




\section{LEGENDS AND REALITY: KLEIN AND RESTREPO}

The present authors have endeavored to describe the events between 1880 and 1925 to the extent corroborated by contemporaneous primary documents, without filling gaps with dramatizations and apparent fabrications, some of which have been repeated so often as to become accepted "facts." Also, no effort has been made to explain the origin of these discredited or unverified views. Consequently, the story given here leaves various points open, waiting for future closure through discovery of further records, whether in Colombian archives or elsewhere. A few of these lingering ambiguities and the milieu in which they arise may be highlighted as follows.

Klein's 1941 memoir describes in a lively way his travels in South America, always connected with the pursuit of new gem deposits. It went to press in the middle of World War II and was geared toward a circle of readers interested in gemstones and the "adventures" associated with their discovery, mining, and trading. The book was not intended to be a historical document, consistent in all aspects with the rather complex and vacillating legal situation in Colombia, but was written for the entertainment of the interested reader.

Notably, the book was penned after an interval of almost 30 years, in terms of events before 1915, and nearly 20 years, based on the events after 1918. It is not known what contemporaneous documents and records were available to Klein when drafting the original manuscript or to what extent such manuscript was edited by the publisher or elsewhere, much less the expertise or awareness of those involved in the editorial process. A degree of liberality with facts is evidenced by the statement on the back cover of the 1941 edition referring to "drill holes that produced surprising results," although no underground mining activities or their results were mentioned in the pages.

Looking at the chronology of events (see table 4), it can be seen that actual developments in Germany and Colombia, especially regarding the acquisition of Chivor, formed a rough framework for the story told by Klein. This background was supplemented and embellished in some places and even substantially dramatized in others. For instance, the purported one-and-a-half-year search for the first emeralds in Chivor, Restrepo's death in 1914, and the "fight" for the mine with the American competitors in 1919 are all illustrative of the tendency to sensationalize.
Nonetheless, Klein did recount a large number of details that have been verified by contemporaneous materials, particularly concerning travel arrangements and individuals involved. The names offered for ships by which he journeyed between Germany, Colombia, and the United States have been corroborated by manifests, contracts, or letters, and many persons are accurately named and characterized, aside from minor spelling errors (e.g., the Colombian Emerald Syndicate's attorney Uribe-Holguin and Klein's lawyer Cadavid in Bogotá). On the other hand, some key figures are inexplicably absent or given a much diminished role. Stauch, a principal investor in the German group, is missing, and Klein's brother-in-law Jäckh is given little credit for his crucial influence in obtaining protection for Klein to return to Colombia in 1911 and in facilitating contact with potential investors such as Schacht. The name of his own brother August, who spent nearly two years at Chivor, is never mentioned.

Further complicating the situation created by the dramatized version of events is the problem of gaps in the historical record. Regarding Restrepo, for example, certain aspects of his activities are clear, while others are unexplained. Materials found to date are silent as to his partner Correa's involvement in the search for the forgotten Chivor mines in the 1880s; the reasons why the mining titles were twice transferred, first from Restrepo and three partners to Restrepo and Correa between 1889 and 1896, and later from Restrepo and Correa to González between 1896 and 1898; and the rationale for González shortly thereafter in 1898 to form a new entity in partnership with Restrepo and the other two original title applicants. Restrepo's activities during several largely silent periods and his involvement in a range of other ventures, such as farming and the coffee trade, ${ }^{202}$ are equally obscure.

The record is likewise deficient as to the dealings of the Colombian Emerald Syndicate, including Dixon's mining activities for the company, the circumstances that led to Klein's employment simultaneously with Dixon during one interval, and the reasons precipitating the 1923 bankruptcy. Thus the story, and the search, continues.

${ }^{202}$ Gaceta Judicial (Colombia), 20 (1911), pp. 49-57. 


\section{ABOUT THE AUTHORS}

Dr. Schmetzer is an independent researcher living in Petershausen, near Munich, Germany. Mr. Martayan is a senior geophysicist and longtime emerald aficionado residing in Paris, France. Mr. Ortiz is a mechanical engineer and emerald dealer who owns the Colombia Emerald Co., based in Bogotá, and Los Angeles, California.

\section{ACKNOWLEDGMENTS}

Documents, pictures, biographical data, and other information concerning the events of the years 1880 to 1925 described here have been provided by relatives of the persons involved, who have willingly reviewed their private records. Thanks are given especially to Ms. Iris Böhmer (granddaughter of Dorotheus Kracker von Schwartzenfeldt), Mr. Simon Hamilton (great-grandson of George Dixon), Ms. Anette Klein (granddaughter of August Klein), Mr. Michael Krafft (grandson of August Stauch), Ms. Carola Kroll (granddaughter of Fritz Klein), Mr. Eduardo Restrepo Ortega (grandson of Francisco Restrepo Escobar), Ms. Cordula Schacht (daughter of Dr. Hjalmar Schacht), and Mr. Andreas Scheibe (grandson of Prof. Robert Scheibe). Literature on the history of the gem trade in Idar-Oberstein, as well as historical and biographical data, were shared from the private archives of Mr. Dieter Jerusalem and Mr. Klaus Eberhard Wild; biographical data from the Idar-Oberstein city archive was supplied by Mr. Manfred Rauscher. In the search for the relevant files on German activities in Colombia and related biographical data, Ms. Annegret Wilke and Ms. Lucia van der Linde, Historical Archive of the German Ministry of Foreign Affairs, and Mr. Ralf Engel, German Federal Archive, assisted. Prof. Kris Lane, Tulane University, New Orleans, generously discussed his extensive research on Colombian history. The Ernst Jäckh collection at Columbia University in New York was reviewed by Ms. Andrea Blake, and files of Wm H. Müller \& Co. in the Stadsarchief Rotterdam were accessed by Mr. Martijn Verbon. Victor Castañeda and Yovanny Alba accompanied one of the authors (GM) on various expeditions to the Chivor mining area. Finally, countless other unnamed individuals and staff members at various archives, libraries, and local administrations should also be thanked here for numerous details and clues that helped in finding descendants of individuals involved and in completing the puzzle.

\section{REFERENCES}

Acosta J. (1848) Compendio histórico del descubrimiento y colonización de la Nueva Granada en el siglo décimo sexto. Imprenta de Beau, Paris.

Aguado P. de, Fr. (1906) Recopilación Historial. Imprenta Nacional, Bogotá.

Aguilar F.C. (1884) Ligero estudio sobre las minas de Méjico y Colombia. Anales de la Instrucción Pública en los Estados Unidos de Colombia, Vol.7, pp. 493-528.

Ancizar M. (1853) Peregrinación de Alpha: por las provincias del norte de la Nueva Granada en 1850 y 51. Imprenta de Echeverria Hermanos, Bogotá.

Anderton R. (1953) Tic-Polonga. Doubleday, New York. (1954) Tic-Polonga. Museum Press Limited, London.

Annual report on Colombia for the year 1913. In: Philip G., Ed., British documents on foreign affairs - reports and papers from the Foreign Office Confidential print. Part I, from the mid-nineteenth century to the First World War. Series D, Latin America, 1845-1914, published 1992, pp. 182-193.

Atuesta D. (1899) Informe relativo al levantamiento de los planos y mensura de los terrenos de las minas de esmeraldas de propiedad de la nación. Imprenta Nacional, Bogotá.

Bermúdez J.A. (1966) Antonio José Cadavid. Revistas Universidad Pontificia Bolivariana, Vol. 28, No.100, pp. 347-354.

Brisson J. (1899) Viajes por Colombia en los años de 1891 á 1897. Imprenta Nacional, Bogotá.

Brock F.W. (1929) Investment pitfalls. Oral Hygiene, Vol. 19, pp. 789-795.

Bullman C. (1892) The Mining Laws of the Republic of Colombia. The Scientific Publishing Company, New York.

Bürger O. (1919) Reisen eines Naturforschers im tropischen Südamerika. Dieterich'sche Verlagsbuchhandlung, Leipzig.

Cadavid A.J. (1913) En defensa del derecho de propiedad. Imprenta de La Luz, Bogotá.

Calvo Perez B. (1992) Minas y minerales de Iberoamérica. IGME, Madrid.

Canova L.J. (1921) Legend of the Discovery of Emeralds in the Colombian Andes. Colombian Emerald Syndicate, Ltd., New York.

Céspedes Cubides J.E. (2017) Reminiscencias de la Guerra de los Mil Días. Descripción y análisis del régimen de responsabili- dad extracontractual del Estado, con posterioridad a la Guerra Civil de 1899 a 1902. Universidad del Rosario, Facultad de Jurisprudencia, Maestria en derecho administrative, Bogotá.

Díaz C.A. (1967) Páginas de Historia Colombiana. Recuerdo de Antonio José Cadavid. Imprenta del Departamento, Bucaramanga.

Dixon S.S. (1902) Mining in Colombia in 1901. The Mining Journal, Vol. 72, p. 429.

Domínguez R.A. (1965) Historia de las esmeraldas de Colombia. Gráficas Ducal, Bogotá.

Eder P.J. (2017) A banker invites other bankers to make money in Colombia. In Farnsworth-Alvear A., Palacios M., and Gómez López A.M., Eds., The Colombia Reader: History, Culture, Politics. Duke University Press, Durham and London, pp. 457463.

Enciclopedia universal ilustrada europeo-americana: Apéndice 2 (BED-CEQ). (1931) Espasa-Calpe, Madrid.

Esquivel Triana R. (2001) Fuentes para la historia agraria e industrial de la provincia de Neiva 1778-1938. Memoria y Sociedad: Revista del Departamento de Historia y Geografía, Vol. 5, No. 9, pp. 61-88.

Fals-Borda O. (1955) Odyssey of a sixteenth-century document Fray Pedro de Aguado's "Recopilacion Historial." The Hispanic American Historical Review, Vol. 35, No.2, pp. 203-220.

Falz E. (1939) Von Menschen und Edlen Steinen. Selbstverlag, Idar.

Fernández Piedrahita L. (1881) Historia general de las conquistas del nuevo reino de Granada. A la S.C.R.M. de D. Carlos Segundo Rey de las Españas y de las Indias. Imprenta de Medardo Rivas, Bogotá.

Fortaleché D., Lucas A., Muyal J., Hsu T., Padua P. (2017) The Colombian emerald industry: Winds of change. $G \uplus G$, Vol. 53, No. 3, pp. 332-358, http://dx.doi.org/10.5741/GEMS.53.3.332

Francis J.M. (2007) Invading Colombia. The Pennsylvania State University Press, University Park, PA.

Friede J. (1964) Fray Pedro Aguado, con Ocasión del 450 Aniversario de su Nacimiento. The Hispanic American Historical Review, Vol. 44, No. 3, pp. 382-389.

Gamba F.P. (1913) Emerald fields of Colombia. Mining and Scientific Press, Vol. 107, p. 345.

Geografía económica de Colombia, Tomo III: Boyacá, 1936. Bo- 
gotá, Contraloría General de la República.

Gilles V.A. (1930) Geology of the Chivor emerald mine. In Buis, O. and Bronkie W.F., Eds., Guide Book to the Geology of the Chivor Emerald Mine. Colombian Society of Petroleum Geologists and Geophysicists, published 1966, pp. 5-18.

González E. (1911) Esmeraldas de las minas de Muzo y Coscuez. Imprenta Moderna, Bogotá.

Groot J.M. (1869) Nueva Granada, escrita sobre documentos auténticos. Imprenta a cargo de Foción Mantilla, Bogotá.

Jäckh E. (1954) Der Goldene Pflug. Deutsche Verlags-Anstalt, Stuttgart.

Johnson P.W. (1959) The emeralds of Chivor today. Lapidary Journal, Vol. 13, No. 4, pp. 516-524.

(1961) The Chivor emerald mine. Journal of Gemmology, Vol. 8, No. 4, pp. 126-152.

Klein F. (1941) Smaragde unter dem Urwald. Oswald Arnold Verlag, Berlin.

(1951) Smaragde unter dem Urwald. Selbstverlag, IdarOberstein.

Kopper C. (2006) Hialmar Schacht: Aufstieg und Fall von Hitlers mächtigstem Bankier. Deutscher Taschenbuch Verlag, Munich.

Lane K. (2010) Colour of Paradise: The Emerald in the Age of Gunpowder Empires. Yale University Press, New Haven and London.

Latham E.B. (1911) The newly discovered emerald mines of "Somondoco." The School of Mines Quarterly, Vol. 32, No. 3 , pp. 210-214.

Legrand C. (1988) Colonización y protesta campesina en Colombia (1850-1950). Universidad Nacional de Colombia, Bogotá.

Levinson O. (2007) Diamanten im Sand: Das wechselvolle Leben von August Stauch. Kuiseb Verlag, Windhoek.

MacFadden C.K. (1920) Petroleum in Colombia. The Colombian Review, Vol. 1, pp. 36-38.

Martin de Retana J.M., Ed. (1990) El gran libro de la esmeralda. Editorial la Gran Enciclopedia. Vasca, Bilbao.

Martínez F.A. (1950) Don Emiliano Isaza. Thesaurus: Boletín del Instituto Caro y Cuervo, Vol. 6, No. 2, pp. 271-278.

Martínez Covaleda H.J., Martínez Covaleda R. (1996) Economía y región: aproximación a la historia del siglo XIX en el Huila. In Tovar Zambrano, B., Ed., Historia general de Huila, Vol. 3, Academia Huilense de Historia, pp. 15-76.

Montaña F. (1915) Renta de esmeraldas: Apuntes fiscales. The Salesian Press, London.

Moore T.P., Wilson W.E. (2016) The emerald mines of Colombia. The Mineralogical Record, Vol. 47, No. 1, pp. 5-68.

Moreno F.A. (1772) Estado del Virreinato de Santafé, Nuevo Reino de Granada. Anales de la Universidad Nacional de los Estados Unidos de Colombia, Vol. 4, No. 19, 1870, pp. 34-96.

Moreno Calderón D. (2011) Cronología de la historia del Estado Soberano del Tolima. HUILA, Vol. 14, No. 62, pp. 29-67.

Ochoa Ortiz F. (1921) Immigration into Ecuador. The Republic of Ecuador, Vol. 1, No. 1, pp. 24-25.

Plaza J.A. (1850) Memorias para la historia de la Nueva Granada desde su descubrimiento hasta el 20 de julio de 1810. Imprenta del Neo-Granadino, Bogotá.

Pogue J.E. de (1917) The emerald deposits of Muzo, Colombia. Transactions of the American Institute of Mining Engineers, Vol. 55, pp. 910-934.
Quintero A., Centeno R. (2007) Hacendados, comerciantes y negociantes de Neiva a finales del siglo XIX: actores, capitales, sociedades y negocios. Universidad Surcolombiana, Neiva.

Rainier P.W. (1929) The Chivor-Somondoco emerald mines of Colombia. The American Institute of Mining and Metallurgical Engineers, Technical Publication No. 258.

- (1931) The Chivor-Somondoco emerald mines of Colombia. Transactions of the American Institute of Mining and Metallurgical Engineers AIME, Vol. 96, pp. 204-223.

(1933) Las minas de esmeraldas de Muzo y Coscuez. Internal Report printed 1958 in Boletín de Minas Vol. 5, Nos. 5657 , pp. 10-19.

_ (1942) Green Fire. Random House, New York.

Rauff H. (1926) Robert Scheibe †. Gedächtnisreede. Jahrbuch der Preußischen Geologischen Landesanstalt zu Berlin, Vol. 47, No. 2, pp. 63-71.

Rausch J.M. (2014) Colombia and World War I: The Experience of a Neutral Latin American Nation during the Great War and its Aftermath, 1914-1921. Lexington Books, Lanham, Maryland.

Scheibe R. (1916) Minas de Muzo. Informe del Ministro de Hacienda (Colombia) 1916, pp.181-198.

- (1922) Informe del doctor Robert Scheibe sobre la mina de Muzo. Informe del Ministro de Hacienda al Congreso de 1922, pp. $99-112$.

(1926) Die Smaragdlagerstätte von Muzo (Kolumbien) und ihre nähere Umgebung. Neues Jahrbuch für Mineralogie, Beilagenband 54, Abt. B, pp. 417-447.

Schuhmacher H.A. (1875) Ueber die Columbischen Smaragden. Zeitschrift der Gesellschaft für Erdkunde zu Berlin, Vol. 10, pp. 38-62.

Schwarz H.F. (1953) In memory. The Explorers Journal, Vol. 31, No. 4, pp. 54-55, 64.

Simón P., Fr. (1891) Noticias historiales de las conquistas de Tierra Firme en las Indias Occidentales, Segunda Parte. Casa Editorial de Medardo Rivas, Bogotá

Singewald Q.D. (1950) Mineral resources of Colombia (other than petroleum). Geologic Investigations in the American Republics, 1949. Geological Survey Bulletin 964-B, pp. 5361.

Sinkankas J. (1981) Emerald and Other Beryls. Chilton Book Company, Radnor, Pennsylvania.

Skinner W.R. (1889-1890) The Mining Manual, Vol. 3, pp. 116-117, 333.

- (1891-1892) The Mining Manual, Vol. 4, pp. 75, 121, 341.

(1896) The Mining Manual, Vol. 8, p. 1151.

_ (1897) The Mining Manual, Vol. 9, pp. 1279-1280.

(1900) The Mining Manual, Vol. 12, p. 1190.

Strunz H. (1970) Von der Bergakademie zur Technischen Universität Berlin 1770-1970. Förderer der Berliner Fakultät für Bergbau und Hüttenwesen e.V., Berlin.

Torres del Río C.M. (2015) Colombia siglo XX: desde la Guerra de los Mil Días hasta la elección de Álvaro Uribe. Editorial Pontificia Universidad Javeriana, Bogotá.

Weldon R., Ortiz J.G., Ottaway T. (2016) In Rainier's footsteps: Journey to the Chivor emerald mine. $G \uplus G$, Vol. 52, No. 2, pp. 168-187, http://dx.doi.org/10.5741/GEMS.52.2.168

Winkler M. (1928) Investments of United States Capital in Latin America. World Peace Foundation, Boston. 